\title{
Regulating the Energy Transition: FERC and Cost-Benefit Analysis
}

\author{
Avi Zevin
}

I. Introduction ................................................................... 421

II. Cost-Benefit Analysis and the Federal Energy

Regulatory Commission................................................... 428

A. Cost-Benefit Analysis as Applied by Federal Agencies 428

B. FERC Should Shift Course and Embrace Cost-Benefit

Analysis....

C. The Case for Cost-Benefit Analysis at FERC ................ 436

1. Improving Social Welfare ........................................... 436

2. Transparency and Accountability............................. 439

3. Anticipating Executive Branch Mandates................ 444

4. Limiting Legal Risk ................................................. 446

D. FERC's Decisions Are Amenable to Cost-Benefit

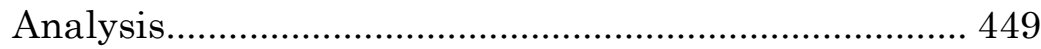

III. Wholesale Electric Market Rules .................................. 453

A. FERC's Role and Current Approach.............................. 453

1. FERC's Initial Transformation of the Electric

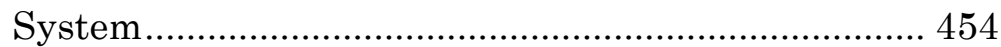

2. Cost Benefit Analysis in a Supporting Role.............. 455

3. FERC's Current Approach to Policing Electric Market Rules .............................................................. 459

B. FERC Should Adopt an Expanded Cost Benefit

Requirement ............................................................ 462

C. Statutory Authority ................................................... 465

* Affiliated Scholar, Institute for Policy Integrity at New York University School of Law. This article was prepared in the author's personal capacity and all views expressed herein are solely his own. The author would like to thank Norman Bay, Sylwia Bialek, Matthew Christiansen, Bethany Davis Noll, Justin Gundlach, Max Minzner, and Richard L. Revesz for their insights and comments.

(C) 2020 Avi Zevin. This article is distributed under the terms of the Creative Commons Attribution 4.0 International License provided the original author and source are credited. For the complete terms of the license please see: https://creativecommons.org/ licenses/by/4.0/. 
1. Cost-Benefit Analysis and the Just and Reasonable Standard

2. The Scope of Costs and Benefits FERC May Consider 469

D. Applying Cost-Benefit Analysis ................................... 477

1. Categories of Costs and Benefits ............................. 477

a. Efficiency Effects ................................................. 477

b. Distribution of Costs and Benefits .......................... 478

c. Administrative Costs ............................................... 478

d. Reliability (and Resilience) ..................................... 479

e. Environmental Costs and Benefits ........................ 479

2. Economic Tools ....................................................... 480

a. Electricity Market Modeling................................... 480

b. Air Pollution Damage Modeling............................. 481

c. Resilience Modeling................................................... 482

E. Additional Examples of Cost-Benefit Analysis in Electric System Regulation ............................................ 483

IV.Natural Gas Pipeline Certificate Approvals ..................... 487

A. FERC's Role and Current Approach.............................. 487

1. FERC's Role Overseeing Construction and Operation of Natural Gas Pipelines ......................... 487

2. Cost-Benefit Analysis in a Supporting Rule ............. 488

3. FERC's Constrained Approach to Approving Natural Gas Infrastructure..................................... 490

B. FERC Should Adopt an Expanded Cost Benefit

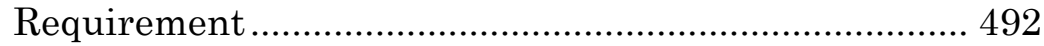

C. Statutory Authority ..................................................... 498

1. Cost-Benefit Analysis and the Public Convenience and Necessity Standard............................................. 498

2. The Scope of Costs and Benefits FERC May

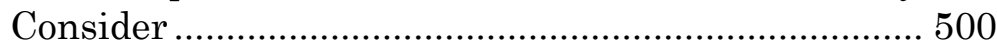

D. Applying Cost-Benefit Analysis ................................... 504

1. Categories of Costs and Benefits to Consider ............ 504

a. Expanding Availability and Lowering Price of Natural Gas ......................................................... 504

b. Construction and Operational Costs ..................... 507

c. Landowner and Community Costs........................... 507

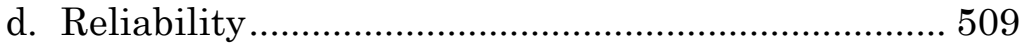

e. Environmental Costs and Benefits ........................ 510

2. Economic Tools ............................................................ 514 


\section{INTRODUCTION}

Over the past thirty-five years, presidents and courts have pushed administrative law and the regulatory process towards what a number of prominent commenters have called a "costbenefit state." 1 Under the cost-benefit state, administrative agencies advance regulation only after considering the costs and benefits of potential policy options, and select a solution in which the benefits justify the costs. By using cost-benefit analysisthe systematic evaluation and, where possible, quantification of all of the costs and benefits of an agency's action-agencies are able to make more informed and rational decisions, transparently weigh tradeoffs, and provide the public with relevant information regarding what to expect from regulation.

The move towards a cost-benefit state has accelerated in recent years. The use of cost-benefit analysis to inform regulatory decisions has primarily been advanced by the executive branch, reaffirmed and institutionalized by presidents of both political parties over multiple decades. 2 These requirements were initially met with some skepticism in the courts. 3 However, the courts have more recently embraced the consideration and weighing of costs and benefits as an integral part of agency decision making. 4 And while federal agencies

1 Cass R. Sunstein, The Cost-Benefit State: the Future of Regulatory Protection (2002). See also John D. Graham \& Paul R. Noe, A Paradigm Shift in the Cost-Benefit State, REG. REV. (April 26, 2016), https://www.theregreview.org/2016/04/ 26/graham-noe-shift-in-the-cost-benefit-state/ [https:/perma.cc/YUU4-YAW4]. 2 See Exec. Order No. 12,291 §§ 2(b), 3, 46 Fed. Reg. 13,192, 13,193 (Feb. 19, 1981); Exec. Order No. 12,866, 58 Fed. Reg. 51,735 (Sep. 30, 1993); OfFICE OF MGMT. \& BudGET, Circular A-4: REgulatory ANAlysis (2003) [hereinafter Circular A-4]; Exec. Order No. 13,563, 76 Fed. Reg. 3821 (Jan. 21, 2011).

3 See, e.g., Whitman v. Am. Trucking Ass'ns, Inc., 531 U.S. 457, 470-71 (2001) (holding that, absent a "clear" direction to do so, the provisions of the Clean Air Act require EPA to establish National Ambient Air Quality Standards without consideration of costs); Am. Textile Mfrs. Inst., Inc. v. Donovan, 452 U.S. 490, 510 (1981) ("When Congress has intended that an agency engage in cost-benefit analysis, it has clearly indicated such intent on the face of the statute.").

4 Se, Caroline Cecot \& W. Kip Viscusi, Judicial Review of Agency Benefit-Cost Analysis, 22 Geo. MAson L. Rev. 575, 585-87, 609-17 (2015) (discussing recent Supreme Court cases permitting cost-benefit analysis and thirty-eight appellate court cases that reviewed agency use of cost-benefit analysis). See also Michigan v. EPA, 135 S. Ct. 2699, 
under President Trump appear less committed to a vision of regulation where action is taken based on rigorous analysis of costs and benefits, 5 the courts have continued to reinforce the importance of cost-benefit analysis. 6

Most independent agencies have not yet embraced the costbenefit state. The executive orders that have spurred executive branch agencies to analyze the costs and benefits of proposed regulations have explicitly left out independent agencies, 7 and few use cost-benefit analysis voluntarily. 8 One such independent regulatory agency is the nation's primary energy regulator, the Federal Energy Regulatory Commission ("FERC"). FERC is a five-member independent regulatory agency with two primary responsibilities: (1) the economic regulation of the wholesale sales of electricity and natural gas, and of the interstate transportation of that electricity and gas through transmission lines and pipelines; and (2) the permitting of certain types of energy projects-interstate natural gas pipelines and hydroelectric dams - that FERC determines are in

2706-07 (2015) (holding unlawful an EPA finding that regulating hazardous air pollution from power plants was "appropriate and necessary" because EPA made that finding without considering the costs of regulation); Mingo Logan Coal Co. v. EPA, 829 F.3d 710, 730 (D.C. Cir. 2016) (Kavanaugh, J., dissenting) (considering the costs of a repeal "is common sense and settled law").

5 See Richard Revesz, E.O. 12866-25th Anniversary Remarks, Geo. WASH. Reg. Stud. CTR. (Oct. 9, 2018), https://regulatorystudies.columbian.gwu.edu/eo-12866-25thanniversary-remarks [https://perma.cc/WHD5-CD4E]. See also Dan Farber, The End of the Cost-Benefit State?, LEGAL PlaneT (Feb. 27, 2017), http://legalplanet.org/2017/02/27/the-end-of-the-cost-benefit-state/ [https://perma.cc/GW2L-LD7U]. ${ }_{6}$ E.g., California v. U.S. Bureau of Land Mgmt., 277 F. Supp. 3d 1106 (N.D. Cal. 2017) (vacating a delay of a regulation limiting waste of natural gas produced on federal lands because, in part, the agency had arbitrarily failed to consider the forgone benefits of the rule).

7 Exec. Order No. 12,291 § 1(d), 46 Fed. Reg. 13,193, 13193 (Feb. 7, 1981); Exec. Order No. 12,866 § 3(b), 58 Fed. Reg. 51,735 (Sep. 30, 1993); Exec. Order No. 13,563 § 7(a), 76 Fed. Reg. 3821, 3822 (Jan. 21, 2011).

8 Arthur Fraas \& Randall Lutter, On the Economic Analysis of Regulations at Independent Regulatory Commissions, 63 ADMIN. L. REV. 213, 215 (2011) (finding that analysis supporting regulatory action conducted by independent agencies is limited to "the minimum required by statute"); Richard L. Revesz, Cost-Benefit Analysis and the Structure of the Administrative State: The Case of Financial services Regulation, 34 YALE J. REG. 545, 560-61 (2017) (discussing the failure of independent agencies to conduct adequate cost-benefit analysis). 
the public interest.9 FERC does not generally use cost-benefit analysis as a tool for fulfilling these responsibilities.10

FERC has not always been so hostile to its use, however. During the last time of major transition in the energy system, FERC recognized the importance of weighing broad categories of costs and benefits when fulfilling its responsibilities. Under the traditional model in place from the 1930s, when Congress passed the Natural Gas Act ("NGA") and Federal Power Act ("FPA"), until the 1990s, FERC set the rates and conditions for sales of electricity, natural gas, and associated transmission service between monopoly utilities. However, thirty years ago, changes in technology and regulatory philosophy led FERC to refashion its role to become a regulator of competitive markets, responsible for crafting rules that rely on market forces to reliably provide service at efficient prices, enable competition among diverse suppliers, limit market power, and place risk (and reward) with investors rather than captive customers. For electricity, FERC also encouraged the formation of independent grid operators, called regional transmission organizations ("RTOs"), 11 which integrate and manage both the physical operation of the bulk electric system and the organized markets that determine which generators will supply electric demand (or "load") in a given interval. At the start of this transition, FERC turned to cost-benefit analysis to help inform its decision making. FERC's single most important electricity sector regulation-Order 888 , which helped restructure the electricity system-included a robust cost-benefit analysis. 12 As did its order encouraging the formation of RTOs, 13 and its evaluation of

\footnotetext{
9 Lawrence R. Greenfield, An Overview of the Federal Energy Regulatory COMmission AND Federal REgulation of Public Utilities 3-4, 10 (2018).

10 See Part II(b), infra.

11 FERC has established two models for central management of the electric grid: independent system operators (ISOs) and RTOs. The legal and practical distinctions between ISOs and RTOs are minor and not relevant for the purposes of the issues discussed herein. Therefore, for simplicity, I refer generally to central grid operators as RTOs.

12 Promoting Wholesale Competition Through Open Access Non-Discriminatory Transmission Services by Public Utilities, Order No. 888, FERC Stas. \& Regs., ๆ 31,036, at 31,860 (1996) [hereinafter Order No. 888].

${ }_{13}$ Regional Transmission Organizations, Order No. 2000, 89 FERC 9 61,285, at P 3 (Dec. 20, 1999) [hereinafter Order No. 2000].
} 
specific RTO proposals.14 But FERC has not followed that up with the consistent use of cost-benefit analysis, even as FERC's most important actions shifted from approving specific financial contracts among market participants to setting the rules of the game.15

In 1999, FERC issued a Policy Statement clarifying its role in the approval of pipeline projects.16 This Policy Statement was spurred by FERC's recognition that changes in the gas industry brought about by its deregulatory efforts described above would result in expanded demand for natural gas infrastructure. And, in light of those changes, FERC included language suggesting it would fulfill its responsibility of permitting natural gas infrastructure by weighing costs and benefits imposed on market participants and the general public. 17 But despite paying lip service to the language of cost-benefit analysis, FERC has, over time, moved further away from its commitment to weigh costs and benefits-instead relying on limited evidence such as contractual commitments to purchase natural gas as evidence of the desirability of projects. 18 And FERC has generally ignored one of the most important costs of natural gas infrastructure: climate change.19

This Article argues that now is an apt time for FERC to shift course and embrace the cost-benefit revolution. The energy system is again in a time of profound transition.20 Technological advances have substantially reduced the cost of new energy production resources, which have different benefits and limits as compared to legacy options. For example, wind turbines and

14 See Joseph H. Eto \& Douglas R. Hale, A Review of Recent RTO Benefit-Cost Studies: TOWARD MORE COMPREHEnsive Assessments OF FERC EleCtRICITY Restructuring Policies (2005), [hereinafter RTO CBA RePORT] (discussing limited use of cost-benefit analysis to evaluate the formation of RTOs).

15 As discussed more infra, FERC sets the rules of the game using both rulemakings that apply industry-wide and adjudication that approve or direct changes for individual RTOs.

${ }_{16}$ Certification of New Interstate Natural Gas Pipeline Facilities, 88 FERC \ 61,227 (1999) [hereafter 1999 Policy Statement].

17 Id. at 61,737 (describing FERC's evaluation of pipeline certificate applications as weighing benefits and costs).

18 National Fuel Supply Corp., 158 FERC I 61,145, at P 3 (2017) (Bay, Comm'r, separate statement).

19 See Richard Glick \& Matthew Christiansen, FERC and Climate Change, 40 EnERGY L.J. 1, 42 (2019).

${ }_{20} I d$. at 7-14 (outlining evidence and implications of the energy transition). 
solar panels are now cost-competitive with coal and natural gas.21 These sources produce power at zero marginal cost but only intermittently, necessitating changes to electricity market design.22 Battery electric storage, which has seen costs fall $85 \%$ from 2010 to 2018, 23 can provide new grid services such as matching intermittent generation with the needs of the system, but rules will have to change to fully enable their participation in electricity markets. 24 Demand response aggregationsenabled by smart meters and internet-connected appliancesallow consumers to seamlessly reduce usage at times of peak demand, thereby lowering system costs. 25 Meanwhile, as a result of the growing recognition of the critical importance of decarbonizing the energy sector in order to meet the threat of climate change, consumers are demanding access to these clean energy options 26 and states are passing policies to retain existing zero-emitting generation while accelerating deployment of new clean energy even beyond what the market would demand on its own. 27 At the same time, new production technologies have substantially reduced the cost of natural gas, creating demand for new natural gas power plants, as well as the pipeline and export infrastructure needed to supply them.28 These power

${ }_{21}$ Renewable Electricity Levelized Cost of Energy Already Cheaper Than Fossil Fuels, and Prices Keep Plunging, ENERgy InNOVATION POL’Y \& TECH. (Jan. 22, 2018), https://energyinnovation.org/2018/01/22/renewable-energy-levelizedcost-of-energyalready-cheaper-than-fossil-fuels-and-prices-keep-plunging/ [https://perma.cc/L3WGTFCC].

22 DeP't of Energy, Transforming The Nation's Electricity System: The Second INSTALLMENT OF THE QER at 4-40 (2017) [hereafter QER 2].

23 Veronika Henze, Energy Storage Investments Boom as Battery Costs Halve in the Next Decade, BLOOMBERG NEW ENERGY FIN. (July 31, 2019), https://about.bnef.com/

blog/energy-storage-investments-boom-battery-costs-halve-next-decade/ [https://perma.cc/4FQS-4BGZ].

${ }_{24}$ Eric Gimon, How Market Rules are Holding Back Energy Storage, GREENTECH MEDIA (Jan. 24, 2019), https://www.greentechmedia.com/articles/read/energy-storagewholesale-market-rules [https://perma.cc/WF6C-AQT3].

${ }_{25}$ QER 2, supra note 22, at 1-26.

${ }_{26}$ David Roberts, Utilities Have a Problem: The Public Wants 100\% Renewable Energy, and Quick, VOX (Oct. 11, 2018), https://www.vox.com/energy-and-environment/2018/ 9/14/17853884/utilities-renewable-energy-100-percent-public-opinion [https://perma.cc/5EFP-DUK7].

${ }_{27}$ Farah Benahmed \& Lindsey Walter, Clean Energy Targets Are Trending, THIRD WAY (Dec. 11, 2019), https://www.thirdway.org/graphic/clean-energy-targets-are-trending [https://perma.cc/5E39-E53A].

28 Alexandra B. Klass \& Danielle Meinhardt, Transporting Oil and Gas: U.S. Infrastructure Challenges, 100 IOWA L. REV. 947, 999-1000 (2015) (discussing the growth 
plants often displace higher-emitting alternative sources of electricity and so reduce greenhouse gas emissions; 29 however, the natural gas infrastructure may make further decarbonization harder to achieve. 30

As a result, energy regulators have begun to take a broader view of their responsibilities to develop an energy system that works not just for investors and customers, but also for the broader public interest. 31 This change has the potential to affect both FERC's role as an electricity market regulator and as a permitter of energy infrastructure.32 FERC is faced with highprofile and contentious proceedings in which different stakeholders have asked for market changes that have the potential to retain uncompetitive inflexible coal-fired power plants or, alternatively, to facilitate integration of new low- and zero-emitting technologies such as wind, solar, demand response, and storage.33 FERC is also currently in the process of reevaluating its natural gas certificate policy and has requested comment on whether its policy should use economic tools to calculate and balance a broader array of costs and

of U.S. natural gas production caused by technological changes); SUSAN TIERNEY, Analysis Group, Natural Gas Pipeline Certification: Policy Considerations for A ChANGING INDUSTRY 23-24 (2017), (showing increasing usage of gas in the electric power sector); Certification of New Interstate Natural Gas Facilities, 163 FERC @ 61,042, at P 21 (2018) [hereafter Policy Statement NOI] (describing the increase in pipeline certificate applications since 2010).

29 Perry Lindstrom, EIA Expects U.S. Energy-Related CO2 Emissions to Decrease Annually Through 2021, EIA: TODAY IN ENERGY (Jan. 17, 2020), https://www.eia.gov/todayinenergy/detail.php?id=42515 [https://perma.cc/5GNR-4Q32]. 30 Michael O'Boyle, Utility Investors Risk Billions in Rush to Natural Gas: Is It A Bridge to Climate Breakdown?, FoRBEs (Mar. 4, 2020), https://www.forbes.com/sites/ energyinnovation/2020/03/04/utility-investors-risk-billions-in-rush-to-natural-gas-is-ita-bridge-to-climate-breakdown/\#f14624a50af7 [https://perma.cc/V8AA-HJGA].

${ }_{31}$ See generally Glick \& Christiansen, supra note 19, at 7-14; Jody Freeman, The Uncomfortable Convergence of Energy and Environmental Law, 41 HARV. ENVTL. L. REV. 339 (2017).

32 Glick \& Christiansen, supra note 19, at 14-16 (discussing FERC's role in the energy transition).

${ }_{33}$ Grid Resiliency Price Rule, 82 Fed. Reg. 46,940 (proposed Oct. 10, 2017) [hereinafter DOE NOPR] (Department of Energy-initiated notice of proposed rulemaking to compensate coal and nuclear power plants for fuel security value); Calpine Corp., v. PJM Interconnection, LLC, 163 FERC \ 61,236 (2018) (initiating a proceeding to consider reform of PJM capacity market in order to mitigate effect of state carbon policies); NEW York ISO, IPPTF CARBON PRICING PROPOSAL (Dec. 7, 2018), (draft proposal to incorporate a price on carbon dioxide emissions directly into FERC-jurisdictional wholesale market). 
benefits of a gas infrastructure projects. 34 In both cases, FERC must balance competing interests in the brighter spotlight of the public, Congress, and the courts.

In managing this transition, a successful FERC will balance competing interests, explain its choices clearly to the public and its congressional overseers, and, ultimately, act in ways that make the American people better off. To do so, FERC would adopt, accept, or require rule changes and approve infrastructure projects that reduce emissions, maintain system reliability, and ensure affordable access to energy. Cost-benefit analysis can help FERC meet each of these objectives. Doing so will also help satisfy FERC's obligation to act in ways that are not arbitrary and capricious, 35 and that are in service of its mandate to promote the public interest; 36 accordingly, costbenefit analysis can serve as an analytical tool that will shield it from legal risk.

Use of cost-benefit analysis would not be appropriate in all circumstances. FERC issues over a thousand orders a year and requiring a formal quantification of costs and benefits for each would be impractical.37 But drawing on best-practices from other agencies, 38 FERC can establish relevant thresholds and criteria to use the tool for its most significant actions, including industry-wide rulemakings, major changes to individual RTO market rules, and approval of large infrastructure projects. A proactive decision to use cost-benefit analysis for FERC's most significant actions would be an important next step in enhancing

\footnotetext{
${ }_{34}$ Policy Statement NOI, supra note 28, at P 54 ("In determining whether there is a public need for a proposed project, what benefits should the Commission consider"); $i d$. at 57 ("should the Commission consider changing how it balances the potential use of eminent domain against the showing of need for the project"); id. at 58 ("should the Commission consider changing how it weighs a proposed project's adverse environmental impacts against favorable economic benefits to determine whether the proposed project is required by the public convenience and necessity").

35 Motor Vehicles Mfrs. Ass'n v. State Farm Mutual Auto. Ins., 463 U.S. 29, 42-43 (1983). 3616 U.S.C. $§ 824$ (a) (2018) ("It is declared that the business of transmitting and selling electric energy for ultimate distribution to the public is affected with a public interest"); 15 U.S.C. $§ 717$ (a) (2018) ("it is declared that the business of transporting and selling natural gas for ultimate distribution to the public is affected with a public interest"). ${ }_{37}$ Letter from Norman C. Bay, Chairman, FERC, to President Donald J. Trump 2 (Jan. 26, 2017), available at https://www.ferc.gov/media/headlines/2017/2017-1/01-26-17.pdf [https://perma.cc/X683-32KW] [hereinafter Norman C. Bay Letter]. 38 See Exec. Order No. 12,866 § 3(f)(1), 58 Fed. Reg. 51,735 (Oct. 4, 1993).
} 
the rigor, transparency, and accountability of its actions at this critical time of transition.

This Article proceeds in four parts. Part II begins by defining cost-benefit analysis as it is applied by federal agencies, and then explains why FERC should move away from its general refusal to employ cost-benefit analysis and embrace it as a means of evaluating the consequences of its potential decisions. Part II also provides normative reasons why FERC should deploy cost-benefit decision making, identifies limits on the use of cost-benefit analysis, and discusses the institutional capabilities that make cost-benefit a good fit for FERC. Parts II and III more deeply evaluate how cost-benefit analysis can better inform the two most important areas of FERC's decision making responsibility. Part III covers FERC's regulation of the electric system under the FPA, with a focus on FERC's approval of proposed market rule changes offered by RTOs under Section 205 and its ability to mandate changes under Section 206. Part III also briefly identifies additional areas of FERC electric system regulation that would benefit from the use of cost-benefit analysis: the establishment of minimum reliability standards and the establishment of incentives for the construction of certain types of interstate electric transmission. Part IV covers FERC regulation of the construction and operation of natural gas infrastructure projects. Each of these parts discusses FERC's current approach to decision making, analyzes FERC's legal authority to rely on cost-benefit analysis, and identifies tools that FERC can use to conduct cost-benefit analyses. Finally, Part V offers some concluding thoughts.

\section{COST-Benefit ANALYSis AND THE FEDERAL ENERGy REGULATORY COMMISSION}

\section{A. Cost-Benefit Analysis as Applied by Federal Agencies}

Cost-benefit analysis is both a method for evaluating the expected consequences of an action under consideration and a method of decision making for choosing among potential actions.39 As a method of evaluation, cost-benefit analysis puts

39 Richard A. Posner, Cost-Benefit Analysis: Definition, Justification, and Comment on Conference Papers, 29 J. LEGAL STUD. 1153, 1153-54 (2000) (discussing the definition of cost-benefit analysis along two axes: as an evaluative tool and as a decision tool). 
particular emphasis on the formalized use of science and economics to identify the expected effects-both good and badof a particular action. Those effects can then be compared on equal terms-generally "monetized" as dollars and cents. 40 Cost-benefit analysis as a method of decision making generally involves comparing the costs and benefits of a number of alternative actions, and picking an option where the benefits exceed the costs by the largest amount.

The specific contours of how agencies perform and use costbenefit analysis is informed largely by a series of executive orders and guidance documents dating back to the early 1980s. President Reagan's 1981 Executive Order 12,291 implemented a shift toward the systematic and coordinated use of cost-benefit analysis by federal agencies. 41 A little over ten years later, President Clinton issued a new executive order, Order 12,866, which established a set of requirements that reaffirmed the broad goals and approach of the prior executive order, though with some changes in detail and emphasis. Order 12,866 has been embraced by Presidents George W. Bush,42 Obama,43 and Trump,44 and continues to serve as the governing document for executive branch agency evaluation of regulations.

Under Executive Order 12,866, executive branch agenciesthat is, agencies other than independent regulatory agencies

${ }_{40}$ Monetizing costs and benefits, particularly for non-market effects such as species loss, can be difficult or impossible. See generally Cass R. Sunstein, The Limits of Quantification, 102 CALIF. L. REV. 1369, 1370-80 (2014) (discussing challenges of quantifying non-market goods and potential solutions). See also FRANK ACKERMAN \& LisA HeinZerling, Priceless (2004) (generally discussing criticisms of cost-benefit analysis). However, most of the immediate consequences of FERC's decisions, are amenable to monetization. See Part II(c)(1). Moreover, monetization, combined with qualitative analysis, can help inform agency decision-making even when not all consequences can be monetized.

41 Exec. Order No. 12,291, 3 C.F.R. pt. 127 (1981). For a more complete history of centralized regulatory review, see Regulatory Accountability Act of 2011, H.R. 3010, 112th Cong. (2011).

${ }_{42}$ Exec. Order No. 13,422, 72 Fed. Reg. 2763 (Jan. 23, 2007) (making only minor amendments to Executive Order 12,866).

43 Exec. Order No. 13,563 § 1(b), 76 Fed. Reg. 3821 (Jan. 18, 2011) (reaffirming Executive Order 12,866 and supplementing it with additional requirements such as retrospective review of existing regulations).

${ }_{44}$ Exec. Order No. 13,777 § 2(a)(ii), 82 Fed. Reg. 12,285 (Mar. 1, 2017) (directing agencies implement regulatory reform initiatives and policies including Executive Order 12,866). 
and commissions 45 -are required to identify the costs and benefits of "significant" regulations-generally, those with an estimated economic impact greater than $\$ 100$ million per year.46 When possible, agencies must find that the benefits of regulation justify the costs. 47

In 2003, the Office of Management and Budget (“OMB"), within the Executive Office of the President, issued Circular A4 , a guidance document that provides significant detail on best practices for agency cost-benefit analyses. 48 Circular A-4 explains that agency cost-benefit analyses should use economic tools to translate the effects of their actions in the common metric of dollars so that disparate effects can be compared to each other.49 But Circular A-4 also recognizes that not all costs and benefits are quantifiable or monetizable using accepted methodologies and available data.50 When existing data or valuation methodologies are insufficient, costs and benefits can be evaluated and discussed qualitatively.51 The agency can use its professional judgment to evaluate the relative importance of those non-quantified costs and benefits and act accordingly.52 Such judgment can be aided by the use of an approach called "threshold analysis" or "break even analysis," in which the agency calculates the minimum value that the non-quantified benefits (or costs) must have to yield positive (or negative) net benefits, and evaluates whether that level of benefit (or cost) is likely.53

\footnotetext{
45 Exec. Order No. 12,866 § 3(b), 58 Fed. Reg. 51735 (Oct. 4, 1993) (exempting agencies listed in 44 U.S.C. $\S 3502$ ); 44 U.S.C. $§ 3502$ (listing agencies that meet the definition of "independent regulatory agency").

${ }_{46}$ Exec. Order No. 12,866 supra note 45, at $\S 1(b)(6)$.

${ }_{47} I d$.

48 See CIRCUlar A-4, supra note 2.

49 Id. at 10 .

$50 I d$. at 27.

${ }_{51} I d$.

${ }_{52} I d$. at 2.

${ }_{53} I d$. While CIRCUlAR A-4 mentions break-even analysis only briefly, Cass Sunstein, who served as the Administrator of OIRA during the Obama Administration, has described how agencies can perform high-quality break-even analysis. See Sunstein supra note 40. Richard Revesz compellingly argues that break-even analysis is a useful methodology but is not a panacea and agencies should invest in new quantification method, see Richard L. Revesz, Quantifying Regulatory Benefits, 102 CALIF. L. REV. 1424 (2014).
} 
Circular A-4 also provides agencies with guidance on the scope of costs and benefits that should be included in a cost-benefit analysis. Circular $A-4$ directs agencies to consider "all the important benefits and costs." 54 This includes both the direct benefits and costs - that is, those costs and benefits that are the primary purpose and consequence of the rule-as well as important costs and benefits that are secondary or unrelated to the statutory purpose of the action (also called "ancillary," "indirect," or "co-" benefits and costs).55

While Executive Order 12,866 and Circular A-4 apply to agency regulations, federal agencies such as the Department of Transportation, the Army Corps of Engineers, and the Department of Interior Bureau of Ocean Energy Management use many of the same approaches contained in these documents to inform their evaluation and decision making regarding the approval of infrastructure projects and other non-regulatory actions.56 Cost-benefit analyses of infrastructure projects are often prepared in concert with a project's environmental impact statement ("EIS") and regulations issued by the White House Council on Environmental Quality regarding implementation of the National Environmental Policy Act ("NEPA") which direct agencies to incorporate any cost-benefit analysis conducted to evaluate a project into its EIS.57

\footnotetext{
${ }_{54}$ CIRCUlaR A-4, supra note 2, at 15.

${ }_{55} I d$. at 26.

56 U.S. DEP'T OF TRANSP., OPERATIONS BENEFit/Cost ANALYSIS DESK REFERENCE (2012), https://ops.fhwa.dot.gov/publications/fhwahop12028/fhwahop12028.pdf [https:// perma.cc/9X4L-7B8B] (providing guidance on use of cost-benefit analysis in evaluating transportation infrastructure projects); NAT'L RESEARCH COUNCIL, ANALYTICAL Methods And Approaches for Water Resources Project Planning 48-72 (2004) (describing Army Corps of Engineers use of cost-benefit analysis in project development and evaluation); U.S. DEP'T OF THE INTERIOR, BUREAU OF OCEAN ENERGY MGMT., ECONOMic ANAlysis METhodology For the 2017-2022 OUTER Continental ShelF OIL AND GAS LEASING PROGRAM (2016), https://www.boem.gov/sites/default/files/oil-andgas-energy-program/Leasing/Five-Year-Program/2017-2022/Economic-Analysis-

Methodology.pdf [https://perma.cc/NYS6-XDPQ] (describing cost-benefit analysis methodology used by Department of Interior for evaluating offshore oil and gas lease sale program).

${ }_{57} 40$ C.F.R. $§ 1502.23(2020)$.
} 


\section{B. FERC Should Shift Course and Embrace Cost-Benefit Analysis}

As an independent agency, FERC is not required by existing executive order to develop a cost-benefit analysis when issuing regulations.58 And FERC has generally not elected to do so on its own accord.59 Nor is FERC clearly required by any executive order or statute to use cost-benefit analysis in non-regulatory decision making such as issuance of orders or certificates. And, as with regulations, FERC has not elected to do so, except in very limited circumstances. FERC considerations of RTO market rule changes are exercises of its ratemaking authority.60 As Part III explores in detail, FERC does not generally conduct or require a cost-benefit analysis for these types of actions. 61 Further, as explored in Part IV, FERC does not engage in a systematic accounting or transparent balancing of costs or benefits when evaluating natural gas infrastructure and, in fact, has recently explicitly disclaimed the use of monetized costbenefit analysis. 62 Nor does FERC require a cost-benefit

58 Exec. Order No. 12,866 supra note 45, at $\S 3(\mathrm{~b})$ (exempting agencies listed in 44 U.S.C. $\S 3502$ (2018)); 44 U.S.C. § 3502 (2018) (including Federal Energy Regulatory Commission in definition of "independent regulatory agency").

59 Agencies, including independent agencies, are required to submit rules to the Government Accountability Office ("GAO"), which maintains a database of those rules. Database of Rules, U.S. GOV'T ACCOUNTABILITY OFF., https://www.gao.gov/legal/otherlegal-work/congressional-review-act [https://perma.cc/J5W7-BVX9] (last visited Mar. 3, 2020). According to the GAO's database, since 1996, FERC estimated costs or benefits other than paperwork reporting obligations in only one rule. See, e.g., U.S. Gov'T Accountability OfF., OGC-00-17, Department of EnERgy, FEDERAL EnERgy REgulatory COMMission: Regional Transmission ORganization (2000), https://www.gao.gov/products/OGC-00-17. In part, this reflects the fact that FERC, with consultation from OIRA, determined that only nine regulations were "major" rules. See Database Search of FERC Major Rules, Congressional Review Act, U.S. Gov'T ACCOUNTABILITY OFF., https://bit.ly/30bgL03 [https://perma.cc/6ZAK-4APB] (last visited Aug. 10, 2019). See e.g., also, Data Collection for Analytics and Surveillance and MarketBased Rate Purposes, 168 FERC ๆ 61,039, at P 7 (July 18, 2019) (Glick, Comm'r, dissenting in part) ("[T] he Commission makes only a conclusory statement based on an unspecified burden to industry. It makes no effort to explain why that burden outweighs the benefits that Connected Entities Information would provide to the Commission's ability to carry out its enforcement responsibilities.").

60 Order No. 2000, supra note 13, at 31,043-044 (explaining that FERC approves of and sets RTO market rules through its ratemaking authority under FPA sections 205 and 206).

${ }_{61}$ See infra Part III.

62 See infra Part IV; see also Florida Southeast Connection, LLC, 162 FERC 9 61,233, at PP 39-44 (Mar. 14, 2018) [hereafter SMP Project Remand Order] (explaining that FERC 
analysis in support of its issuance of mandatory reliability standards for the bulk power system.63 And FERC rejected requests that it use cost-benefit analysis to justify its approval of economic incentives intended to facilitate the development of certain transmission infrastructure.64

Yet despite what appears to be a general indifference, and even sometimes hostility, to cost-benefit analysis, FERC has not wholly rejected the importance of evaluating and comparing the costs and benefits of its actions. As discussed in Part III, FERC used cost-benefit analysis to inform its regulatory actions during the last electric system transformation.65 And during the last natural gas infrastructure buildout, FERC framed its inquiry into whether to approve natural gas pipelines as a balancing of costs and benefits. 66 In two areas, FERC has consistently required and applied a systematic and quantitative evaluation of cost and benefits. FERC has interpreted its authority to issue licenses for hydroelectric projects to include a requirement that it consider certain limited quantified costs and benefits .67 And, due to unfavorable court decisions, FERC now requires a costbenefit analysis to justify the allocation of transmission

"do[es] not monetize benefits or monetize adverse economic effects" of proposed pipeline projects).

63 North American Electric Reliability Corp., 117 FERC \ 61,126, at P 97 (Oct. 30, 2006) ("EPAct 2005 does not mandate a case-by-case cost-benefit analysis and we are not prepared to mandate that the Reliability Standard development process include an analysis of what the cost and benefit implications might be").

${ }_{64}$ Promoting Transmission Investment Through Pricing Reform, 116 FERC 91 ,057, at P 65 (July 20, 2006) ("We reaffirm the NOPR's determination not to require applicants for incentive-based rate treatments to provide cost-benefit analyses.").

65 See infra Part III(A)(3).

661999 Policy Statement, supra note 16, at 61,737.

67 See Mead Corporation, 72 FERC $\uparrow$ 61,027, 61,068-69 (July 13, 1995) (describing FERC interpretation of FPA section 10(a)(1) obligation to consider all aspects of the public interest when evaluating hydropower licenses to include an economic analysis requirement). See also U.S. Fish AND WILDLIFE SERVICE, ECONOMIC ANALYSIS FOR Hydropower Project Relicensing: Guidance and Alternative Methods at $3-1$ to 3-21 (1998), https://www.fws.gov/policy/hydroindex.htm [https://perma.cc/2JAC-LET5] [hereinafter U.S FISH AND WILDLIFE SERVICE] (describing FERC monetization of certain costs and benefits under its traditional hydroelectric licensing process); KURT StePHENSON \& LEONARD SHABMAN, REsOURCES FOR THE FUTURE, ECOSYSTEM VALUATION AND HYDROPOWER LICENSING DECISIONS: LESSONS FROM FERC EXPERIENCE 16-20 (2018), http://www.rff.org/files/document/file/RFF-WP\%20Shabman

-final.pdf [https://perma.cc/876A-GPTL] (describing monetization of environmental mitigation costs and electric power costs and benefits in Alternative Licensing Process and Integrated Licensing Process proceedings). 
development costs to specific beneficiaries.68 As a result, FERC developed some practices and institutional capacity to conduct and evaluate cost-benefit analyses both in the context of electric ratemaking and infrastructure approvals.

FERC should build upon its practice during the last energysystem transition and the limited areas of continued application to embrace cost-benefit analysis as a more widely applied method of evaluating its actions and as a decision-making criterion when choosing among actions. To that end, it is useful to specify what "using" cost-benefit analysis would, and would not, mean.

Consistent with the conception of cost-benefit analysis in Executive Order 12,866 and Circular A-4, FERC should follow these five criteria:

1. FERC would identify, quantify, and monetize the expected costs and benefits of a particular action to the greatest degree feasible. Where possible, FERC would quantify and monetize those costs and benefits using available scientific, economic, and modeling tools. Where quantification is not possible, costs and benefits would be qualitatively described.

2. FERC would look at as broad a scope of costs and benefits as is permissible under its particular statutory frameworks. As a regulator entrusted with advancing the public interest, 69 FERC should look at the broad swath of consequences of its actions, including ancillary costs and benefits, rather than narrowly consider only the consequences that implicate the core purposes of the particular statutory scheme, unless Congress has explicitly limited FERC's authority to do so. As explained in Parts III and IV, the FPA and NGA provide flexible enough statutory frameworks to support consideration of relevant ancillary benefits and costs, including the environmental and resilience consequences of FERC's decision making.70

${ }_{68}$ See Gabe Maser, It's Electric, But FERC's Cost-Causation Boogie-Woogie Fails to Justify Socialized Costs for Renewable Transmission, 100 GEO. L.J. 1829, 1836-37 (2012) (identifying court decisions that require FERC to allocate transmission costs to beneficiaries using an individualized cost-benefit analysis).

6915 U.S.C. $\$ 717$ (a) (2018) ("Federal regulation in matters relating to the transportation of natural gas and the sale thereof in interstate and foreign commerce is necessary in the public interest"); 16 U.S.C. § 824(a) (2018) ("Federal regulation of matters relating to ... the transmission of electric energy in interstate commerce and the sale of such energy at wholesale in interstate commerce is necessary in the public interest").

70 See infra Part III(B), IV(B). 
3. FERC would use the results of the quantitative and qualitative analysis to inform its decisions. In general, action would be taken only when the Commission determines, based on the analysis conducted, that the expected benefits are likely to exceed expected costs.

On the other hand, there are also important limits on what "using" cost-benefit analysis should mean.

4. FERC would not apply cost-benefit analysis to all of its decisions. FERC annually issues well over one thousand orders.71 Many of these are ministerial orders that have been delegated to staff, and do not require a vote of the Commission.72 Others involve approving individual wholesale transactions and small gas pipeline upgrades or abandonments. Adopting a costbenefit analysis requirement for these actions would be impractical. But, the volume of FERC's work is not a reason to forgo using cost-benefit analysis in those cases for which it would be helpful. To that end, FERC can adopt the same long-standing monetary threshold for cost-benefit analysis that is specified in Executive Order 12,866: only those orders that are expected to have an annual economic impact of $\$ 100$ million or more would carry a cost-benefit requirement.73 Such a threshold would likely limit cost-benefit analysis requirements to industry-wide rulemakings, 74 major changes in individual wholesale organized electric markets, 75 large pipeline projects, 76 and other actions of similar scale.

71 See Norman C. Bay Letter, supra note 37.

72 See FERC General Rules on Delegations, 18 C.F.R. § 375.301 (delegating authority to staff to act in uncontested proceedings without a vote of the Commission).

73 Exec. Order No. 12,866 §§ 3(f)(1), 6(a)(3)(C), 58 Fed. Reg. 51,735 (Sept. 30, 1993).

74 See, e.g., Robbie OrVis ET AL., EnERgy InNovation Policy \& Tech., The Department of Energy's Grid Resilience Pricing Proposal: A Cost Analysis 7 (2017), https://energyinnovation.org/resources/our-publications/ [https://perma.cc/ YM28-4YKQ] (finding proposed rule would increase costs by at least $\$ 311$ million annually).

75 See, e.g., Protest of the Independent Market Monitor for PJM at attach. B, 7, PJM Interconnection, LLC, Docket No. EL19-58 (May 15, 2019) (estimating proposed market rule change to the mechanism for procuring operating reserves would increase energy revenues $\$ 369.4$ million per year and reserve revenues $\$ 130.8$ million per year).

76 See ICF Int'L, The Economic Impacts of the Atlantic CoAst Pipeline 5 (2015), https://www.abralliance.org/wp-content/uploads/2015/09/Economic_Impacts-

ACP_ICFI_study_for_Dominion_2-9-15.pdf [https://perma.cc/ZNQ3-BMXY] (finding pipeline will result in expected annual net energy savings of $\$ 377$ million between 2019 and 2038). 
5. Using cost-benefit analysis would not result in a requirement that FERC subject its orders to interagency review. Executive Order 12,866 requires agencies to submit their proposed and final rules to the Office of Management and Budget's Office of Information and Regulatory Affairs ("OIRA”), which manages a process of White House and interagency review. 77 Commentators are split on whether such review would be appropriate or desirable for independent agencies. 78 This Article takes no position on the question, nor does it need to. A voluntary decision by FERC to adopt cost-benefit analysis would not also require it to subject its rules to OIRA review.

\section{The Case for Cost-Benefit Analysis at FERC}

Cost-benefit analysis will allow FERC to balance competing interests, explain its choices clearly to the public and its congressional overseers, and, ultimately, act in ways that make the American people better off. Particularly given the growing demand from the courts and the executive branch that agencies fully consider the costs and benefits of their actions, now is the time for FERC to embrace cost-benefit analysis. This section develops a number of these reasons for adopting cost-benefit analysis.

\section{Improving Social Welfare}

Cost-benefit analysis provides a formal accounting that enables agencies such as FERC to act in ways that improve overall wellbeing-or social welfare. 79 Government action improves social welfare when its benefits exceed its costs-that is, when the action produces net benefits. When choosing among a set of alternatives, the social welfare maximizing option is the alternative with the greatest net benefits.

The formalized process of cost-benefit analysis allows decision makers to more confidently and clearly evaluate those net

77 Exec. Order No. 12,866 § 6, 58 Fed. Reg. 51,735 (Sept. 30, 1993).

78 See Revesz, supra note 8, at 588-89 (advocating for regulatory review of independent agency actions); Emily Hammond, Keeping the Independent Agencies Independent, CPRBLOG (Sept. 13, 2012), http://www.progressivereform.org/CPRBlog.cfm? idBlog=BFDB1B7B-CA35-04BF-2ABAD93CE4D33D89 [https://perma.cc/LUU6-Z85Z]. 79 See Matthew D. Adler \& Eric A. Posner, Rethinking Cost-Benefit Analysis, 109 YAlE L.J. 165, 196 (1999). 
benefits than they would be able to do with an intuitive balancing. It does so by "focus[ing] attention directly on the human consequences" of government actions, 80 and by explicitly identifying the tradeoffs inherent in choosing a particular alternative. By placing the costs and benefits of an action into equivalent metrics, such as dollars, Commissioners can undertake a more rigorous evaluation of the tradeoffs. 81

For example, in a series of recent orders, FERC directed RTOs to make changes to their capacity markets-markets intended to ensure there is sufficient generation available to meet future peak load-in order to counteract the effects of state programs that support clean energy resources and address climate change.82 FERC has justified the need for these changes by appealing to abstract principles such as "investor confidence" or "market integrity." But in doing so, FERC made no attempt to quantitatively measure the likely costs of these actions or the tradeoffs presented.83 As a result, individual Commissioners were left to subjectively determine whether these changes would truly improve the markets. Cost-benefit analysis could have played a disciplining role by testing each Commissioner's intuition.

This is not to say that FERC should look only at costs and benefits that can be monetized. Some consequences of an action affect welfare but may not be easily monetizable.84 In such cases, FERC should evaluate non-monetizable costs and benefits qualitatively and consider use of tools such as break-even analysis.

Another key feature of cost-benefit analysis that facilitates maximizing social welfare is that it demands the inclusion of a broad scope of costs and benefits, including ancillary costs and benefits. As Professor Cass Sunstein has put it, "by broadening the viewscreen, cost-benefit analysis helps to overcome some of

${ }_{80}$ Cass R. Sunstein, Cost Benefit Analysis and Arbitrariness Review, 41 HARV. EnVTL. L. REV. 1, 9 (2017).

81 Eric Posner \& E. Glen Weyl, Benefit-Cost Paradigms in Financial Regulation, 43 J. LEGAL STUD. S1, S10 (2014).

82 See Calpine Corp. v. PJM Interconnection LLC, 169 FERC ๆ 61,239 (Dec. 19, 2019); ISO New England Inc., 162 FERC \ 61,205 (Mar. 9, 2018).

83 See Calpine Corp., 169 FERC \ 61,239, at P 57(Glick, comm’r, dissenting).

${ }_{84}$ Sunstein, supra note 80 , at 9-10. 
the unfortunate effects of selective attention." 85 For example, climate change and public health costs are a significant consequence of energy transportation and use. Even if limiting these consequences is not the core purpose of FERC's actions under the FPA and NGA, these ancillary consequences can significantly influence the extent to which a project or market rule will improve social welfare. Yet, FERC generally does not quantify those co-benefits and co-costs in the context of electric market rules and natural gas pipeline approvals. In effect, FERC treats both those costs and benefits as worthless.86 As a result, FERC may regularly fail to take actions that maximize social welfare. Cost-benefit analysis can help prevent that failure-particularly when a specific component of that analysis is consideration of ancillary costs and benefits. 87

Again, the recent capacity market orders provide a useful example. In one such order, FERC determined that state policies were undermining "the integrity of competition in the wholesale capacity market against unreasonable price distortions and cost shifts" and so required correction.88 But FERC's conclusion was the result of its failure to consider the efficiency improvements that at least some state policies made by reducing climate damages imposed by fossil generators. 89 Had FERC used cost-benefit analysis to evaluate the market rule changes it was proposing-including consideration of the climate consequences of the market design-FERC would have had to more clearly confront the error in its reasoning and could have mandated changes that corrected for distortionary state

$85 I d$. at 10.

86 See Gulf LNG Liquefaction Co., 168 FERC \ 61,020, at P 9 (July 16, 2009) (Glick, Comm'r, dissenting) [hereinafter Gulf LNG].

87 See Samuel J. Rascoff \& Richard L. Revesz, The Biases of Risk Tradeoff Analysis: Towards Parity in Environmental and Health-and-Safety Regulation, 69 U. CHI. L. REV. 1763, 1823-34 (2002).

88 Calpine Corp. v. PJM Interconnection LLC, 163 FERC $\uparrow$ 61,236, at P 150 (June 29, 2018).

89 See Sylwia Bialek \& Burcin Unel, Capacity Markets and Externalities (2018), http://policyintegrity.org/files/publications/Capacity_Markets_and_Externalities_Repor t.pdf [https://perma.cc/HWG7-V6X7]. 
policies without targeting policies that improve market efficiency and social welfare.90

Of course, when taking a particular action, FERC will be limited to considering only those factors Congress permits it to consider under a particular statutory scheme.91 If certain consequences cannot be considered, those consequences would not usefully be included in a cost-benefit analysis, even if those effects would have some influence on social welfare. However, courts have been skeptical of attempts to read general statutory phrases as implying Congressional intent to have agencies ignore the costs or benefits of their actions.92 This includes consideration of co-benefits.93 As explained in Parts III and IV, both the FPA and NGA can be reasonably interpreted to include a broad range of costs and benefits, including, in many instances, the costs to the public that have not been internalized by market participants such as the climate change costs of greenhouse gas emissions.

\section{Transparency and Accountability}

Cost-benefit analysis can also enhance the transparency of FERC's decision making by more clearly establishing the stakes of a particular action and the good and bad consequences of that action. Individually identifying and quantifying costs and benefits can clarify the trade-offs among different interests and alternatives.

Transparency is particularly important for the types of highly technical yet consequential decisions often at stake in FERC

\footnotetext{
90 See Reply Comments of the Institute for Policy Integrity at New York University School of Law at 22-24, Calpine Corp. v. PJM Interconnection LLC, Docket No. EL1649-000 (Nov. 6, 2018), https://policyintegrity.org/documents/Policy_Integrity_

Reply_Docket_EL18-178_FOR_FILING.pdf [https://perma.cc/7HQ8-Q5QE].

91 State Farm Mut. Auto. Ins., 463 U.S. at 42-43. See also NAACP v. Fed. Power Comm'n, 425 U.S. 662 (1976).

92 Michigan v. EPA, 135 S.Ct. 2699, 2707 (2015).

93 Michael A. Livermore \& Richard L. Revesz, Rethinking Health-Based Environmental Standards, 89 N.Y.U. L. REV. 1184, 1250 (2014) (describing D.C. Circuit consideration in Am. Trucking Ass'n v. EPA, 175 F.3d 1027, 1051-52 (D.C. Cir. 1999)); Ctr. for Biological Diversity v. Nat'l Highway Traffic Safety Admin., 538 F.3d 1172, 1193-1203 (9th Cir. 2008) (reversing agency decision for consideration of ancillary costs but not ancillary benefits).
} 
proceedings. 94 Well-funded stakeholders, such as public utilities, can afford to conduct their own analysis of potential FERC action that directly affect their interests. Public interest organizations are often unable to do the same.95 Without an independent and publicly available analysis, self-interested stakeholders can use their own analyses to influence the Commission at the expense of the public.96 And industry analyses may leave out important categories of costs and benefits, such as the environmental consequences of a market rule change, which are often not in their interests to include.97 Analyses by the Commission's expert staff can reduce reliance on analyses produced by self-interested and well-funded stakeholders and provide Commissioners with a neutral, independent, look at the consequences of the actions under consideration. Moreover, by alerting the public to costs and benefits that affect different constituencies and interests, costbenefit analysis can help resource-constrained stakeholders prioritize engagement and identify flaws in the assumptions underlying the analysis.98 This is particularly valuable in the context of proceedings before FERC and in stakeholder processes before RTOs that address complex but consequential electric market rules, where members of the public rarely participate. 99 This disadvantages stakeholders who are not direct market participants and therefore do not have the financial resources or tools available to fully model and

94 Richard L. Revesz \& Michael A. Livermore, Retaking Rationality: How CostBenefit Analysis Can BetTer Protect the Environment AND OuR Health 13 (2008) ("[B]ecause of the technical nature of many regulatory decisions, bureaucrats and experts deep in the bowels of the federal government wield substantial power over our lives. Cost-benefit analysis can be used to ensure that their decisions are based on reasoned analysis").

95 Christina Simeone, Kleinman Ctr. For Energy Policy, PJM Governance: Can REFORMS IMPROVE OUTCOMES 39 (2017), https://kleinmanenergy.upenn.edu/sites/ default/files/proceedingsreports/PJM\%20Governance\%20Reforms.pdf [https://perma.cc/MB26-BJVP] (discussing resource burden on participation in RTO stakeholder processes, including analytical requirements, particularly for small entities).

96 Sunstein, supra note *, at 27-28.

97 Ari Peskoe \& Kate Konschnik, Climate implications of FERC Proceedings 10 (2017), http://eelp.law.harvard.edu/wp-content/uploads/Climate-and-FERC-Proceedings .pdf [https://perma.cc/46AA-2BER].

98 Adler \& Posner, supra note 79 at 175.

99 See Peskoe \& KonsChniK, supra note 97. 
understand the implications of a given rule change. 100 Stakeholders-such as environmental NGOs, consumer advocates, and states-face substantial participation barriers in the RTO process and before FERC.101 Cost-benefit analysis can make the consequences of proposed market rule changes more transparent to these stakeholders which can facilitate more informed participation.102

Transparency and enhanced engagement can in turn, improve the democratic legitimacy and accountability of FERC decisions. 103 As Professors Richard Revesz and Michael Livermore have written, "[b]y providing a more accurate assessment of the real costs and benefits of a decision, formalized cost-benefit analysis reveals the distortions of politics-the back-room deals and special-interest politics-for what they are."104 Similarly, Cass Sunstein has explained, "by promoting a focus on actual consequences" cost-benefit analysis can "quiet the noise generated by influential interest groups." 105 The need for accountability is particularly acute in the case of RTO-proposed market rule changes. While nominally independent, RTO's are generally governed by a stakeholder process that, in practice, allows private interests to exert substantial influence on the RTO's actions. 106 Moreover, FERC has historically taken a deferential approach to evaluating RTO filings.107 As a result, RTOs act as policymakers that are not

100 See Michael H. Dworkin \& Rachel Aslin Goldwasser, Ensuring Consideration of the Public Interest in the Governance and Accountability of Regional Transmission Organizations, 28 ENERGY L.J. 543, 584 (2007).

$101 \mathrm{Id}$.

102 Travis Kavulla, Problems in Electricity Market Governance: An Assessment, R Street Policy Study No. 180 at 11-12 (Aug. 2019), https://www.rstreet.org/wpcontent/uploads/2019/08/FINAL-RSTREET180.pdf [https://perma.cc/L92T-4S47].

${ }_{103}$ Paul Rose \& Christopher J. Walker, Dodd-Frank Regulators, Cost-Benefit Analysis, and Agency Capture, 66 STAN. L. REv. OnLine 9, 13 (2013) ("Cost-benefit analysis helps alleviate... concerns [about legitimacy and democratic accountability] by making agency decisionmaking more transparent to the public and to elected officials who can exercise control over the agencies").

104 REVESZ \& LIVERMORE, supra note 94, at 12.

105 Sunstein, supra note 80, at 10

106 See Dworkin \& Aslin Goldwasser, supra note 100, at 582-83. SimEONE, supra note 95, at 37-39 ("[A] wide range of interests note the theoretical potential for incumbent interests to dominate RTO/ISO stakeholder processes, to the detriment of competition and efficient outcomes.”).

107 KAVULLA, supra note 102, at 4. This was recently exacerbated by a D.C. Circuit decision that restricts FERC to approving or denying RTO-proposed market rule changes 
subject to the same level of oversight and accountability to act in the public interest as regulatory agencies.108 By requiring RTO market rule changes to be justified with a cost-benefit analysis, FERC can more effectively ensure that RTOs fulfill their purpose of promoting economic efficiency.109

For FERC, the potential for influence comes not only from incumbent market actors, but also from the Department of Energy ("DOE"). FERC is an agency that Congress has imbued with significant independence from the executive branch, even as compared to other independent regulatory commissions. 110 Yet, DOE possesses unique authority to put issues onto FERC's agenda. Under Section 403 of the Department of Energy Organization Act, DOE can issue proposed rules that would govern subjects under the authority of FERC, and FERC is then required to either finalize or reject.111 In doing so, DOE can attempt to exert political influence on the Commission. It is entirely proper for an executive branch agency-accountable to the democratically-elected President-to put specific proposals on FERC's agenda in line with authority granted by Congress to do just that.112 But adopting a policy that both proposed and final rules require a cost-benefit analysis can help ensure that any DOE proposals are rational, well thought-out, and supported by the record.

A recent DOE Notice of Proposed Rulemaking ("NOPR") provides a useful example. In 2017, DOE issued a NOPR that, if adopted, would have required electricity market changes intended to ensure the profitability of coal and nuclear plants that met certain criteria.113 The NOPR was allegedly intended to preserve electricity generators that provided uncompensated

and prohibits FERC from imposing changes or conditions. NRG Power Mktg. LLC v. FERC, 862 F.3d 108, 115 (D.C. Cir. 2017).

108 KAVULLA, supra note 102, at 12-13.

109 Id. at 14 .

110 Kirti Datla \& Richard L. Revesz, Deconstructing Independent Agencies (and Executive Agencies), 98 CORNELL L. REV. 769, 825 (2013) (finding FERC has at least as many indicia of independence as any other agency).

11142 U.S.C. $\S 7173$ (2018).

112 Datla \& Revesz, supra note 110, at 842 (disputing the binary view of agency independence and arguing for the legitimacy of presidential control over agencies within the bounds set by Congress).

113 Grid Resiliency Price Rule, 82 Fed. Reg. at 46,942 (proposed Oct. 10, 2017). 
"resilience" benefits to the grid.114 However, there is substantial evidence that the proposal was, in fact, the result of political commitments made by President Trump after lobbying by key donors.115 In its NOPR, DOE did not attempt to demonstrate that the costs of its proposed program would exceed the benefits; indeed then-DOE Secretary Rick Perry argued that the bailout was worth any cost.116 Ultimately, FERC dispensed with the NOPR, largely due to DOE's failure to meet even the basic requirements for a FERC regulation under the FPA. 117 However, this example highlights a risk that FERC's reputation for fact-based decision making could be undermined by a more diligent DOE.118 A policy that rulemakings must include a costbenefit analysis could help reduce the extent to which FERC adoption of a regulation after a future DOE NOPR is seen as an unjustified political act that undermines the independence and credibility of the Commission.

Moreover, FERC's failure to use cost-benefit analysis leads it to leave important categories of costs and benefits entirely absent from its articulated decision making, even when those factors may be driving an outcome. One of the most important consequences of FERC's actions is their effect on climate change.119 However, discussion of the climate consequences of its actions are largely absent from FERC orders explaining its decision making. This is true even for actions where Commissioners have identified climate change as a priority that informed their decisions.120 As a result, it appears that FERC is

${ }_{114} I d$.

115 David Roberts, A Moment of Truth Arrives for Rick Perry's Widely Hated Coal Bailout, Vox (Dec. 11, 2017), https://www.vox.com/energy-and-environment/2017/12/9/ 16745084/rick-perry-coal-bailout-ferc [https://perma.cc/S4DM-W3LN].

116 Richard Valdmanis, Nuclear, Coal Bailout Worth Any Cost 'To Keep America Free': U.S. Energy Chief, REUTERS (June 28, 2018), https://www.reuters.com/article/us-gasconference-perry-grid/nuclear-coal-bailout-worth-any-cost-to-keep-america-free-u-senergy-chief-idUSKBN1JO2JS [https://perma.cc/35EL-3GWN].

117 Grid Reliability and Resilience Pricing Grid Resilience in Regional Transmission Organizations and Independent System Operators, 162 FERC \ 61,012 (Jan. 8, 2018) [hereinafter Resilience Order].

118 Iulia Gheorghiu, LaFleur Cautions on Administrative Interference as She Exits FERC, UTIL. DIVE (July 29, 2019), https://www.utilitydive.com/news/lafleur-cautions-onadministrative-interference-as-she-exits-ferc/559551/ [https://perma.cc/3ZM5-LN64]. 119 See Glick \& Christiansen, supra note 19.

${ }_{120}$ Christopher J. Bateman \& James T.B. Tripp, Toward Greener FERC Regulation of the Power Industry, 38 HARV. EnvTL. L. REV. 275, 278 (2014); Compare Rod Kuckro, 
making decisions without fully disclosing its reasoning, limiting transparency and accountability.

\section{Anticipating Executive Branch Mandates}

The executive branch may be in the process of deepening the reach of the cost-benefit state.121 By proactively adopting costbenefit analysis on its own terms now, FERC can build processes and expertise in ways that would allow the Commission to better defend its decision making before OIRA.

There is long-standing consensus in the executive branch that the President has legal authority to apply regulatory review executive orders to independent commissions. 122 Some Presidents have decided that picking a political fight to do so may not be worth the benefit.123 That may be changing.

While President Obama continued to exclude independent agencies from the requirements of regulatory review when he reaffirmed Executive Order 12,866,124 just months later he issued Executive Order 13,579. 125 Titled Regulation and Independent Regulatory Agencies, it explained that agency decisions "should be made only after consideration of their costs and benefits (both quantitative and qualitative)" and encouraged independent regulatory agencies to adopt the kind of regulatory approach that executive branch agencies have been subject to since 1981.126

McNamee, Glick Clash Over Climate, ENERGYWIRE (July 19, 2019), https://www.eenews.net/energywire/2019/07/19/stories/1060757919

[https://perma.cc/ADG3-7HPT] (quoting FERC Chairman Neil Chatterjee as saying Order 841 was justified, in part, on climate grounds) with Electric Storage Participation in Markets Operated by Regional Transmission Organizations and Independent System Operators, Order No. 841, 162 FERC $\ 61,127$ (Feb. 15, 2018) (no discussion of climate change).

121 But see Daniel A. Farber, Regulatory Review in Anti-Regulatory Times, 94 CHI.-KeNT L. REV. 383 (2019) (raising concerns that the Trump administration is abandoning the use of balanced and fact-based cost-benefit analysis in order to further its deregulatory agenda).

122 Datla \& Revesz, supra note 110, at $838 \mathrm{nn} .387$, 388, 390 (identifying long-standing executive branch legal opinions).

123 Id. at 837 \& n. 379 .

${ }_{124}$ Exec. Order. No. 13,563 § 7(a), 76 Fed. Reg. 3821 (Jan.18, 2011).

125 Exec. Order. No. 13,579, 76 Fed. Reg. 41,587 (July 11, 2011).

${ }_{126} I d$. at $\S 1$ (a), (c) (stating that independent regulatory agencies "should comply" with the provisions of Executive Order 13,563, which reaffirmed and extended President Clinton's Executive Order 12,866). 
Pressure since then has only continued to build. In 2013, the Administrative Conference of the United States recommended that all independent regulatory agencies adopt a series of practices that would encourage and enable the use of cost-benefit analysis for rulemaking.127 In 2015, a distinguished group of legal scholars submitted a letter in support of applying costbenefit analysis (and OIRA review more broadly) to independent agencies, and explained that there is a consensus that it is within the President's authority to do so by executive order.128 In 2016, former OIRA Administrators from the Reagan, Clinton, Bush, and Obama administrations embraced a series of recommendations to the incoming Trump administration regarding regulatory review, including application of the costbenefit analysis requirement to independent agencies. 129

Most recently, OMB has taken a half-step towards requiring cost-benefit analysis by independent agencies. The Congressional Review Act requires that "major" rules, including those from independent agencies, have a delayed effective date, 130 and gives OIRA final responsibility for determining which rules are major.131 In a 2019 memorandum, acting OMB director Russell Vought outlined a new process by which OIRA would exercise this responsibility.132 Specifically, OMB clarified

127 Admin. Conference of the U.S., Recommendation 2013-2, Benefit-Cost ANALYSIS AT INDEPENDENT REGULATORY AGENCIES (June 13, 2013).

128 Letter from Jonathan H. Adler et al. to Ronald H. Johnson, Chairman, S. Comm. on Homeland Sec. \& Gov. Aff. \& Thomas R. Carper, Ranking Member, S. Comm. on Homeland Sec. \& Gov. Aff. (June 17, 2015), https://web.archive.org/web/2018092417 2015/https:/www.portman.senate.gov/public/index.cfm/files/serve?File_id=221f0caebde3-4312-baa1-ccd754f6b10a.

129 InSt. FOR POLICY INTEGRITy, STRENGTHENING REgUlatory REview: RECOMMENDATIONS FOR THE TRUMP ADMINISTRATION FROM FORMER OIRA LEADERS 1012 (2016), https://policyintegrity.org/files/publications/RegulatoryReview_Nov2016.pdf [https://perma.cc/5DR7-78ZR].

1305 U.S.C. $\S 801(\mathrm{a})(3)(2018)$.

1315 U.S.C. $\S 804(2)(2018)$.

132 Memorandum from Russell T. Vought to Heads of Executive Departments and Agencies re: Guidance on Compliance with the Congressional Review Act (April 11, 2019), https://www.whitehouse.gov/wp-content/uploads/2019/04/M-19-14.pdf [https://

perma.cc/GJ6H-9SSM] [hereinafter Russell T. Vought Memo]. Note that this requirement applies to all "rules" as that term is defined by the Congressional Review Act ("CRA") and interpreted by the Government Accountability Office. Id. at 1. This definition is more expansive than the type of regulations subject to Executive Order 12,866. Id. at 3. While there is some ambiguity, this definition may not include FERC orders related to individual RTO market rule filings or infrastructure permitting requests. See 5 U.S.C. § 804(3)(A) (2018) (excluding rules of particular applicability 
that it will require agencies, including independent agencies, to quantify costs and benefits of rules, using methods outlined in Circular A-4, before it will sign off on a rule's designation as major.133 Moreover, OMB in effect claimed the authority to prohibit independent agencies from promulgating rules without sufficient analysis.134

This history suggests that additional requirements may be imposed on FERC by the executive branch over time. Even now, OMB's memorandum creates some risk that OIRA will delay promulgation of FERC rules until FERC can demonstrate to OIRA's satisfaction whether a rule should be classified as "major." Adopting cost-benefit analysis now will allow FERC to further develop the institutional and methodological expertise needed to satisfy the demands of executive branch review. By speaking OIRA's language, FERC will be better prepared to avoid delays and defend against attempts to interfere with its decision making. 135

\section{Limiting Legal Risk}

Proactively working to incorporate cost-benefit analysis into FERC's decision making process can also limit the risk that FERC's decisions will fail judicial review. The past thirty-five years have seen a gradual advancement of the cost-benefit state, not only at the executive level, but also in the courts.136 Over that time the courts' views of cost-benefit analysis has shifted towards the positive.137 In particular, a series of decisions over the past ten years at the United States Supreme Court and the United States Court of Appeals for the District of Columbia Circuit may signal the increasing importance of agency

including actions that approve future rates, or prices). However, it would likely cover any industry-wide regulations and guidance documents or FERC action applicable to all RTOs.

133 Russel T. Vought Memo, supra note 132, at 5.

${ }_{134} I d$. ("insufficient or inadequate analysis may delay OIRA's determination and an agency's ability to publish a rule and to make the rule effective").

135 See Michael A. Livermore, Cost-Benefit Analysis and Agency Independence, 81 U. CHI. L. REV. 609, 622-25 (2014) (arguing that use of cost-benefit analysis can insulate agencies from political interference by regularizing the mechanism of OIRA review). 136 See generally Cass R. Sunstein, The Cost-Benefit Revolution (2018).

${ }_{137}$ See Cecot \& Viscusi, supra note 4, at 581-85. 
consideration of costs and benefits in order to survive judicial review.138

In 2009, in Entergy Corp. v. Riverkeeper, the Supreme Court found that EPA's use of cost-benefit analysis as the basis for its rule to establish cooling water intake limits for power plants was permissible. 139 More recently, the Supreme Court went beyond allowing an agency to use cost-benefit analysis as a decision making framework and rejected as unreasonable a statutory interpretation that costs need not be taken into account in a particular regulatory action. In Michigan v. EPA, the Supreme Court considered an Environmental Protection Agency ("EPA") decision that regulation of mercury from power plants was "appropriate and necessary" based only on public health concerns and not the economic costs to industry. 140 Justice Scalia, writing for the Court, reasoned that while the "capaciousness of th[e] phrase" appropriate and necessary "leaves agencies with flexibility, an agency may not entirely fail to consider an important aspect of the problem when declaring whether regulation is appropriate." 141 The Court concluded that it is not "rational, never mind 'appropriate" to ignore costs or benefits 142 and that "no regulation is 'appropriate' if it does significantly more harm than good." 143 Justice Kagan's dissent suggests the embrace of an agency's obligation to consider costs and benefits is widely held.144

138 See Sunstein, supra note 80, at 14-19.

139 Entergy Corp. v. Riverkeeper, Inc., 556 U.S. 208, 226 (2009).

140 Michigan v. EPA, 135 S. Ct. 2699, 2705 (2015).

141 Id. at 2707.

${ }_{142}$ While the issue in Michigan was whether EPA was required to consider costs, the majority opinion includes language suggesting a similar approach to benefits. Id. at 2702 ("Consideration of cost reflects the understanding that reasonable regulation ordinarily requires paying attention to the advantages and the disadvantages of agency decisions.”) (emphasis added).

${ }_{143} I d$.

${ }_{144} I d$. at 2716-17 (Kagan, J., dissenting) ("Unless Congress provides otherwise, an agency acts unreasonably in establishing 'a standard-setting process that ignore[s] economic considerations."'). Justice Kagan's dissent arrived at a different outcome from the majority based on the fact that EPA had considered costs when setting the level of standards. Id. at 2719-21. 
The Court did not go so far as to require agencies to act based on a formal cost-benefit analysis.145 But Professor Sunstein has called the Court's decision in Michigan a "rifle shot" announcing the arrival of the cost-benefit state.146 Agencies are on notice that, all else being equal, they must substantively "consider" the consequences of each action and be able to reasonably claim that they believe the benefits of an action are greater than the costs. While executive agencies subject to the regulatory review executive orders generally do so as a matter of course, those that do not-namely, independent regulatory agencies-are at some legal risk if they fail to weigh costs and benefits in a way that meets the Court's expectations. 147

The D.C. Circuit has gone even further in signaling that agency decisions may be at legal risk if they fail to sufficiently quantify costs and benefits. In Business Roundtable v. SEC, the D.C. Circuit invalidated a requirement that public companies provide shareholders information about and an opportunity to vote on shareholder-nominated board candidates. 148 In promulgating the rule, the Securities and Exchange Commission ("SEC") determined that the "potential benefits of improved board and company performance and shareholder value' [were] sufficient to "justify [its] potential costs." 149 Nonetheless, the court held that the SEC had acted arbitrarily by failing to adequately quantify and weigh costs and benefits. 150 This

$145 I d$. at 2711 ("We need not and do not hold that the law unambiguously required the Agency, when making this preliminary estimate, to conduct a formal cost-benefit analysis in which each advantage and disadvantage is assigned a monetary value.").

${ }_{146}$ Cass R. Sunstein, Thank, Justice Scalia, for the Cost-Benefit State, BloomberG VIEW (July 7, 2015), https://www.bloomberg.com/opinion/articles/2015-07-07/thanks-justicescalia-for-the-cost-benefit-state [https://perma.cc/5LXT-DJS7]. There remains disagreement about the extent to which the Supreme Court's opinion in Michigan signals a substantial change in favor of cost-benefit analysis. See Amy Sinden, A "Cost-Benefit State”: Reports of Its Birth Have Been Greatly Exaggerated, 46 ENVTL. L. REP. NEWS \& ANAlYsis 10,933 (2016); Andrew M. Grossman, Michigan v. EPA: A Mandate for Agencies to Consider Costs, 2015 CATO SUP. CT. REV. 281 (2015).

147 See Grossman, supra note 146, at 298-99 (discussing impact of Michigan on independent regulatory agencies).

148 Bus. Roundtable v. SEC, 647 F.3d 1144 (D.C. Cir. 2011).

149 Id. at 1148 .

150 Id. at 1148-49 ("the Commission inconsistently and opportunistically framed the costs and benefits of the rule; failed adequately to quantify the certain costs or to explain why those costs could not be quantified"). 
decision "create[s] a warning for any agency that fails to compare costs and benefits-at least if authorized to do so." 151

Of course, a Commission's exposure to legal risk may depend on the particular statutory provisions under which it acts. Even a general presumption in favor of cost-benefit analysis may be overcome by congressional directives that limit its application.152 But, as explained in Parts III and IV, FERC regularly acts under the authority of broadly-worded and capacious statutes-electric market rules must be "just and reasonable," 153 pipeline projects must be "required by the present or future public convenience and necessity" 154 - similar to the statutory requirement at issue in Michigan that regulation be "necessary and appropriate." Additionally, FERC generally has the tools to quantify and balance the consequences of its actions. As a result, if the costbenefit state continues to deepen, FERC risks that its decisions will be invalidated for failure to adequately consider costs and benefits.155 The Commission can insulate its actions from the risk of judicial skepticism by adopting cost-benefit analysis as a tool in its toolkit.

\section{FERC's Decisions Are Amenable to Cost-Benefit Analysis}

Academic literature has identified a number of reasons why certain regulatory agencies may not be prepared to use costbenefit analysis, including the prevalence of effects that are not amenable to quantification or monetization and the lack of institutional capacity to perform rigorous cost-benefit

${ }_{151}$ Sunstein, supra note 80, at 18-19.

152 See Indus. Union Dep’t, AFL-CIO v. Am. Petroleum Inst., 448 U.S. 607 (1980) (finding Congress prohibited Department of Labor from balancing costs and benefits when promulgating certain occupational safety and health standards); Sunstein, supra note 80 , at $19-20$.

15316 U.S.C. $\$ 824 d(a)(2018)$.

15415 U.S.C. $\S 717 f(\mathrm{e})(2018)$.

155 The recent judicial record on FERC's obligations to quantify the consequences of its actions has been mixed. See Sierra Club v. FERC, 867 F.3d 1357, 1374 (D.C. Cir. 2017) (faulting FERC for failing to quantify greenhouse gas emissions in a pipeline certificate decision); NextEra v. FERC, 898 F.3d 14, 23-24 (D.C. Cir. 2018) (rejecting challenge that FERC relied on economic theory rather than quantified economic impacts when approving new market rules). FERC is currently facing a challenge to a rulemaking that may provide the D.C. Circuit the opportunity to clarify FERC's obligations. See Br. of Intervenor Transmission Access Policy Group, at 11-16, Am. Pub. Power Ass'n v. FERC, No. 19-1147 (D.C. Cir. filed Nov. 6, 2019). 
analysis.156 However, these factors do not apply to FERC, which regulates a sector of the economy that is amenable to quantitative analysis and which has the institutional capacity to conduct or review such analysis.

First, the consequences that result from FERC actions are often of the type that can be readily incorporated into a monetized cost-benefit analysis. Many of the costs and benefits at issue in FERC decisions are market goods that are already valued in economic terms and are relatively straightforward to use in a cost-benefit analysis. 157 This includes the economic value of wholesale electricity, as represented by its price, the economic value of additional natural gas supply, the costs of transmission construction, and the consumer costs of paying for more generation capacity.

Analysis of some consequences of FERC regulation may require non-market valuation techniques. While this is more complex than the use of market data, much of the guidance on agency cost-benefit analysis is dedicated to techniques for calculating the value of non-market costs and benefits.158 Take, for example, the value that consumers place on the continuation of electric service in the face of disruptions-often called the value of lost load ("VOLL"). Because electricity prices for consumers are generally regulated, electricity market price data does not establish the value consumers place on reliability-that is, the value they place on avoiding outages. Economists have developed methodologies for estimating VOLL for different customer classes and outage lengths. 159 While there is no universally accepted single measure of VOLL, 160 FERC can

156 Revesz, supra note 8, at 554-56 (identifying and responding to concerns with use of cost-benefit analysis for regulation with substantial macroeconomic effects); $i d$. at 560 (discussing need to develop new methodological tools to evaluate costs and benefits for some regulatory consequences). See generally id. at 560-93 (discussing institutional shortcomings and recommendations for overcoming them).

157 See CiRCUlAR A-4, supra note 2, at 19 ("Market prices provide rich data for estimating benefits and costs based on willingness-to-pay if the goods and services affected by the regulation are traded in well-functioning competitive markets").

158 Id. at $19,21-25$.

159 See, e.g., MARK BURLINGAME \& PATty WALton, NARUC AND MDPSC Cost-BEnEFit ANALYSis of VARIOUS Electric RELIABILITy IMPROVEMENT PROJECTS FROM THE END USERS' PERSPECTIVE 13-62 (2013).

160 See London Economics InT'L, Estimating the Value of Lost LoAd 51 (2013), https://hepg.hks.harvard.edu/files/hepg/files/06_18_13_ercot_voll_literature_review_an d_macroeconomic_analysis_0613.pdf [https://perma.cc/2RH3-DMFZ] (reviewing VOLL 
exercise its expert judgment and use economic tools such as sensitivity analysis to incorporate VOLL into cost-benefit analyses of electric market regulation or new reliabilityenhancing energy infrastructure.

FERC decisions also produce significant non-market environmental consequences. Electric market rules and energy infrastructure can influence the amount of electricity produced by fossil fuel-fired generators, which produce air pollution including greenhouse gases. Infrastructure development also produces direct environmental consequences in the form of direct emissions of air pollutants, species habitat disruption, and changes in ecosystem services. 161 Methodologies are readily available to quantify and monetize these environmental consequences. EPA publishes extensive guidance for the valuation of a wide variety of environmental consequences, including the public health effects of air and water pollution.162 In 1998, the Fish and Wildlife Service commissioned a study evaluating how FERC could use existing tools to monetize ecosystem changes caused by infrastructure project permitting;163 and substantial progress has been made in these areas in the decades since.164

Another type of difficult-to-model effect is the macroeconomic effect of an agency's actions. However, FERC actions generally produce consequences that can be evaluated using microeconomic tools rather than more controversial macroeconomic modeling. Unlike financial regulation,165 FERC regulation largely sidesteps questions about the feasibility of determining costs and benefits based on macroeconomic

studies and finding a wide distribution of estimates based on location, customer profile, and methodology).

161 See U.S. FISH AND WILDLIFE SERVICE, supra note 67, at 3-16 to 3-20.

162 EPA, GUIDElines FOR PREPARING ECONOMIC ANAlyses 7-6-7-44 (2014), https://www.epa.gov/sites/production/files/2017-08/documents/ee-0568-50.pdf [https://perma.cc/LJJ9-936E].

163 See generally U.S. FISH AND WILDLIFE SERVICE, supra note 67.

164 See Revesz, supra note 53, at 1442-44 (describing the state of economic valuation of ecosystem services).

${ }_{165}$ See Revesz, supra note 8, at 554-55 (framing academic dispute regarding importance and feasibility of using macroeconomics in cost-benefit analysis of financial sector regulation and citing sources). 
effects.166 That is because the main effects of energy system regulation will be borne by energy system participants and, to some extent, third parties.

Another weakness that scholars have identified that may make effective cost-benefit analysis difficult for agencies-and in particular for independent agencies-is the lack of institutional capacity to perform such analyses.167 As Professor Richard Revesz explores, the establishment of an agency office dedicated to performing economic analyses, staffed with $\mathrm{PhD}$ economists and other experts, could significantly enhance an agency's ability to conduct adequate cost-benefit analyses. 168 While FERC's institutional capability is not as robust as agencies such as EPA, it does have expert staff that could be tapped to perform or evaluate cost-benefit analysis. In addition to FERC's offices dedicated to reviewing project applications and regulating rates, the Division of Economic and Technical Analysis within the Office of Energy Policy and Innovation employs twenty-five economists, engineers, and other technical experts 169 to "conduct[] economic, engineering and technical analysis in support of the Commission's review of industry proposals, which includes quantitative analysis of electricity and natural gas market data." 170 Of course, FERC's institutional capabilities can be strengthened. FERC could benefit from a partnership with OIRA,171 or could embark on a process similar

${ }_{166}$ Of course, because energy is a fundamental input to most economic activity, FERC actions that change energy prices can have significant macroeconomic consequences. Agencies are developing tools such as computable general equilibrium ("CGE") modeling to estimate and incorporate macroeconomic consequences into their cost-benefit analyses. Id. at 556-59. As these tools gain more widespread acceptance, they can be incorporated into FERC decision making. However, the primary costs and benefits of FERC regulation will be measurable through microeconomic modeling. ${ }_{167} I d$. 168 Id. at 569-70.

169 See Committee on Energy and Commerce Witness Disclosure Statement of J. Arnold Quinn at 2 (June 1, 2015), https://docs.house.gov/meetings/IF/IF03/20150603/ 103551/HHRG-114-IF03-TTF-QuinnJ-20150603.pdf [https://perma.cc/6ZSJ-WS62].

170 FERC, Division of Economic and Technical Analysis (last visited April 19, 2020), https://www.ferc.gov/about/offices/oepi.asp [https://perma.cc/7YWL-C2NZ].

171 See Office of Info. and Reg. Affairs \& U.S. Commodity Futures Trading Comm'n, Memorandum of Understanding (May 9, 2012), https://www.whitehouse.gov/sites/ whitehouse.gov/files/omb/inforeg/inforeg/regpol/oira_cftc_mou_2012.pdf [https://perma.cc/7EPM-B4Q4] (providing for OIRA technical assistance without triggering regulatory review requirements). 
to that taken by EPA as it developed cost-benefit expertise.172 Nonetheless, FERC already benefits from substantial in-house economic and technical expertise that could be deployed to develop or review cost-benefit analyses of its significant actions.

Cost-benefit analysis is a powerful tool to inform agency decision making. While FERC is not currently subject to clear obligations to use cost-benefit analysis in most circumstancesand it has not yet voluntarily adopted such a practice-doing so would significantly improve the quality and transparency of FERC's decision making, and will reduce both the legal and political risk that its decisions will be delayed or overturned. Particularly in light of the importance and political controversy surrounding FERC's role in the energy transition, now is the right time to embrace cost-benefit analysis as a decision making tool for significant decisions. In the next two Parts, this Article evaluates two types of decisions-electric market regulation and natural gas pipeline certificates-and concludes that costbenefit analysis would be legally and practically feasible.

\section{WholesAle ELECTRIC MARKET RULES}

One of the most important tasks that FERC will undertake as it guides the transition of the energy system is to approve and, when needed, direct changes to the rules that govern the operation of the wholesale electric markets. This Part considers the prospect for cost-benefit analysis to serve as a tool to evaluate potential electric market rules in order to balance competing interests between electricity producers and consumers and to approve those rules that enhance the efficiency of the markets and maximize social welfare, including, critically, by taking into account the ancillary consequences that market rules will have on climate change.

\section{A. FERC's Role and Current Approach}

This section provides an overview of FERC's role overseeing the wholesale electric markets and its past use of cost-benefit analysis to support its transformation of those markets. It then

172 Revesz, supra note 8, at 592-93. 
discusses FERC's current approach to evaluating and directing proposed changes to the rules that govern those markets.

1. FERC's Initial Transformation of the Electric System

Since 1935, the FPA has provided FERC (or its predecessor, the Federal Power Commission ("FPC")) with the responsibility of regulating the wholesale sale of electricity.173 Starting thirty years ago, FERC reinterpreted its traditional statutory authority to substantially restructure the electric industry in response to changes in technology, economy theory, and the law.174 This transformation involved two interrelated changes.

First, FERC reconceptualized its mandate under the FPA to ensure that the rates and terms of wholesale sales of electricity are "just and reasonable" and "not unduly discriminatory or preferential" 175 by determining that, so long as markets were sufficiently competitive, freely negotiated rates for the sale of wholesale electricity between buyers and sellers would be presumptively permitted.176 Second, FERC strongly encouraged the formation of organized wholesale markets in which the sale and dispatch of electric generation and associated energy services is centrally managed by an independent entity, called an RTO.177 There are now six RTOs that are regulated by FERC, which collectively cover a substantial majority of electric customers-the California Independent System Operator ("CAISO"), Midcontinent Independent System Operator ("MISO"), New England Independent System Operator ("ISONE"), the New York Independent System Operator, PJM Interconnection ("PJM"), and Southwest Power Pool ("SPP").178

Taken together, these changes mean that FERC's role in this new system is focused on establishing and approving generally applicable rules by which electric market participants operate,

17316 U.S.C. $\$ 824$ (a) (2018) (providing FERC with jurisdiction over "the transmission of electric energy in interstate commerce and to the sale of electric energy at wholesale in interstate commerce") (Emphasis added).

174 See David B. Spence, Can Law Manage Competitive Energy Markets, 93 CoRnell L. REV. 765, 769-70 \& n.21 (2008).

17516 U.S.C. $\S \S 824 d(d)$, (e) (2018).

176 See Order No. 888, supra note 12 , at 31,643 \& n.48 (describing the transition to market-based rates and listing early market-based rate cases).

177 See id. at 31,730-32 (defining characteristics of an ISO); Order No. 2000, supra note 13, at 31,046 (defining the characteristics of an RTO).

178 FERC, ENERGY PRIMER 59 (2015). 
rather than on policing the specific prices charged by and to those market participants.179 For most of the country, FERC does so by regulating RTO "tariffs" that function as the market rules that govern the behavior of generators, load, and other market participants. RTOs may submit changes to their market rules under FPA Section 205, which allows utilities to request FERC approve any rate, rule, or regulation affecting rates that is "just and reasonable" and "not unduly discriminatory or preferential." 180 FERC can also mandate changes to RTO market rules by initiating a proceeding under FPA Section 206, which requires FERC to hold unlawful any rate or rule affecting rates it deems to be unjust, unreasonable, or unduly discriminatory and authorizes FERC to fix a just and reasonable replacement.181

FERC generally exercises this authority on an individual RTO-by-RTO basis. However, FERC also imposes industry-wide requirements by implementing regulations after a notice of proposed rulemaking, that, pursuant to FPA Section 206, directs all RTOs to take actions to cure their unjust, unreasonable, or unduly discriminatory market rules.182

\section{Cost Benefit Analysis in a Supporting Role}

In managing the initial transition to competitive wholesale markets, FERC benefited from the use of cost-benefit analysis. Centralized operation of wholesale electric markets jumpstarted in 1996, when FERC issued its landmark Order 888, which required transmission owners to offer non-discriminatory provision of transmission service through the filing of "open access transmission tariffs." 183 Order 888 included a mechanism for the formation of independent entities that would operate the

179 Alco Finance Ltd. v. Klee, 861 F. 3d 82, 88-89 (2d Cir. 2017) ("RTOs and ISOs administer a number of competitive wholesale auctions. FERC extensively regulates the structure and rules of such auctions, in order to ensure that they produce just and reasonable results.").

18016 U.S.C. $\S \S 824 d(a)$, (b) (2018).

18116 U.S.C. $\S 824 \mathrm{e}(\mathrm{a})(2018)$.

182 Transmission Access Policy Study Grp. v. FERC (TAPS), 225 F. 3d 667, 687-88, 703

(D.C. Cir. 2000) (holding Section 206 provides FERC with authority to cure unjust, unreasonable, or unduly discriminatory rates through a rulemaking that applies across the power sector).

${ }_{183}$ See generally Order No. 888, supra note 12. 
electric system under principles of economic competition. 184 FERC used a cost-benefit analysis embedded in a final environmental impact statement ("FEIS") as a critical part of its justification for Order 888.185 FERC took the unusual step of preparing an FEIS,186 as a response to concerns that the market liberalization enabled by Order 888 would result in a significant increase in the operation of coal-fired power plants and, therefore, a significant increase in air pollution.187 As a result, FERC "prepared an FEIS based upon computer modeling simulations of power generation patterns and [nitrous oxide] emissions likely to occur as a result of the Rule."188 FERC's modeling took into account uncertainty and analyzed a number of alternative regulatory approaches. FERC acknowledged that preparation of the FEIS involved "a number of judgments as to the type and the scope of studies necessary to analyze the proposals sufficiently." 189 Ultimately, FERC concluded that Order 888 would not substantially affect the overall emission trends.190 But FERC's FEIS was not limited to an analysis of the environmental consequences of Order 888. It also included an analysis of the economic effects of the rule. This included $\$ 3.8$ to $\$ 5.4$ billion of expected consumer benefits that would result from increased competition in the electric industry.191 This information was useful for FERC's evaluation of the desirability of its proposed approach.192 It enabled FERC to address concerns raised by a number of commenters and other federal agencies in a systematic and transparent fashion. FERC also acknowledged that the analysis it performed was useful in informing regulatory alternatives for other agencies, including the EPA.193

184 Id. at $31,730-32$.

185 Order No. 888, supra note 12 , at $31,860$.

186 See 18 C.F.R. $\S 380.4(a)(15)$ (2020) (generally exempting ratemaking decisions from NEPA requirements).

187 Order No. 888, supra note 12 , at 31,860 .

$188 I d$.

$189 I d$. at 31,861 .

$190 I d$. at 31,862 .

191 Id. at 31,873 .

$192 I d$. at 31,865 ("Our FEIS clearly demonstrates that this Rule is not the appropriate vehicle for resolving" the issue of NOx emissions, but "we believe that our study makes a significant contribution nonetheless.").

${ }_{193} I d$. 
In 2000, FERC furthered restructuring when it issued Order 2000.194 Order 2000 strongly encouraged the formation of RTOs, and defined minimum features of an RTO.195 FERC also used a cost-benefit analysis to support Order 2000.196 Costs and benefits of RTO formation were analyzed in an Environmental Assessment ("EA") that FERC conducted pursuant to NEPA.197 The Order 2000 EA focused on an evaluation of the environmental consequences of the rulemaking, such as the effect of RTO market rules on emission of air pollutants. 198 However, the analysis also included monetized estimates of a subset of the benefits that the Commission expected would be produced by the rule.199 This included average annual consumer savings of $\$ 2.4$ to $\$ 5.1$ billion per year between 2000 and 2015.200 FERC used these monetized benefits as the basis for its evaluation of the desirability of the rule.201

In order to develop estimated costs and benefits of Order 2000, FERC evaluated "a broad range of potential economic changes that could result from the Rule" including "changes in the mix of electric generating plants built in the future, shifts in the utilization of existing plants, and increases in interregional transmission." 202 FERC developed a set of assumptions, informed by its expert judgment, regarding how various RTO market rules would affect the costs and physical properties of the electricity system. 203 FERC then used sophisticated computer models to simulate the resulting investment decisions

194 See Order No. 2000, supra note 13.

$195 I d$. at 30.

196 See id.

197 Id. at $39-40$.

198 Id. at 285-86 (discussing impacts on SO2, NOx, CO2, and mercury emissions).

199 Id. at $39-40$.

$200 I d$. at 40. FERC acknowledged that the modeling it conducted for the purposes of the EA did not capture a range of benefit categories such as reduction of market power, improved intra-regional congestion management. Id. The modeling also did not estimate important categories of costs, such as the cost of RTO formation, and the costs associated with incentives provided for the formation of RTOs. Id. However, FERC did discuss third-party studies of the costs of forming regional grid operators and concluded that these costs would be unlikely to outweigh the consumer savings benefits. Id.

$201 I d$. at 282 ("the modeling and analysis conducted for the EA are the basis for the economic discussion contained in the Final Rule"); id. at 39-40.

$202 I d$. at 281.

$203 I d$. at 283. 
and regional electric system operation.204 FERC recognized that its analysis was subject to significant uncertainty, but nonetheless "present[ed] a systematic view of possible future market changes and assesse[d] a range of possible responses to market changes." 205

In Order 2000, FERC did not require individualized costbenefit analyses as a condition of the formation of new RTOs.206 However, as the politically contentious process progressed in regions of the country without RTOs, stakeholders increasingly called on FERC to require or conduct cost-benefit analyses of individual RTOs.207 FERC eventually agreed to conduct a costbenefit analysis of RTO formation.208 FERC commissioned ICF International to conduct a cost-benefit analysis of RTO expansion ("RTO Study").209 Unlike the Order 888 EIS and Order 2000 EA, the RTO Study analyzed only the private costs and benefits of RTO design and did not include an analysis of social costs and benefits such as damages from air pollution.210 Nonetheless, the RTO Study found that the net benefits of RTO expansion were significant- $\$ 40$ billion from $2002-2021$ under the scenario deemed most likely to occur.211 Based on the results of the analysis, FERC ultimately issued its "Standard Market Design" notice of proposed rulemaking which proposed to

${ }_{204} I d$. ("Computer modeling capable of simulating regional electric utility dispatch and capacity expansion over time was used to characterize electric power markets in the base case and rule scenarios.").

$205 I d$. at 281.

206 Id. at $31,017,31,036$.

207 See Avista Corp., 95 FERC 9 61,114, at 61,324 (Apr. 26, 2001) (RTO West Declaratory Order); Ariz. Pub. Serv. Co., 101 FERC 9 61,033, at P 222 (Oct. 10, 2002) (WestConnect RTO Declaratory Order).

208 Electricity Market Design and Structure, Order Providing Guidance on Continued Processing of RTO Filings, 97 FERC \ 61,146 (Nov. 7, 2001). Nonetheless, FERC continued to approve RTOs without cost-benefit analyses. See Southwest Power Pool, 109 FERC \ 61,010, at P 12 (Oct. 1, 2004). See also Ariz. Pub. Serv. Co., 101 FERC ๆ 61,033, at P 222 (Oct. 10, 2002).

209 See ICF InT'L, Economic Assessment of RTO Policy (Feb. 26, 2002) [hereinafter RTO STUDY].

210 The RTO Study's estimate of private costs and benefits has been subject to substantial criticism, including that the assessment assumes that RTOs will cause significant improvement in the efficiency of electric generation but does not conduct an analysis that evaluates whether that assumption is likely. See Thomas M. Lenard, FERC's Flawed Assessment of the Benefits and Costs of Regional Transmission Organizations, THE ELECTRICITY J., May 2002, at 74.

211 RTO STUDY, supra note 209, at 77. 
require the formation of $\mathrm{RTOs}$ for all utilities that had yet to join an RTO and to more prescriptively define the design of wholesale electric market rules across existing and new RTOs. 212 The proceeding was ultimately closed without taking final action as a result of the substantial political backlash that the proposal engendered.213 The backlash that ended the Standard Market Design rulemaking also ended FERC's systematic use of costbenefit analysis in the context of RTOs.

\section{FERC's Current Approach to Policing Electric Market Rules}

While FERC used cost-benefit analysis in support of the prior transformation of the electric system, it has not continued its use when evaluating new changes to wholesale electric market rules.214 FERC does not regularly conduct cost-benefit analyses to evaluate market rule changes that it has proposed through rulemaking or when evaluating replacement rates after finding an individual RTO tariff to be unjust and unreasonable under Section 206. Nor does FERC generally require RTOs to submit cost-benefit analyses to justify market rule changes submitted pursuant to Section 205. FERC has repeatedly ignored or rejected requests by stakeholders that it require a cost-benefit

212 Remedying Undue Discrimination Through Open Access Transmission Service and Standard Electricity Market Design, 67 Fed. Reg. 55,452 (proposed Aug. 29, 2002), FERC Stats. \& Regs. ๆ 32,563 (July 31, 2002).

${ }_{213}$ Order Terminating Proceeding, 112 FERC $\uparrow$ 61,073 (July 19, 2005).

214 There is one identified exception. In 2004, FERC ordered MISO to provide further evidence regarding the expected net-benefits of a tariff revision. Midwest Indep. Transmission Sys. Operator, Inc, 107 FERC @ 61,191, at P 73 (May 26, 2004). In response, MISO utilized production cost and power flow modeling to conduct its economic analysis, which found that implementing proposed tariff changes would result in $\$ 128.4$ million in net benefits to direct market participants. Midwest Independent Transmission System Operator, Inc. Compliance Filing at 3, Docket No. ER04-691-000 (June 25, 2004), https://elibrary.ferc.gov/idmws/common/opennat.

asp?fileID=10176978. FERC relied on MISO's quantitative cost-benefit analysis, as well as a qualitative assertion of the "broader range of economic and reliability benefits that the Midwest ISO's market is designed to achieve" when approving MISO's tariff. Midwest Indep. Transmission Sys. Operator, Inc, 111 FERC $\$ 61,042, at P 175 (Apr. 15, 2005). FERC also exercised its own judgment, informed by MISO's economic analysis, to adopt changes to MISO's tariff filing. Midwest Indep. Transmission Sys. Operator, Inc, 108 FERC \ 61,236, at PP 99-100 (Sept. 16, 2004). 
analysis to justify selection of particular market design changes. 215

In fact, beyond specific narrow precedent, FERC does not use any consistent procedure or criteria to analyze and decide whether a particular market rule change is "just and reasonable." Its evaluation of whether a potential market rule change will be judged "just and reasonable" is often opaque. At times, FERC announces policy "principles" or "criteria" by which it will evaluate particular kinds of market rule changes. For example, in 2017, FERC approved a tariff filing by ISO-NE to revise its capacity market.216 As part of that proceeding, FERC announced a new set of policy principles by which it would evaluate future changes to capacity markets, including that such markets should "produce a level of investor confidence that is sufficient to ensure resource adequacy at just and reasonable rates." 217 But just a few months later, FERC rejected a filing by PJM Interconnection to change its capacity market that had been justified on the very principles FERC had enunciated in approving the changes to the ISO-NE market. 218 As Commissioner Richard Glick noted in dissent, "just three months later, the Commission appears to have settled on a new standard, the 'integrity' of the market."219 As another example,

215 See Wholesale Competition in Regions with Organized Electric Mkts., Order No. 719 A, 128 FERC - 61,059, at PP 89, 93 (Jul. 16, 2009) (rejecting request to require a costbenefit analysis to justify selection among potential shortage pricing approaches). In the advanced notice of proposed rulemaking initiating that proceeding, FERC solicited public input on ways to improve organized markets. Wholesale Competition in Regions with Organized Electric Markets, 72 Fed. Reg. 36,276 (proposed July 2, 2007). A number of commenters suggested that FERC adopt cost-benefit analysis as a decision making framework. See Comments of the Transmission Access Policy Study Group at 49, Docket Nos. RM07-19-000 and AD07-7-000 (Sept. 14, 2007) ("the Commission should require RTOs to assess the cost/benefits of new initiatives or major rule changes before undertaking them, taking into account both RTO costs and costs to market participants"); Comments of the Large Public Power Council at 20-22, Docket Nos. RM07-19-000 and AD07-7-000 (Sept. 14, 2007) ("With respect to significant tariff changes, cost-benefit analyses should be submitted with the RTO/ISO section 205 filings"). FERC ultimately ignored these requests. See also N.Y. Indep. Sys. Operator, Inc., 103 FERC I 61,201, at PP 35-36 (2003) (rejecting commenters' argument that "detailed supporting analyses or a cost-benefit study are necessary in order to support a finding that the Demand Curve is just and reasonable").

216 ISO New England, Inc, 162 FERC ๆ 61,205 (Mar. 19, 2018).

217 Id. at $\mathrm{P} 21$.

218 Calpine Corp. v. PJM Interconnection, LLC, 163 FERC \ 61,236 (June 29, 2018).

219 Id. at P 50 n.312 (Glick, Comm'r, dissenting). 
in Order 719, another order to improve competition in the wholesale market, FERC required RTOs to adopt market rule reforms to better account for the value of energy during periods when demand exceeds supply (termed "shortage pricing") and provided RTOs with four options to select from in designing their particular market rules to implement shortage pricing. FERC established six criteria by which it would evaluate each RTO's selection among the four options, with no clear standard regarding how it would balance these six criteria.220 In another case, FERC determined whether a market rule is just and reasonable based on whether the rule "produce[s] prices that accurately reflect the value of energy." 221

FERC has not delineated how it uses the principles or criteria to balance competing interests in any of these cases. Rather, FERC uses quantitative information,222 qualitative descriptions of costs and benefits it considers to be relevant,223 or economic theory,224 to explain its decisions on what appears to be an ad hoc basis. Even when FERC qualitatively describes costs and benefits of particular rules, it does not present or evaluate those costs and benefits in a systematic framework by which it can clearly balance competing interests. In fact, at times FERC has been actively hostile regarding cost-benefit analysis. FERC has considered economic analyses that were developed and submitted by stakeholders as part of its evaluation of whether a rule is just and reasonable.225 But this approach relies on often resource-constrained or self-interested stakeholders.

220 Wholesale Competition in Regions with Organized Electric Markets, Order No. 719, 125 FERC 9 61,071, at P 247 (Oct. 17, 2008).

221 Id. at $\mathrm{P} 192$.

222 See generally Order No. 888, supra note 12.

223 E. Ky. Power Coop., Inc. v. FERC, 489 F.3d 1299, 1307 (D.C. Cir. 2007) (discussing a FERC order that identified qualitative benefits of RTOs).

224 TAPS, 225 F.3d at 688 (upholding use of economic theory to support FERC action under Section 206).

225 See PJM Interconnection, LLC, 155 FERC \ 61157, at P 4 (May 10, 2016) (relying on an estimate of benefits of a particular capacity market design included in a formal costbenefit analysis submitted by a stakeholder). 
B. FERC Should Adopt an Expanded Cost Benefit Requirement

The electric system is undergoing another transition as a result of changes in technology and greater focus on climate change, and FERC should return to its brief practice when regulating the last energy system transition. The current transition will not require wholesale restructuring of the electric sector, but rather a series of rule changes to allow participation of new clean energy technologies. FERC should use cost-benefit analysis in not only foundational orders but also any major industry-wide rulemaking or RTO tariff filing that would substantially change the rules of the game. And, in light of the factors motivating the current industry transition-the need to tackle climate change coupled with concerns about maintaining the reliability and resilience of the electric system-any costbenefit analysis that FERC requires or conducts should include not only costs and benefits to producers and consumers but also ancillary costs and co-benefits that accrue to society as a whole. FERC can do so by formalizing a requirement that it will conduct a cost-benefit analysis as part of each Commission-initiated Section 206 proceeding to significantly change RTO market rules and by requiring RTOs to conduct and submit cost-benefit analyses as part of any Section 205 filing to significantly change electric market rules. While FERC's general approach can be the same, Sections 205 and 206 contain somewhat distinct procedural requirements that will influence the manner in which FERC uses cost-benefit analysis.

Cost-benefit analysis would be a valuable tool to inform FERC investigations into whether an existing market rule is "just and reasonable" under the procedures mandated by FPA Section 206. FERC's exercise of authority under Section 206 involves a two-step process.226 Before ordering a change in market rules, FERC must first determine that the existing rules are not just and reasonable.227 This step may be taken in response to a complaint by market participants, by interested members of the public, and in certain circumstances, by the RTO itself.228 FERC

226 Emera Me. v. FERC, 854 F.3d 9, 25 (D.C. Cir. 2017).

227 Id. at 21 .

${ }_{228}$ FirstEnergy Serv. Co. v. FERC, 758 F.3d 346, 348-49 (D.C. Cir. 2014). 
can also sua sponte find an individual RTO tariff to be unjust and unreasonable,229 or, through a rulemaking proceeding, find all RTO tariffs to be unjust and unreasonable.230 Only after making such a determination, supported by substantial evidence, may FERC then order RTOs to implement revised market rules.231 Those rules must be just and reasonable.

Cost-benefit analysis would be consistent with both of the steps of a Section 206 proceeding. FERC could use a cost-benefit analysis as the factual basis for finding that the market rules of one or more RTOs are unjust and unreasonable. As it did with Orders 888 and 2000, FERC can also use cost-benefit analysis to evaluate potential market rule replacements it is considering. A cost-benefit analysis would provide FERC with the information it needs to select the option that maximizes social welfare as a just and reasonable replacement.

FERC's use of cost-benefit analysis in the context of filings made under Section 205 of the FPA present some additional complications as compared to its use in Section 206 proceedings. These complications, however, need not be barriers to the use of cost-benefit analysis to inform FERC's decision to approve or deny an RTO's proposal to change its market rules.

Under Section 205, an RTO proposes changes to its own market rules. FERC plays "an essentially passive and reactive role" 232 in which it must accept proposed changes so long as they are just and reasonable and not unduly discriminatory and preferential. 233 Utilities are not required to show that the existing rate or market rules are unlawful.234 However, FERC still must affirmatively decide that an RTO's proposal is just and reasonable. As explained in the next section, FERC is well within its statutory authority to rely on cost-benefit analyses to make such a determination.

$229 \mathrm{Id}$.

230 TAPS, 225 F.3d at 687-88 (holding that under Section 206, FERC has authority to require industry-wide changes by rulemaking).

231 Erma Maine v. FERC, 854 F.3d 9, 25 (D.C. Cir. 2017).

232 City of Winnfield, La. v. FERC, 744 F.2d 871, 876 (D.C. Cir. 1984).

233 NRG Power Mktg., LLC v. FERC, 862 F.3d 108, 113 (D.C. Cir. 2017) ("FERC must accept proposed rate changes filed under Section 205 so long as the changes are just and reasonable.").

${ }_{234}$ Ala. Power Co. v. FERC, 993 F.2d 1557, 1571 (D.C. Cir. 1993). 
In fact, FERC can rely on its Section 205 authority to require submission of a cost-benefit analysis as a condition of approval of tariff changes.235 FERC has, on limited occasions, conditioned approval of individual RTO filings on submission of a costbenefit analysis in the past.236 Adopting a clear and consistent presumption that a cost-benefit analysis is a minimum requirement of a just and reasonable tariff change filing, 237 will assist FERC in complying with the restriction on the amount of time that FERC is permitted to evaluate an RTO's proposal. Under Section 205, FERC is required to act on tariff filings within 60 days, which may be extended by up to five months in order to hold hearings.238 By imposing a clear requirement that RTO filings must be accompanied by a cost-benefit analysis, FERC can meet its statutory deadlines and still benefit from transparent accounting of the costs and benefits of a proposal. Imposing such a requirement can also help FERC avoid a situation where an RTO's Section 205 filing goes into effect "by operation of law" and not based on the considered judgment of the Commission.239 Such a concern is not merely hypothetical. Recently, a significant and controversial change to ISO-NE's tariff to provide additional compensation to generators with onsite fuel went into effect because FERC lacked a quorum to disapprove the change, 240 even though FERC staff had expressed concern that ISO-NE had failed to sufficiently show that the benefits were justified by the costs.241 Adding a formal requirement that significant $\mathrm{RTO}$ tariff changes include a costbenefit analysis can help avoid this circumstance.

${ }_{235}$ Me. Pub. Utilities Comm'n v. FERC, 454 F.3d 278, 285 (D.C. Cir. 2006) (permitting FERC to impose conditions on RTO changes even though "the right to set rates in the first instance is a statutory right of utilities") (citations and quotations omitted).

${ }_{236}$ See case and text cited supra note 214.

237 See 18 C.F.R. $\S 35.13$ (establishing minimum filing requirements); id. $\S 35.5$ (providing authority for FERC to reject a filing that fails to comply with filing requirements).

23816 U.S.C. $\S \S 824 d(d),(e)(2018)$.

${ }_{239}$ Id. ("If the proceeding has not been concluded and an order made at the expiration of such five months, the proposed change of rate, charge, classification, or service shall go into effect at the end of such period"). See also Notice of Filing Taking Effect by Operation of Law, ISO New England Inc., Docket No. ER14-1409-000 (Sept. 16, 2014).

240 See Statement of Commissioner Glick, Docket No. ER19-1428-001 (Aug. 8, 2019).

${ }_{241}$ Letter from Kurt M. Longo, Director, Division of Electric Power Regulation to ISO

New England Inc. regarding Inventoried Energy Program, Docket No. ER19-1428-001 (May 8, 2019). 
By quantifying the expected results of market rule changes and by placing those results in a common metric-dollarsFERC can facilitate the transparent comparison and weighing of costs and benefits. But not all costs may be quantifiable. Consistent with OMB guidance 242 and past FERC practice, 243 RTOs or FERC should present and discuss any non-quantifiable and non-monetized costs and benefits as part of its cost-benefit analysis. Presenting quantified and unquantified costs and benefits together will facilitate the exercise of FERC's expert judgment to evaluate whether the unmonetized costs and benefits are substantial enough to change its decision regarding whether a market rule is just and reasonable.

\section{Statutory Authority}

Congress tasked FERC with ensuring that rates for the wholesale sale of electricity, and the rules affecting those rates, are "just and reasonable" and not "unduly discriminatory or preferential."244 These capacious terms provide FERC with the statutory authority-and, under the Supreme Court's decision in Michigan, potentially the obligation-to use cost-benefit analysis as its decision making framework, and to approve RTO market rule changes based on the information provided in such analyses.

First, this section describes how the just and reasonable standard by which FERC evaluates RTO market rules is consistent with the use of cost-benefit analysis. It then evaluates the scope of costs and benefits that FERC is permitted to consider in a cost-benefit analysis pursuant to its authority under the FPA.

${ }_{242}$ CiRCUlar A-4, supra note 2, at 27 ("If monetization is impossible, explain why and present all available quantitative information.”).

243 Order No. 888, supra note 12 , at 31,873 (identifying non-quantifiable benefits including "better use of existing assets and institutions, new market mechanism, technical innovation, and less rate distortion"); FERC, Promoting Wholesale Competition Through Open Access Non-discriminatory Transmission Services By Public Utilities (RM95-8-000) and Recovery of Stranded Costs by Public Utilities and Transmitting Utilities (RM94-7-001): Final Environmental Impact Statement at 5-64 to 5-75 (1996) (describing and analyzing the qualitative benefits).

24416 U.S.C. $\S \S 824 d(a)$, (b); 16 U.S.C. $§ 824 \mathrm{e}(\mathrm{a})$. 
1. Cost-Benefit Analysis and the Just and Reasonable Standard

Courts have held that whether a rate is "just and reasonable" is "incapable of precise judicial definition." 245 As a result, courts "afford great deference to the Commission in its rate decisions.”246 This deference applies to FERC evaluation of RTO market rules just as it did to FERC evaluation of cost-of-service rates and bilateral contracts.247 In fact, in its landmark decision under an analogous provision of the NGA,248 the Supreme Court held in Federal Power Commission v. Hope Natural Gas Co. that whether a rate is "just and reasonable" is a function of "the result reached, not the method employed." 249 "Congress clearly intended to allow the Commission broad discretion in regard to the methodology of testing the reasonableness of rates." 250 Given the breadth of FERC's authority when setting rates and rules affecting rates-including RTO market rules-the just and reasonable standard provides no barrier to FERC's use of costbenefit analysis.

At the same time, the Supreme Court has spoken approvingly of the Commission's interpretation that a just and reasonable rate should be determined by "balancing of the investor and the consumer interests." 251 Cost-benefit analysis is a method that facilitates this balancing and, as a result, is consistent with

245 Morgan Stanley Capital Grp. Inc. v. Pub. Util. Dist. No. 1 of Snohomish Cty., Wash., 554 U.S. 527, 532 (2008). Because courts have conceived of just and reasonable rates as those within a "zone of reasonableness," see In re Permian Basin Area Rate Cases, 390 U.S. 747, 767 (1968) (citing Fed. Power Comm'n v. Nat. Gas Pipeline Co., 315 U.S. 575 (1942), there is no single rate that meets the definition). 246 Morgan Stanley, 554 U.S. at 532.

${ }_{247}$ FERC v. Elec. Power Supply Ass'n, 136 S. Ct. 760, 782 (2016) (deferring to prescriptive RTO market-rule changes on the basis that "[W]e afford great deference to the Commission in its rate decisions." (citing Morgan Stanley, 554 U.S. at 532)).

248 When evaluating whether a rate is just and reasonable, "judicial interpretations of the FPA and the NGA may be followed interchangeably." Erma Me., 854 F.3d at 20 (citing Ark. La. Gas Co. v. Hall, 453 U.S. 571, 577 n.7 (1981); City of Anaheim v. FERC, 558 F.3d 521, 523 n.2 (D.C. Cir. 2009)).

249 Fed. Power Comm'n v. Hope Nat. Gas Co., 320 U.S. 591, 602 (1944).

250 Am. Pub. Power Ass'n v. Fed. Power Comm'n, 522 F.2d 142, 146 (D.C. Cir. 1975) ("Congress carefully eschewed tying 'just and reasonable' rates to any particular method of deriving the rates. Certainly there is nothing in the [FPA] specifically endorsing historic test year ratemaking or any other technique of ratemaking.").

${ }_{251}$ Hope, 320 U.S. at 603. 
FERC's authority to approve or reject RTO market rules as just and reasonable.

In addition to the substantive standard, FERC also has an evidentiary burden to make determinations about RTO market rules on the basis of a record supported by substantial evidence. ${ }^{252}$ Substantial evidence can include the use of economic models to inform whether a particular rate or rule is just and reasonable.253 The use of modeling to anticipate market outcomes and calculate expected costs and benefits from changes in market rules provides critical information for FERC to consider as it evaluates those proposed changes.254 The use of tools such as the Value of Lost Load can provide information on co-benefits of a rule change. Together, this information will assist FERC in meeting its obligation to act only on the basis of substantial evidence.255

Caselaw reinforces FERC's legal authority to use cost-benefit analysis as a tool to evaluate whether market rules are just and reasonable. In the 2001 case Public Utility District No. 1 of Snohomish County v. FERC, the D.C. Circuit recognized that a cost-benefit analysis could serve as an important factual basis for evaluating potential market rule changes. 256 That case considered a challenge to Order 2000 by petitioner Snohomish Public Power District. In Order 2000, FERC had found that, in

${ }_{252}$ S.C. Pub. Serv. Auth. v. FERC, 762 F.3d 41, 65 (D.C. Cir. 2014). While the court determined that FERC is not required to use "empirical evidence" or "to conduct experiments," id., empirical evidence developed through reasonable modeling can help justify FERC's decision making. See Wis. Gas Co. v. FERC, 770 F.2d 1144, 1158 (D.C. Cir. 1985) ("unsupported or abstract allegations of the benefits that will accrue from increased competition cannot substitute for 'a conscientious effort to take into account what is known as to past experience and what is reasonably predictable about the future.”) (quoting Am. Pub. Gas Ass'n v. Fed. Power Comm'n, 567 F.2d 1016, 1037 (D.C. Cir. 1977)).

253 Erma Me., 854 F.3d at 20 ("Because '[r]atemaking ... is not a science,' however, FERC must use models 'to inform, not rigidly to determine, [its] judgment"' (quoting Bos. Edison Co. v. FERC, 885 F.2d 962, 969-70 (1st Cir. 1989)).

${ }_{254}$ See TransCanada Power Mktg. v. FERC, 811 F.3d 1, 11-13 (D.C. Cir. 2015) ("TransCanada points out that, in approving the Program, FERC relied on a record that is devoid of any evidence regarding how much of the Program cost was attributable to profit and risk mark-up. TransCanada reasonably contends that, without this information, FERC could not properly assess whether the Program's rates were just and reasonable.").

${ }_{255}$ Ameren Servs. Co. v. Midwest Indep. Transmission Sys. Operator, Inc., 121 FERC $q$ 61,205 , at P 32 (2007).

${ }_{256}$ See Pub. Util. Dist. No. 1 of Snohomish Cty. v. FERC, 272 F.3d 607 (D.C. Cir. 2001). 
general, the formation of an RTO would be net-beneficial, but did not require potential RTOs to include a specific cost-benefit analysis in their compliance filings. In its petition challenging Order 2000, Snohomish argued that without a cost-benefit analysis, FERC could not reasonably determine that a proposed RTO was just and reasonable as required by FPA Section 205.257 The D.C. Circuit found that because Order 2000 required only the submission of an RTO proposal, and did not require or approve the formation of an RTO, Snohomish's objection to Order 2000 was not judiciable at that time.258 However, in reaching its decision that Snohomish was not yet harmed, the court relied on the fact that under the FPA, FERC would be required to consider any cost-benefit analysis that was submitted in the docket before making any final decision regarding the RTO. 259 The court also approvingly cited an agreement by the prospective RTO to conduct and submit a costbenefit analysis in support of its section 205 filing.260 As such, the D.C. Circuit's opinion in Snohomish would be inconsistent with reading the FPA to prohibit FERC's reliance on a costbenefit analysis to evaluate whether market rule changes submitted pursuant to Section 205 can be considered just and reasonable.

A more recent case in the D.C. Circuit provides further support for reading FERC's decision-making authority under the just and reasonable standard to include use of cost-benefit analysis to balance competing interests. In Advanced Energy Management Alliance v. FERC,261 the D.C. Circuit considered claims that FERC had failed to adequately consider the costs and benefits of a proposal by PJM to revise its capacity market rules and so had failed to meet its burden to show that the changes were just and reasonable. The court rejected this

257 Id. at 618

258 Id. ("Order 2000 is but a preliminary step . . . . If Snohomish's general argument stood alone we would dismiss its petition for lack of "aggrievement.").

259 Id. at 619 ("[T]he Commission must-in order to comply with the [FPA] and the Administrative Procedure Act-adequately address Snohomish's specific cost-benefit evidence (if Snohomish presents it) prior to the Commission's final decision on the RTO proposal.").

260 Id. ("RTO West is itself undertaking its own cost-benefit analysis of the proposal. The short of the matter is that in the site-specific proceeding, Snohomish may accomplish all it set out to accomplish in the rulemaking.").

261 See Advanced Energy Mgmt. All. v. FERC (ÂEMA), 860 F. 3d 656 (D.C. Cir. 2017). 
challenge but, in the process, relied on the fact that FERC had "balanced the benefits of the revised rules against the increased costs and reached a reasoned judgment" that the benefits justified the costs.262 Citing to the Supreme Court's decision in Michigan, the court suggested that consideration of both costs and benefits was required under the FPA.263 And the court approvingly cited to the fact that the Commission had, in fact, relied on a formal cost-benefit study submitted by a stakeholder, Exelon.264

\section{The Scope of Costs and Benefits FERC May Consider}

That FERC has authority to explicitly consider the monetized costs and benefits of an RTO market change does not, itself, answer the question of the scope of benefits and costs that FERC may consider. In order to maximize social welfare to the greatest degree possible, any quantitative or qualitative analysis that FERC requires or conducts should include as broad a scope of costs and benefits as FERC is permitted to consider under the FPA.

FERC is clearly obligated to balance the interests of consumers and investors when determining if a rate is just and reasonable.265 In order to facilitate such balancing, FERC's costbenefit analysis should evaluate costs and benefits to both

262 Id. at 660 (citing Blumenthal v. FERC, 552 F.3d 875, 885 (D.C. Cir. 2009)).

${ }_{263} I d$. at 662. The use of cost-benefit analysis as a tool does not preclude the Commission from exercising its judgment to approve or deny a market rule change based on unquantified factors. In AEMA, the D.C. Circuit explained that FERC "does not have to find net savings" and that courts will "defer to the Commission's weighing of the various considerations and ultimate "policy judgment." Id. at 662 (citations omitted). Therefore, a decision to quantify and monetize costs and benefits when feasible does not lock the Commission in to acting only based on quantified and monetized costs and benefits. However, to the extent unquantified costs or benefits lead FERC to adopt or reject a market rule as just and reasonable, FERC will have to explain why those costs or benefits were decisive. See TransCanada Power Mktg., 811 F.3d at 13 ("when the Commission chooses to refer to non-cost factors in ratesetting, it must offer a reasoned explanation of how the relevant factors justify the resulting rates. Here, the Commission did not explain what its balancing entailed, or how it applied the non-cost factors.") (internal citations and quotations omitted).

${ }_{264} A E M A, 860$ F.3d at 662 ("On rehearing the Commission cited a formal cost-benefit analysis, the Exelon study, which concluded that the new market rules would have net savings of between $\$ 900$ million and $\$ 4.7$ billion annually, starting in 2016." (citing PJM Interconnection, L.L.C., 155 FERC $₫$ 61,157, at P 34 (2016)).

265 Morgan Stanley Capital Grp. Inc. v. Pub. Util. Dist. No. 1, 554 U.S. 527, 532 (2008)

(citing Fed. Power Comm'n v. Hope Nat. Gas Co., 320 U.S. 591, 603 (1944)). 
investors and consumers. However, despite concerns that FERC has expressed in a number of contexts, FERC's ratemaking authority allows it to consider a broader scope of costs and benefits beyond just those accruing to investors and consumers. Put another way, consistent with the direction in Circular A-4, FERC can consider certain ancillary costs and benefits-e.g., environmental consequences-when establishing and approving RTO market rules and, as a result, those ancillary costs and benefits should be included in any cost-benefit analysis used to support a market rule.266

As the Supreme Court determined in the 1956 case Federal Power Commission v. Sierra Pacific Power Co., "the purpose of the power given the Commission by $\S 206$ (a) is the protection of the public interest, as distinguished from the private interests of the utilities," and so the requirement that rates be just and reasonable must be "read in the light of this purpose." 267 This language makes clear that FERC may not look only at the interests of utilities, and must also take into account the interest of energy consumers. It also suggests that FERC has authority to look to a broad scope of costs and benefits - those bearing on the public interest. Subsequent case law both affirmed and narrowed the scope of costs and benefits that permissibly fit under the "public interest" rubric. For example, in 1973, the Supreme Court decided, in Gulf States Utilities Co. v. Federal Power Commission, that a relevant component of the public interest that the Commission can consider when acting under Sections 205 and 206 is "the anticompetitive effects of interstate regulated utility operations.” 268

Yet, that FERC has authority to consider the public interest does not mean its authority is unbounded. There are likely costs and benefits that would fall outside of FERC's authority to act upon and so may not be relevant for a cost-benefit analysis.

Shortly after the Supreme Court expanded the "public interest" in Gulf States, it considered just how far that authority ran when acting under Sections 205 and 206, among other provisions. That case, NAACP v. Federal Power Commission, involved a question of the Commission's authority to mandate

266 Circular A-4, supra note 2, at 26.

267 Fed. Power Comm'n v. Sierra Pac. Power Co., 350 U.S. 348, 355 (1956).

268 Gulf States Utils. Co. v. Fed. Power Comm'n, 411 U.S. 747, 749 (1973). 
non-discrimination policies within the context of its regulation of electric and natural gas utilities. 269 The Court held that Congress's intent that ratemaking be in the public interest did not give FERC "a broad license to promote the general public welfare." 270 Rather, the factors that FERC may consider extended only to those factors that bear on the specific purposes of the acts the Commission administers. Because the purposes of electric utility regulation primarily involves "encourage[ing] the orderly development of plentiful supplies of electricity . . a at reasonable prices," 271 the Court held that the Commission clearly has authority to regulate non-discrimination policies if it finds that discrimination directly affects the rates that a utility charges its customers-such as by increasing costs to consumers. 272 However, absent such a finding, nondiscrimination was not an independent purpose of the FPA.

One set of costs and benefits that may be outside of FERC's ratemaking authority concerns those which result from a particular use of electricity. In Hope, the Supreme Court explained that the ratemaking authority under an analogous provision of the NGA did not permit the Commission to take into account the downstream uses of the commodity whose rates the Commission was regulating. The Court explained "we fail to find in the power to fix 'just and reasonable' rates the power to fix rates which will disallow or discourage resales for industrial use." 273 If the Commission is not empowered to take into account the costs and benefits of how electricity will be used, there would be little purpose in evaluating those costs and benefits as part of a cost-benefit analysis of RTO market rules. 274 Such a restriction may limit the usefulness of a macroeconomic evaluation of how a market rule will affect the broader economy. 275

269 NAACP, 425 U.S. 662.

$270 \mathrm{Id}$. at 669.

271 Id. at $669-71$.

$272 I d$. at 668 ("the Commission clearly has the duty to prevent its regulates from charging rates based upon illegal, duplicative, or unnecessary labor costs."). 273 Fed. Power Comm'n v. Hope Nat. Gas Co., 320 U.S. 591, 616-617 (1944).

${ }_{274}$ Cf. Dep't of Transp. v. Pub. Citizen, 541 U.S. 752, 766 (2004) (finding that environmental analysis under NEPA is not required if an agency is not empowered to act on the basis of that information).

275 See Part II(c)(5) for a discussion of microeconomic vs. macroeconomic modeling when evaluating costs and benefits. 
On the other hand, ensuring reliability and resilience are clear purposes of FERC regulation of the electric system. FERC has long interpreted its authority under Sections 205 and 206 to allow it to consider whether particular market rules will enhance or detract from the reliability of the electric system.276 Recently, FERC affirmed that this authority extended to evaluation of market rule changes on the resilience of the electric system.277

One important category of costs and benefits deserves further evaluation: the environmental consequences of electricity generation. In short, despite some suggestions to the contrary, FERC has the legal authority to consider environmental consequences in its evaluation of RTO market rules. FERC has previously taken the position that environmental concerns are not generally relevant for its evaluation of whether wholesale electric rates are just and reasonable. In Monongahela Power Co., FERC considered a Natural Resources Defense Council ("NRDC") challenge to a bilateral wholesale sale of electricity and capacity from a coal fired power plant.278 NRDC argued that FERC had erred in approving the transaction without producing an EIS that evaluated how the transaction would influence the amount of air pollution emitted by the coal plant.279 NRDC argued that the information produced in the EIS would "assist the Commission in deciding whether to approve" the wholesale sale.280 FERC determined that such information would not be helpful to the Commission's decision because neither Section 205 nor 206 provides FERC authority to deny a proposed rate based on whether the rate will lead to an increase in air pollution.281 As a result, FERC concluded that NEPA did not require an EIS for ratemaking actions under the FPA.282

\footnotetext{
276 See Gainesville Util. Dep't v. Fla. Power Corp., 402 U.S. 515, 529 (1971) (the Commission has the "responsibility to the public to assure reliable efficient electric service"); ISO New England Inc., 164 FERC ๆ 61,003, at P 49 (2018) (finding ISO-NE tariff may be unjust and unreasonable due to concerns about fuel security that pose a threat to electric reliability).

277 Resilience Order, supra note 117, at 13.

278 Monongahela Power Co., 39 FERC \ 61,350, reh'g denied, 40 FERC \ 61,256 (1987).

$279 I d$. at 62,092 .

$280 I$.

281 Id. at 62,097 .

282 Id. Citing its decision in Monongahela, FERC subsequently codified a "categorical
} exclusion," which allows it to generally forgo NEPA analysis when issuing decisions 
FERC's general view was affirmed by the D.C. Circuit in Grand Council of Crees v. FERC. 283 That case involved a challenge to a FERC order allowing a hydroelectric generator to sell at market-based rates. Petitioners argued that FERC had failed to consider the environmental effects of increasing hydroelectric generation. The court held that petitioners lacked prudential standing to raise these challenges because environmental protection is not an enumerated purpose of the FPA for the purpose of evaluating whether a particular energy marketer's rate is "just and reasonable." 284

At first blush, these cases suggest that environmental consequences are not factors that FERC may consider. However, there are a number of reasons why FERC may nonetheless consider environmental consequences when evaluating electric market rules.

First, while FERC has historically taken a narrow view of the environmental analysis it is required to conduct when evaluating rates under Sections 205 and 206, the language at issue in the FPA related to "just and reasonable rates" is ambiguous. None of the "traditional tools of statutory construction" compel a reading that excludes environmental considerations. In fact, the only court decision that has considered whether environmental considerations may be incorporated into an evaluation of whether a rate or rule is "just and reasonable," Grand Council of Crees, specifically deferred to FERC on the basis that the language at issue is ambiguous.285 As a result, under the familiar Chevron doctrine, FERC could change course and adopt an interpretation of "just and reasonable" that provides it jurisdiction to consider environmental consequences.286 This is true even in the face of

under FPA Sections 205 and 206. Regulations Implementing National Environmental Policy Act of 1969, 52 Fed. Reg. 47,897, 47,900 (Dec. 17, 1987) (codified at 18 C.F.R. $\S 381.4(\mathrm{a})(15))$.

283 Grand Council of the Crees v. FERC, 198 F.3d 950, (U.S. App. D.C. 2000).

284 Id. at $956-57$.

285 Id. at 957 (deferring to FERC's interpretation of "just and reasonable" to exclude environmental considerations pursuant to Chevron).

286 See TAPS, 225 F.3d at 687 ("the deferential standard of Chevron U.S.A. Inc. $v$. Natural Resources Defense Council, 467 U.S. 837, (1984), governs our review of FERC's interpretation of FPA [sections] 205 and 206.”); City of Arlington v. F.C.C., 569 U.S. 290 (2013) (holding that agencies are granted Chevron deference regarding their determination of their own jurisdiction). For an extended argument that the ambiguities 
a seemingly contrary judicial decision in Grand Council of Crees because the court in that case merely affirmed FERC's reading and did not claim that the "just and reasonable" language "leaves no room for agency discretion." 287

Second, FERC's own regulatory precedent suggests that the Commission can take into account environmental consequences when evaluating whether a potential market rule is just and reasonable. Monongahela and subsequent cases primarily concern FERC's obligations under NEPA. FERC has promulgated regulations that outline a process for overcoming the presumption that ratemaking will not have a significant environmental effect. 288 FERC has acknowledged that ratemaking can have a significant environmental effect that would require a NEPA analysis. 289 In Order 888, FERC acknowledged that it "ha[s] an obligation under NEPA to take the environmental consequences of our actions into account in fashioning our decisions" and considered the environmental consequences of its Order.290 That is, FERC recognized that it has legal authority to evaluate the environmental consequences of an action taken pursuant to Sections 205 and 206 and to act in ways informed by those consequences. FERC drew a distinction between incorporating the environmental consequences of its action into its evaluation of a particular market change-which it determined it had authority to doand imposition of separate requirements intended to mitigate those consequences, such as emission taxes or limits-which it determined were outside its statutory authority.291 The D.C. Circuit ultimately upheld the reasonableness of FERC's

in the statutory phrase "just and reasonable" provide FERC the opportunity to incorporate environmental costs and benefits into its evaluation of rates under Sections 205 and 206, see Bateman \& Tripp, supra note 120, at 300-311.

287 Nat'l Cable \& Telecomms. Ass'n v. Brand X Internet Servs., 545 U.S. 967, 982 (2005). 28818 C.F.R. $\S 380.4(b)$ (2018).

289 The Commission has invoked the exception and conducted environmental reviews when evidence has been presented that a decision normally subject to a categorical exclusion would significantly affect the environment. See, e.g. S. Cal. Edison Co. \& San Diego Gas \& Elec. Co., 49 FERC $\uparrow$ 61,091, 61,357 (Oct. 27, 1989).

290 Order No. 888, supra note 12 , at 31,864 .

291 Id. at 31,887 ("The discretion to consider public policy matters is a far cry from the authority, or obligation, to regulate those matters. We have considered the environmental impact of the rule"). 
environmental analysis. 292 In effect, FERC determined, consistent with Circular A-4, that it had authority to consider environmental consequences of ancillary costs or benefits, and the D.C. Circuit deferred.

Third, FERC's authority to incorporate environmental costs and benefits into its analysis and to accept or reject filings based on those costs and benefits is on particularly firm ground for market rule changes implemented by RTOs. This is because Congress specifically enumerated environmental concerns as a purpose of a key FPA section used to regulate RTOs: Section 202(a).

Section 202(a) of the FPA provides FERC the authority to create voluntary regional districts that coordinate the generation and transmission of electricity. When issuing Order 2000, encouraging the creation of RTOs, FERC relied on Section 202(a) (in addition to Sections 205 and 206). 293 The D.C. Circuit's approval of Order 2000 also relied, in part, on FERC's citation to its authority under Section 202(a).294

Section 202(a) reads, in relevant part:

For the purpose of assuring an abundant supply of electric energy throughout the United States with the greatest possible economy and with regard to the proper utilization and conservation of natural resources, the Commission is empowered and directed to divide the country into regional districts for the voluntary interconnection and coordination of facilities for the generation, transmission, and sale of electric energy.295

To the extent that FERC may consider only those costs and benefits of market rule changes that fulfill the purposes of the FPA, FERC action under Sections 205 and 206 with regard to RTO market rule changes should be read in light of the purposes

292 TAPS, 225 F.3d at 737. The court explicitly did not "resolve the parties' debate about FERC's legal authority to order environmental mitigation." Id.

293 Order No. 2000, supra note 13, at 31,044-45.

${ }_{294}$ Pub. Util. Dist. No. 1. of Snohomish Cty. v. FERC, 272 F.3d 607, 612-615 (D.C. Cir. 2001) (relying on the fact that FERC used Section 202(a), which permits FERC to approval regional coordination on a voluntary basis, to uphold Order 2000).

29516 U.S.C. $§ 824 a(a)$ (2018) (emphasis added). 
of Section 202(a).296 Beyond the promotion of plentiful supplies of electricity, Section 202(a) identifies a number of additional purposes with respect to voluntary coordination districts like RTOs. One such purpose is ensuring that the supply of electricity is made with "the greatest possible economy" - that is, that market rule designs should be economically efficient. 297 Another purpose of coordinated operation is "proper utilization of and conservation of natural resources." 298 This purpose can reasonably be read to allow FERC to take into account environmental considerations when evaluating potential RTO market rules.299

In fact, Commissioners have acknowledged that FERC has authority to consider factors beyond the impact on market participants in the context of regional entities created pursuant to Section 202(a) that may exceed its authority in other contexts.300 So too have the courts.301 As such, even under the limits imposed by NAACP and subsequent cases, the purposes of Section 202(a)—enhancing efficiency of the system and

${ }_{296}$ Cent. Iowa Power Coop. v. FERC, 606 F.2d 1156, 1168 (D.C. Cir. 1979) ("We agree with South Dakota that the Commission should consider the policies of the [FPA] [in Section 202(a)] in making a determination under [Section 206].”).

297 For an extended discussion about FERC's long-standing actions to improve the efficiency of markets, and the implications for market rules that efficiently price externalities from climate change, see Bethany A. Davis Noll \& Burcin Unel, Markets, Externalities and the Federal Power Act: The Federal Energy Regulatory Commission's Authority to Price Carbon Dioxide Emissions, 27 N.Y.U. ENVTL. L.J. 1 (2019).

29816 U.S.C. $\S 824 a(a)$ (2018).

299 Note that FERC has not, to date, interpreted Section 202(a) to require it to incorporate environmental considerations directly into its evaluation of RTO market rules. See, e.g., Cal. Indep. Sys. Operator Corp., 93 FERC - 61,001, 61,003 (Oct. 2, 2000) (rejecting a rehearing request that FERC failed to fulfill its duty to consider environmental consequences of reliability-must-run provisions, citing Monogahela, Crees). However, FERC may be permitted to incorporate environmental consequences into a cost-benefit analysis even if it is not required to do so. Id. ("In rejecting Petitioner's environmental claims in this case, the Commission did not, as Petitioner maintains, conclude that such factors were beyond its authority to consider under Sections 203 or 205 of the FPA and thereby summarily dismiss them.").

300 See S. Cal. Edison Co. \& San Diego Gas \& Elec. Co., 49 FERC ๆ 61091, 61,365 (Trabandt, Comm'r, dissenting in part) (rejecting inclusion of environmental factors in merger decisions made pursuant to Section 203 of the FPA but acknowledging that "section 202(a) gives the Commission authority to promote conservation through creating co-ordination districts.").

301 See e.g., Richmond Power \& Light of City of Richmond, Ind. v. FERC, 574 F.2d 610, 617 n.22 (D.C. Cir. 1978) (based on the language in Section 202(a) "one might reason that the Commission is empowered to consider overall fuel-supply economics and the social consequences of energy shortages"). 
conserving natural resources-provide FERC authority to consider a broader array of costs and benefits, including environmental consequences, as it seeks to maximize social welfare when approving or ordering changes to electricity market rules.

\section{Applying Cost-Benefit Analysis}

A full examination of the economic methods and practical tools available to FERC and RTOs in the development of cost-benefit analyses is beyond the scope of this Article. However, this Section discusses, at a high level, the categories of costs and benefits that FERC should consider when developing or evaluating cost-benefit analyses of RTO market rules. It also identifies some of the economic tools that can be used to estimate costs and benefits.

\section{Categories of Costs and Benefits}

The goal of an RTO's cost-benefit analysis should be to assess what effect a proposal has on social welfare. FERC should evaluate benefits and costs to "all beneficiaries, consumers, producers, and society at large, without regard to circumstances or location." 302 As a result, FERC should quantify and monetize at least the following categories of costs and benefits and incorporate them into a cost-benefit analysis. Consistent with Circular A-4, net benefits can be calculated by summing the net present value of each category of costs and benefits as compared to a baseline that extends the status quo into the future.303

\section{a. Efficiency Effects}

Market rule changes primarily affect the incentives for investment in and operation of electricity generation. These changes can lead to more or less efficient operation and investment that eliminates or increases deadweight loss, and improves or reduces the aggregate welfare of consumers and producers.304 Economists have developed tools to estimate these

302 RTO CBA REPORT, supra note 14 , at 6.

303 CIRCULAR A-4, supra note 2, at 15 (discussing development of a baseline); Id. at 3132 (describing the importance of discounting and the calculation of net present value). 304 See RTO CBA REPORT, supra note 14, at 15. 
benefits and costs, including benefits and costs produced by changing the efficiency of generation dispatch, changing the efficiency of unit commitment, changing the incentives to maximize the efficient operation and maintenance of individual generators, and reducing or increasing the need for generation and transmission investment.305

\section{b. Distribution of Costs and Benefits}

RTO market rules not only improve or detract from the efficiency of the wholesale markets, they can also substantially affect the distribution of costs and benefits between consumers and producers. Cost-benefit analyses of these rules should, when possible, separately characterize the costs and benefits of these important groups of market participants.

As Circular $A$-4 cautions, it is important for a cost-benefit analysis of market rules to distinguish between how a rule would change economic efficiency and how the rule would change the amount of money consumers pay producers for a service.306 The latter constitutes transfer payments that, while important for FERC to consider, are different than the change in aggregate social welfare. FERC has not always recognized this distinction when evaluating cost-benefit analyses. 307

\section{c. Administrative Costs}

RTO market rule changes can increase or decrease the cost of administering the RTO. Third-party cost-benefit studies often

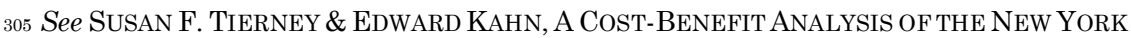
INDEPENDENT SYSTEM OPERATOR: THE INITIAL YEARS, 10-16 (2007) (discussing literature that estimates the different types of costs and benefits of RTO market rule changes). See generally RTO CBA REPORT, supra note14 (reviewing studies of the anticipated costs and benefits of RTOs).

306 CIRCULAR A-4, supra note 2, at 14, 38, 46.

307 In New England Power Pool ISO New England Inc., 111 FERC \ 61,064, at P 2 (Apr. 18, 2005), FERC considered an analysis that included two alternative measures of the benefits of the demand response program: (1) the benefits of reduced prices to consumers (called "transfer benefits"), and (2) the change in net social welfare produced by a more efficient allocation of supply and load (citing NEENAN ASSOCIATES, LLC, THE COSTS AND Benefits of Implementing a Day-Ahead Load Response Program (Feb. 1, 2005), attached to Compliance Filing of the New England Power Pool Participants Committee and ISO New England Inc., Docket No. ER04-1255-001 (Feb. 18, 2005) [hereinafter DALRP Compliance Filing]. ISO-NE used the transfer benefits in its filing with FERC. Id. at 8 . 
include changes in RTO budgets as an important cost category.308 These costs are easily determined because RTO's are required to submit an annual accounting of their costs to FERC.309

\section{d. Reliability (and Resilience)}

Because of network effects in the electric system, electric system reliability and resilience are public goods.310 As a result, the market will underprovide reliability and resilience and market rule changes can be designed to improve efficiency by enhancing reliability and resilience. When possible, a costbenefit analysis of a market rule should estimate the extent to which the rule would reduce the likelihood of grid outages (that is, would increase reliability or resilience). Consistent with Circular A-4, the value of avoided grid outages can be monetized based on the amount a consumer is willing to pay to avoid an outage.311 Economic measures of consumer willingness to pay to avoid outages - the VOLL-are available and can be incorporated into cost-benefit analyses. 312

\section{e. Environmental Costs and Benefits}

The costs and benefits of RTO market changes are not limited to costs and benefits that inure directly to market participants. The generation and sale of electricity produces substantial costs to the public that are not borne directly by producers or consumers of electricity. Most prominently, this includes environmental costs of electricity generation. By changing the incentives of market participants, RTO market rules can have a substantial effect on the magnitude of these external costs. For example, recent proposed market rules that would have compensated coal-fired generation for alleged resilience benefits 313 would increase the amount of greenhouse gases

308 See TIERNEY \& KAHN, supra note 305 , at 37.

30918 C.F.R. $\S 141.1($ b) (2018).

310 See Noll \& Unel, supra note 297, at 36-37 \& n.240 (defining public goods and explaining how reliability functions as a public good); BURCIN UNEL \& AVI ZEVIN, Towards Resilience: Defining Measuring and Monetizing Resilience in the ELECTRICITY SYSTEM 13 ( 2018).

311 CIRCUlar A-4, supra note 2, at 18-20.

312 See BURLINGAME \& WALTON, supra note 159, at 44-60.

313 See DOE NOPR, supra note 33, at 46,945. 
emitted by the electric system and cause billions of dollars in climate damages. 314 FERC should estimate the value of externalities generated by market rule changes into its costbenefit analyses of those changes. This information can help inform the Commission and the public regarding the consequences of the proposed changes to entities other than market participants.

\section{Economic Tools}

There are a number of economic tools available to FERC in order to estimate the costs and benefits of market rule changes and to monetize those costs and benefits to the greatest extent technically feasible.

\section{a. Electricity Market Modeling}

Several electricity market models are available, which would allow FERC to simulate how specific market rules will affect investment in and retirement of generation and transmission resources, electric system operational changes, and market prices. These models can be used to assess the efficiency effects and distributional consequences of market rules.

Capacity expansion models are used to simulate generation and transmission investment given assumptions about future energy prices, technology costs, and energy policies. 315 Production cost models can simulate hourly energy prices, unit generation, revenues and fuel consumption, energy market prices, external market transactions, transmission flows, losses, and congestion prices for a given set of market rules. These include proprietary models such as PROMOD, PROSYM, and GE-MAPS, which have been approved as valid analytical models by FERC,316 and have been used to conduct cost-benefit analyses

314 Daniel Shawhan \& Paul Picciano, Retirement and Funerals: The Emissions, MorTALity, AND COAL-Mine EMPLOYMENT EFFECTS OF A TWO-YEAR DELAY IN COAL AND Nuclear Power Plant Retirements, Resources for the Future, RFF WP18-18 (Jul. $5,2018)$.

315 Erin Boyd, U.S. DeP’t of Energy, Overview of Power Sector Modeling 9-11 (2016), https://www.energy.gov/sites/prod/files/2016/02/f29/EPSA_Power_Sector_ Modeling_020416.pdf [https://perma.cc/5BWW-FNYJ].

316 Midcontinent Indep. Sys. Operator, Inc., 145 FERC @ 61,248, 62,377 (Dec. 18, 2013)

(approving use of PROMOD); Entergy Servs., Inc., 116 FERC - 61,296, at 66 (2006) 
of RTO rules. 317 The consulting firm ICF International has developed a comprehensive computer simulation model of the electric system, the Integrated Planning Model ("IPM"). IPM is an optimization model that allows simulation of both grid operations and capacity expansion. IPM has been used by FERC to evaluate costs and benefits of particular RTO-related rulemakings, including FERC's economic analysis of Order 2000318 and the economic analysis supporting the Standard Market Design rulemaking. 319 Open-source models are also available, including the Energy Information Administration's National Energy Modeling System (NEMS), which has been used to conduct economic analysis of key FERC rules. 320

\section{b. Air Pollution Damage Modeling}

As outlined above, an important externality associated with electricity generation is the public health and environmental damage that results from the emission of air pollutants. The electricity market models discussed above can be used to simulate how market rule changes will result in the change in operation of different electric generating units. Some models, such as IPM and NEMS, incorporate air pollution emissions of modeled resources into the available model outputs. 321 Using these model outputs, the simulated change in the quantity of air pollution can then be monetized using publicly available modeling tools.

For conventional air pollutants, a number of modeling tools are available to translate a quantity of emissions of sulfur

\footnotetext{
(approving use of PROSYM); The New PJM Cos., 106 FERC \ 63,029, 65,314 (May 12, 2004) (approving use of GE-MAPS).

317 RTO CBA REPORT, supra note 14, at 27 (listing models for each RTO market study including, PROMOD and GE-MAPS).

318 FERC, Regional Transmission Organizations Rulemaking EnVironmental Assessment, Docket No. RM99-2-000 at 25-26 (1999).

319 RTO STUDY, supra note 209, at 28.

320 ENERgy Info. Admin., An ANAlysis of FERC's Final EnVIRONMEntal ImPaCt STATEMENT FOR ELECTRICITY OPEN ACCESS AND RECOVERY OF STRANDED COSTS (1996), https://www.eia.gov/analysis/requests/archive/1996/oiaf9603.pdf [https://perma.cc/26WQ-9R88].

${ }_{321}$ RTO STUDY, supra note 209, at 28; EnERgy InFo. AdMin., The NATiOnAl ENERgY MODELING SYSTEM: AN OVERVIEw 2009 at 43 (2009), https://www.eia.gov/outlooks/aeo/ nems/overview/pdf/0581(2009).pdf [https://perma.cc/VPR8-Y22L].
} 
dioxide, nitrous oxides, and particular matter into monetary estimates of health and agricultural damages.322

For greenhouse gases, the Social Cost of Carbon is a widely accepted tool developed by the Interagency Working Group on the Social Cost of Greenhouse Gases ("IWG") 323 to estimate the net-present value of climate damage caused by the emission of carbon dioxide. 324 The IWG's estimate has been repeatedly endorsed by government reviewers, courts, and experts including the National Academy of Sciences.325 And while the Trump Administration has disbanded the IWG and withdrawn the technical support documents, 326 the estimates produced by the IWG remain the best available estimates of the social cost of greenhouse gas emissions. 327

\section{c. Resilience Modeling}

RTOs are currently in the process of evaluating longer-term market rule changes to enhance the resilience of the generating system.328 Moreover, FERC may take action to address broader

322 See Jeffrey Shrader, Burcin Unel \& Avi Zevin, Inst. For Policy Integrity, VAluing Pollution Reductions: How to Monetize Greenhouse Gas AND LoCAL AiR Pollutant REDUCTIONS FROM Distributed ENERGY RESOURCES 22-24 (2018), https://policyintegrity.org/publications/detail/valuing-pollution-reductions [https://perma.cc/559Y-A7RZ].

323 The IWG, a collection of 13 federal agencies and White House offices, first developed the Social Cost of Carbon in 2010 and updated the estimate in 2013 and 2015. See NAT'L Research Council, Assessment of Approaches to Updating the Social Cost of CARbON: Phase 1 REPORT ON A NEAR-TERM UPdATE 6 (2016), https://www.nap.edu/catalog/21898/assessment-of-approaches-to-updating-the-socialcost-of-carbon [https://perma.cc/Q84S-3EUV].

324 InTERAGENCY Working GRP. ON Social Cost of Greenhouse Gases, TeChnical SUPPORT DOCUMENT (2016), https://obamawhitehouse.archives.gov/sites/default/ files/omb/inforeg/scc_tsd_final_clean_8_26_16.pdf [https://perma.cc/FSH9-FDUM]. 325 See U.S. GOV'T ACCOUNTABILITY OFF., GAO-14-663, REGUlatory IMPACT ANALYSis: Development OF SOCIAL COST OF CARBON Estimates 12-19 (2014), https://www.gao.gov/products/GAO-14-663 [https://perma.cc/23TH-Y7MF]; Zero Zone, Inc. v. Dep’t of Energy, 832 F.3d 654, 677-79 (7th Cir. 2016); NAT'L RESEARCH COUNCIL, Valuing Climate Damages: Updating Estimation of the Social Cost of CaRbon Dioxide 3 (2017); NAT'L RESEARCH COUNCIL, ASSESSMENT OF APPROACHES TO UPDATING the Social Cost of Carbon: Phase 1 Report on a Near-Term Update 6 (2016). 326 Exec. Order No. 13,783 § 5, 82 Fed. Reg. 16,093, 16,095-96 (Mar. 28, 2017). 327 Richard L. Revesz et al., Best Cost Estimate of Greenhouse Gases, 357 SCIENCE 655, 655 (2017).

328 See PJM, Fuel Security: ANALYZing Fuel Supply Resilience in the PJM REgion 7 (2018), https://www.pjm.com/-/media/committees-groups/committees/mrc/20181101fuel-security/20181101-pjm-fuel-security-summary.ashx [https://perma.cc/XB5B-6CYS] 
resilience concerns.329 To the extent an RTO or FERC acts to enhance system resilience it should use quantitative tools in order to estimate the costs and benefits of market rule changes aimed at enhancing resilience. 330 Probabilistic models of extreme events, combined with the production cost and capacity expansion models outlined above can be used to estimate the extent to which resilience focused market rule changes will reduce the expected number of hours of customer outages. The economic value of reduced outages can then be monetized using the Value of Lost Load or other metrics. DOE is currently developing an electric system model that will be able to assist in analyzing the expected reliability and resilience consequences of market rule changes, including for the purpose of cost-benefit analysis. 331

\section{E. Additional Examples of Cost-Benefit Analysis in Electric System Regulation}

This section has explored the potential for cost-benefit analysis to inform one particularly significant area of FERC responsibility over the electric sector that is relevant to the energy transition: RTO market rules. However, this is not the only area of FERC responsibility over the bulk electric system that would benefit from a more systematic, transparent, and holistic approach to decision making. For the reasons explored in Part II, cost-benefit analysis would also be a useful tool for other significant regulatory actions relevant to the transition of the electric system, including industry-wide rulemakings establishing requirements, 332 requirements to identify and

\footnotetext{
(describing "next steps" including the initiation of a stakeholder process to develop market rule changes); FERC, Motion for Extension of Time of ISO New England Inc. at 3-5, Docket No. EL18-182-000 (Jan. 18, 2019) (describing efforts to develop market rule changes to address resilience to fuel disruption).

329 See Gavin Bade, Glick Predicts Return to Resilience Debate as McNamee Prepares to Take FERC Seat, UTIL. DIVE (Dec. 11, 2018), https://www.utilitydive.com/news/glickpredicts-return-to-resilience-debate-as-mcnamee-prepares-to-take-ferc/544042/ [https://perma.cc/J3HT-QHEL].

330 See UNEL \& ZEVIN, supra note 310, at 13-20 (describing a cost-benefit analysis framework for assessing resilience interventions).

331 See U.S. DeP't of Energy, North American Resilience Model (2019), https://www.energy.gov/sites/prod/files/2019/07/f65/NAERM_Report_public_version_07 2219_508.pdf [https://perma.cc/7PUL-39KB].

332 Glick \& Christiansen, supra note 19, at 22-23.
} 
approve regional and interregional transmission lines within and outside of RTO markets,333 or implement the Public Utility Regulatory Policies Act of 1978 to facilitate deployment of small and renewable energy facilities. 334 Two additional types of FERC decisions are worth discussing briefly: the establishment of minimum reliability standards and the establishment of incentives for the construction of certain types of interstate electric transmission.

Recently there has been substantial public attention on whether the energy system transition will facilitate or hinder electric reliability and resilience.335 Concerns about reliability may continue in the face of increasing extreme weather events due to climate change.336 Cost-benefit analysis can provide a neutral framework for evaluating whether certain improvements to electric reliability are warranted.

In 2005, Congress provided FERC with additional authority to manage the reliability of the bulk power system.337 Under this authority, Congress directed FERC to name an electric reliability organization ("ERO") that would be responsible for developing mandatory standards for transmission, generation, and independent grid operators. 338 FERC may approve any proposed standards developed by the ERO that are "just, reasonable, not unduly discriminatory or preferential, and in the public interest." 339 In 2006, FERC chose the North American Electric Reliability Corporation as the ERO and issued regulations establishing a process for the development and

\footnotetext{
333 See Glick \& Christiansen, supra note 19, at 37-38 (discussing importance of transmission planning to energy system transition and addressing climate change); see AARON BLOOM, NAT'L RENEWABLE ENERGY LAB., INTERCONNECTION SEAMS STUDY 10103 (2019), https://cleanenergygrid.org/wp-content/uploads/2018/08/NREL-seamstransgridx-2018.pdf [https://perma.cc/K68A-A366] (finding substantial benefits to transmission expansion that connects Eastern and Western interconnections). 334 See Glick \& Christiansen, supra note 19, at 38-39.

335 See, e.g., Grid Resiliency Pricing, 82 Fed. Reg. 46,940 (proposed Oct. 10, 2017) (to be codified at 18 C.F.R. pt. 35); Calpine Corp. v. PJM Interconnection, Inc., 163 FERC $₫$ 61,236 (June 29, 2018).

336 See Justin Gundlach \& Romany Webb, Sabin Ctr. for Climate Change LaW, Climate Change Impacts on the Bulk Power System: Assessing Vulnerabilities AND PLANNING FOR RESILIENCE iii-ii (2018).

33716 U.S.C. $\$ 824$ (2018).

$338 I d$. at $\S \S 8240(\mathrm{c})$, (d).

$339 I d$. at $\S 824 \mathrm{o}(\mathrm{d})(2)$.
} 
approval of new reliability standards.340 FERC rejected the use of cost-benefit analysis as the appropriate decision making criterion for new reliability standards.341

FERC should reconsider that approach. Reliability standards necessarily impose costs on electric market participants (and ultimately consumers) by requiring capital investments, operational changes, and other actions. These changes are intended to produce benefits in the form of continued operation of the system in times of high stress. Cost-benefit analysis can provide a useful framework for transparently balancing these factors and associated costs. Because FERC's statutory authority over reliability standards uses language similar to what FERC has relied on to regulate RTOs-standards must be "just and reasonable" and "in the public interest"-FERC's authority to use cost-benefit analysis rests on the same legal foundation as discussed above.

Another area of FERC responsibility that would benefit from the use of cost-benefit analysis is FERC's award of incentives to certain transmission projects. As demand for renewable resources increases-due to cost declines, state climate policies, and consumer interest-so too will the need to build additional transmission. Unlike for wholesale electricity sales, FERC's approach to transmission regulation continues to primarily rely on traditional cost-of-service ratemaking principles. The rate charged for transmission service would be based on the costs of providing that service plus a return on equity. However, in 2005 , concerned that this approach was not yielding sufficient transmission development in the face of a changing electricity system, Congress adopted Section 219 of the FPA, which directs FERC to provide transmission developers with financial incentives such as additional ROE for projects that meet certain public policy objectives. 342 Congress required transmission incentives be used in certain circumstances, such as for

340 N. Am, Elec. Reliability Corp., 116 FERC \ 61,062 (July 20, 2006); Rules Concerning Certification of the Electric Reliability Organization; and Procedures for the Establishment, Approval and Enforcement of Electric Reliability Standards, 18 C.F.R. $\S$ 39 (2006).

${ }_{341}$ N. Am. Elec. Reliability, 116 FERC $\uparrow$ 61,062 ("EPAct 2005 does not mandate a caseby-case cost-benefit analysis and we are not prepared to mandate that.").

34216 U.S.C. $\S 824 \mathrm{~s}$. 
transmission owners that join an RTO,343 but left it to FERC to determine what other types of transmission projects warranted additional compensation and how much that additional compensation should be. In 2006, FERC issued Order 679, which established its incentive policy.344 FERC rejected the use of cost-benefit analysis as a tool to determine when a transmission project should be provided incentives. 345 Recently, Commissioners have expressed concern that the existing policy has functioned as a giveaway that has overcompensated some transmission projects that may have been developed anyway, without sufficiently incentivizing the development of beneficial new projects.346 As a result, FERC is currently reevaluating its transmission incentive policy. 347 FERC should take that opportunity to revise the process for evaluating potential transmission incentives. It should clarify that it will identify and, where possible, quantify the benefits and costs of additional proposed incentives, that it will balance those costs and benefits, and only adopt incentives where the benefits exceed the costs. In that context, cost-benefit analysis can be useful both in evaluating which categories of projects are deserving of incentives and as a decision making criteria in its evaluation of specific transmission incentive applications from developers. Section 219 provides sufficient authority for FERC to use costbenefit analysis, including a broad consideration of costs and benefits, when evaluating and choosing among potential transmission incentives. FERC is directed to incentivize facilities that "promote reliable and economically efficient transmission and generation of electricity." 348 Improvement of efficiency is one of the fundamental principles of cost-benefit analysis; the direction to improve the economic efficiency of the transmission system leaves a clear opening for balancing costs and benefits, including those that accrue to entities other than electric system producers and consumers.

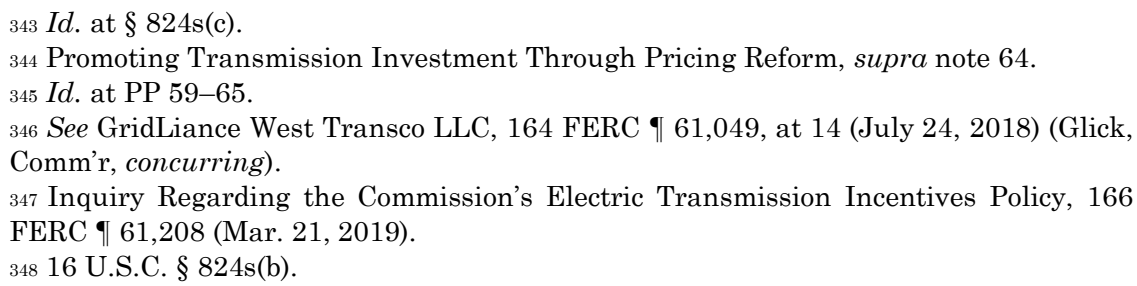




\section{NATURAL GAS PIPELINE CERTIFICATE APPROVALS}

Part IV evaluates the prospect for cost-benefit analysis to serve as a useful tool as FERC attempts to balance competing interests and maximize social welfare when evaluating the expected increase in new applications to construct and operate interstate natural gas pipelines. 349

\section{A. FERC's Role and Current Approach}

This section provides an overview of FERC's role overseeing the development of new natural gas infrastructure such as pipelines, storage facilities, and export terminals. It then discusses FERC's current approach to evaluating applications for new and expanded and evaluates a recent FERC decision not to employ cost-benefit analysis.

\section{FERC's Role Overseeing Construction and Operation of} Natural Gas Pipelines

Under the NGA, Congress gave the FPC (and, subsequently, FERC) the responsibility for permitting the construction and operation of interstate natural gas facilities. 350 FERC's permitting responsibility extends to interstate pipelines and associated facilities such as compressor stations, as well as natural gas storage facilities, and liquified natural gas import and export terminals.351 As FERC has explained, "[i]t is well established law that the NGA preempts state and local agencies from regulating the construction and operation of interstate pipeline facilities or the siting of those facilities." 352 As a result, FERC regulation serves as the primary mechanism for ensuring that pipelines will be built in the public interest.

${ }_{349}$ See Christopher E. Smith, Near-Term Pipeline Plans Nearly Double, Future Slows, OIL \& GAS J. (Feb. 5, 2018), https://www.ogj.com/articles/print/volume-116/issue2/special-report-worldwide-pipeline-construction/near-term-pipeline-plans-nearlydouble-future-slows.html [https://perma.cc/R4XS-ZMN3].

35015 U.S.C. $\S 717 f$ (2018). For a history of natural gas infrastructure development and regulation see Klass \& Meinhardt, supra note 28, at 989-1015.

35115 U.S.C. $§ 717 b$ (2018 (giving FERC authority for the permitting of facilities used in the export or import of natural gas).

352 Millennium Pipeline Company, LLC, 141 FERC 9 61,198, at P 68 (2012) (citing Nat'l Fuel Gas Supply Corp. v. Pub. Serv. Comm'n of New York, 894 F.2d 571 (2d Cir. 1990)). 
FERC exercises its responsibility through the issuance of "certificates of public convenience and necessity." 353 Such certificates are required before a company can construct, extend, acquire, or operate any facilities for the interstate transportation of natural gas.354 A pipeline developer submits a certificate application to FERC pursuant to regulations outlining the application process. 355 FERC's role is to then determine whether the proposed project "is or will be required by the present or future public convenience and necessity." 356 When evaluating a proposed project, FERC can accept the application, reject the application, or accept the application with "such reasonable terms and conditions as the public convenience and necessity may require." 357

\section{Cost-Benefit Analysis in a Supporting Rule}

FERC's approach to evaluating proposed natural gas projects has changed over time in response to changes in the industry.358 The most recent significant revision to FERC's approach came in 1999, with the issuance of what FERC calls the "1999 Policy Statement," 359 spurred by changes in the natural gas industry.360 FERC instituted a process of deregulation and restructuring that led to a substantial increase in the supply of and demand for natural gas, and a substantial buildout of natural gas infrastructure.361 This resulted in growing public

35315 U.S.C. $\S 717 f(c)(2018) ; 18$ C.F.R. pt. 157.

35415 U.S.C. $\$ 717 f(c)(2018)$.

355 Id. at $\S 717 \mathrm{f}(\mathrm{d})$.

356 Id. at $\S 717 f(\mathrm{e})$.

$357 I d$. at $\S 717 \mathrm{f}(\mathrm{e})$. FERC may grant conditional certificates that require compliance with other obligations such as Clean Air Act and Clean Water Act permitting. See Del. Riverkeeper Network v. Fed. Energy Regulatory Comm'n, 857 F.3d 388, 399 (D.C. Cir. 2017) (upholding FERC certificate conditioned on Clean Water Act compliance); Myersville Citizens for a Rural Cmty., Inc. v. FERC, 783 F.3d 1301, 1320-21 (D.C. Cir. 2015) (upholding FERC certificate conditioned on Clean Air Act compliance).

358 See Robert Christin, Paul Korman \& Michael Pincus, Considering the Public Convenience and Necessity in Pipeline Certificate Cases Under the Natural Gas Act, 38 ENERGY L.J. 115, 121-31 (2017) (recounting the evolution of FERC's interpretation of "public convenience and necessity" as the natural gas industry evolved).

3591999 Policy Statement, supra note 16.

360 TIERNEY, supra note 28, at 7, 14-36 ("FERC had been exploring issues related to thencurrent policies on certification and pricing of pipeline projects in light of changes that had taken place in the industry leading up to the late 1990 s").

${ }_{361}$ Christin et al., supra note 358, at 123-25 (describing industry changes). 
concern that FERC's approach to pipeline project approvalswhich primarily turned on whether a proposed project had contracts or other expressions of interest from customers-was serving private developers instead of the public interest. 362 FERC issued its 1999 Policy Statement to help FERC balance "market demand against potential adverse environmental impacts and private property rights in weighing whether a project is required by the public convenience and necessity." 363 FERC's intention, therefore, appeared to be to use tools that were becoming more entrenched in the cost-benefit state to make better informed decisions. This is reflected in FERC's goal of "provid[ing] appropriate incentives for the optimal level of [pipeline] construction and efficient customer choices." 364

The 1999 Policy Statement sought to accomplish these goals through a three-step process. First, in order to receive a certificate, an existing pipeline must meet a "threshold requirement" that it will not rely on cross-subsidization from existing customers.365 Second, FERC "balance[es] the evidence of public benefits to be achieved against the residual adverse effects." 366 FERC will approve a project "only when the benefits outweigh the adverse effects on economic interests." 367 FERC characterizes this step as the "economic test" or "balancing test." 368 The Policy Statement describes a number of potential "indicators of public benefit" that FERC will consider when evaluating a project. This includes "meeting unserved demand, eliminating bottlenecks, access to new supplies, lower costs to consumers, providing new interconnects that improve the interstate grid, providing competitive alternatives, increasing electric reliability, or advancing clean air objectives." 369 The Policy Statement explains that FERC will evaluate the adverse consequences of a pipeline project on at least the following interests: "interests of existing customers of the pipeline applicant," interests of existing pipelines that already serve the

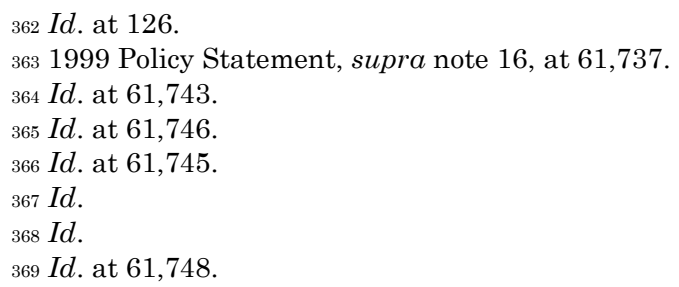


market," "and "interests of landowners and surrounding communities." 370 Third, for projects that pass the economic test, FERC moves to an environmental review. 371 This review involves consideration of the environmental consequences of the pipeline that are described in an EIS or EA prepared pursuant to the requirements of NEPA. 372 In practice, in order to facilitate a more expeditious FERC decision on a certificate application, almost all applicants take advantage of a pre-filing procedure that allows FERC to begin its NEPA review before or concurrent with its economic test.373 Nonetheless, adverse environmental consequences of a project do not factor into the balancing test.374 FERC has not clearly delineated a methodology for incorporating the consequences described in its NEPA review into its decision of whether the project is in the public interest in light of the benefits and adverse consequences it evaluates in the economic test.

At a time of transition in the natural gas industry, FERC issued a Policy Statement that uses the language of cost benefit balancing, and suggested it intended to rely on such balancing when evaluating new projects. However, as the next section describes, in practice, FERC has not adopted cost benefit analysis.

\section{FERC's Constrained Approach to Approving Natural Gas Infrastructure}

As the Policy Statement has been implemented over the last twenty years, FERC does not actually apply cost-benefit analysis as its decision making framework.375 First, FERC's approach is not generally quantitative. Recently, FERC has been explicit, describing its economic test as "qualitative," and claiming it does "not monetize benefits or monetize adverse economic effects.” 376

370 Id. at $61,747-48$.

371 Id. at 61,745 .

37242 U.S.C. $\S 4321$ et seq.

373 See Christin et al., supra note 358, at 131.

374 Midwestern Gas Transmission Co., 116 FERC - 61,182, 61,781 (Aug. 25, 2006) (the

"economic test ... precedes an environmental analysis. The Commission ... thus did not err by failing to balance project need and benefits against adverse environmental impacts").

375 SMP Project Remand Order, supra note 62, at PP 39-44.

376 Id. at $\mathrm{P} 43$. 
FERC's "weighing" of costs and benefits is, therefore, not objective but subjective. And, orders approving pipeline certificates do not typically explain why FERC believes a given level of benefits are sufficient to justify the types of adverse impacts that will result from a project. 377

The costs and benefits that FERC considers in practice are also narrower than would be used in a rigorous, sophisticated cost-benefit analysis. In its 1999 Policy Statement, FERC committed to moving away from its prior approach of looking almost exclusively at whether a project developer had signed contracts as a sufficient demonstration of public need for the pipeline.378 However, since 1999, FERC has characterized the Policy Statement as permitting but not requiring FERC to look beyond the existence of contracts between developers and customers, 379 and FERC has exercised its discretion to rely primarily or exclusively on contracts. 380 FERC's reliance primarily on contracts has garnered substantial criticism among

377 Compare Spire STL Pipeline LLC, 164 FERC @ 61,085, at P 123 (Aug. 3, 2018) [hereafter "Spire STL Certificate Order"] (providing cursory and conclusory statement regarding why benefits outweigh harms) with id. at 61,527-31 (Glick, Comm'r, dissenting) (engaging in a more thorough weighing of costs and benefits).

3781999 Policy Statement, supra note 16, at 61,744 (the "amount of capacity under contract ... is not a sufficient indicator by itself" of need).

${ }_{379}$ Spire STL Certificate Order, supra note 377, at P 72 (emphasis added) (characterizing contracts to be "substantial and sufficient evidence of need").

380 Nat'l Fuel Gas Supply Corp., 158 FERC \ 61,145, 61,955 (Feb. 3, 2017) (Bay, Comm'r, separate statement) ("The certificate policy statement, which was issued in 1999, lists a litany of factors for the Commission to consider in evaluating need. Yet, in practice, the Commission has largely relied on the extent to which potential shippers have signed precedent agreements for capacity on the proposed pipeline"); Mountain Valley Pipeline, LLC, 161 FERC - 61,043, at PP 38-42 (2017) (relying on precedent agreements to support a project notwithstanding market studies presented by stakeholders that question whether there is sufficient demand for additional transportation service); Spire STL Certificate Order, supra note 377, at 61,528 (Glick, Comm'r, dissenting) (explaining that FERC relied on a single precedent agreement despite evidence that the pipeline would not increase access to gas in the region); PennEast Pipeline Co., 162 FERC 61,053, 2018 WL 487260, at *71 \& n.242 (2018) (Glick, Comm'r, dissenting) (FERC "relies exclusively on the existence of precedent agreements with shippers to conclude that the PennEast Project is needed"). 
the public. 381 It has also raised litigation risk for project approvals.382

When evaluating costs, the Policy Statement claims to consider "all the affected interests" including "the general societal interests." 383 But FERC does not include the environmental harms it has cataloged as part of the NEPA process in its balancing test.384 Therefore, it is not clear what level or type of environmental consequences would tip the scales and lead a project to be rejected. In fact, FERC has never rejected a certificate on the basis of the environmental harm that will be caused by the pipeline project.385

In short, while FERC's description of its decision-making process for evaluating pipeline certificates uses the language of costs and benefits, FERC has not actually embraced cost-benefit analysis in practice.

\section{B. FERC Should Adopt an Expanded Cost Benefit Requirement}

We are again at a time of transition in the natural gas sector. Advances in technology-primarily hydraulic fracturing and horizontal drilling-have enabled a significant increase in the

\footnotetext{
381 Comments of Public Interest Organizations at 23-41, Certification of New Natural Gas Facilities, 163 FERC 9 61,138 http://friendsofnelson.com/wp-content/uploads/ 2018/07/Comments-of-the-Public-Interest-Organizations-FINAL.pdf

[https://perma.cc/AXA7-WT7G] (explaining that FERC's reliance on contracts between developers and customers is inconsistent with the NGA and the 1999 Policy Statement; increases the risk of stranded assets; and incentivizes overbuilding).

382 See Joint Brief of Petitioners N.J. Dep't of Envtl. Prot., Del. and Raritan Canal Comm'n, and N.J. Div. of the Rate Counsel at 15-21, Del. River Keeper Network v. FERC, (No. 18-1128) (filed Dec. 21, 2018).

3831999 Policy Statement, supra note 16, at 61,747.

384 See Romany M. WebB, Sabin Ctr. for Climate Change, Climate Change, FERC, and Natural Gas Pipelines: The Legal Basis For Considering Greenhouse Gas EMissions UNDER SECTION 7 OF THE NATURAL GAS ACT 25-27 (2019), http://columbiaclimatelaw.com/files/2019/06/Webb-2019-06-Climate-Change-FERCand-Natural-Gas-Pipelines.pdf [https://perma.cc/4UGZ-2AKQ].

385 FERC has rejected only two natural gas infrastructure certificates, neither of which were denied on the basis of the project's environmental harm. See Jordan Cove Energy Project, L.P., 154 FERC 9 61,190, at PP 39, 47 (Mar. 11, 2016) (finding limited public need and harm to landowners, without considering environmental harms); Turtle Bayou Gas Storage Co., 135 FERC \ 61,233, at PP 33-35 (2011) (rejecting project because of limited benefit compared to adverse impact on a landowner, without reaching environmental consequences).
} 
domestic production of natural gas at lower costs. 386 This technology has unlocked natural gas supplies in geologic shale formations that are often located in different areas of the U.S. from where natural gas extraction has been dominant.387 At the same time, as a result of advances in electric generation technology and low-cost gas supplies, the electric system has become a substantial new user of natural gas.388 As a result, the changing economics of natural gas extraction and consumption have led to a significant increase in demand for new natural gas infrastructure to connect new supplies to new and existing markets.389 FERC is under substantial pressure from politicians and industry to approve the construction of new natural gas infrastructure; 390 while at the same time FERC is under substantial pressure from states, community groups, and environmental organizations to proceed cautiously in order to minimize the disruption to landowners, communities, and the environment-in particular climate change. 391 Given this transition, and FERC's competing objectives in helping to manage it, now is an apt time to fulfill the promise of the 1999 Policy Statement and fully embrace cost-benefit analysis as it evaluates natural gas infrastructure.

Recently, when faced with a request that it monetize the consequences of greenhouse gas emissions, FERC put forth a series of explanations for why it has not embraced cost-benefit

386 Klass \& Meinhardt, supra note 28, at 999-1000 (discussing the growth of U.S. natural gas production caused by technological changes).

387 Policy Statement NOI, supra note 28, at P 21 (describing changes in natural gas production location, including substantial increases in volume in Pennsylvania, West Virginia, Ohio, and New York and new development in North Dakota).

388 TIERNEY, supra note 28, at 23-24 (showing increasing usage of gas in the electric power sector).

389 Policy Statement NOI, supra note 28, at P 21 (describing the increase in pipeline certificate applications since 2010).

390 Paul W. Parfomak, Cong. Research Serv., R45239, Interstate Natural Gas PIPELINe Siting: FERC POLICY AND Issues FOR CONGREss 14, 17-19 (2018), https://crsreports.congress.gov/product/pdf/R/R45239/5 [https://perma.cc/R53S-26NU] (describing executive orders and proposed legislation intended to streamline and speed FERC's pipeline certificate review process); see, e.g., Tom Johnson, PennEast Wants Fast-Track Approval from FERC for \$1B Pipeline, NJSPOTLIGHT (Aug. 14, 2017) https://www.njspotlight.com/2017/08/17-08-13-penneast-wants-fast-track-approvalfrom-ferc-for-its-1b-pipeline/ [https://perma.cc/MYB4-7RUY].

391 TIERNEY, supra note 28, at 29-30 (describing increased opposition to natural gas pipelines from a diversity of stakeholders). 
analysis.392 However, none of FERC's arguments are ultimately persuasive. 393

First, FERC pointed to regulations from the Council on Environmental Quality ("CEQ") that do not require use of costbenefit analysis for NEPA reviews.394 However, that CEQ does not require FERC to use cost-benefit analysis is not itself a justification for FERC failing to use the tool for all of the reasons explored in Part II. CEQ regulations govern agencies' responsibilities for complying with NEPA.395 This justification, therefore, does not implicate FERC's decision regarding how to evaluate whether a project is required for the public convenience and necessity under the NGA. Agencies regularly monetize costs and benefits in order to make decisions consistent with their statutory responsibilities separate from the NEPA analysis that is conducted pursuant to CEQ regulations.396

In fact, FERC has previously used a limited form of costbenefit analysis to make certain decisions under the NGA. In 1994, FERC evaluated an application for abandonment of a certificated liquified natural gas facility through a sale and leaseback proposal, pursuant to NGA Section 7(b).397 In order to facilitate its evaluation of whether the "present or future public convenience or necessity permit such abandonment," 398 FERC

392 SMP Project Remand Order, supra note 62, at PP 39-44. While the SMP Project Remand Order presents FERC's first detailed justification for its decision not use costbenefit analysis, it is not FERC's first mention of the prospect of using cost-benefit analysis in the certificate process. In a 2003 final EIS, FERC explained that its review of socioeconomic impacts as part of its NEPA review does not require a "rigorous costbenefit analysis." Fed. Energy Regulatory Comm'n, Final Environmental Impact Statement for the Greenbrier Pipeline Project, M-88, (2003).

393 FERC has also repeated the justifications provided in Florida Southeast Connection in a number of subsequent decisions regarding pipeline certificates. See, e.g., Millennium Pipeline Company, LLC, 164 FERC \ 61,039, at PP 25-28 (July 19, 2018); DTE Midstream Appalachia, LLC, 162 FERC \ 61,238, at P 80 (Mar. 15, 2018).

394 SMP Project Remand Order, supra note 62, at P 40.

39540 C.F.R. $\S 1502.23$ (2012).

396 See California v. Watt, 712 F.2d 584 (D.C. Cir. 1983) (upholding Department of Interior use of cost-benefit analysis when managing offshore oil and gas leasing); The Safer Affordable Fuel-Efficient (SAFE) Vehicles Rule for Model Years 2021-2026 Passenger Cars and Light Trucks, 83 Fed. Reg. 42,986 (proposed Aug. 24, 2018) (using cost-benefit analysis to evaluate proposed fuel economy standards for passenger vehicles while conducting a separate environmental impact statement to comply with NEPA). 397 Northern Natural Gas Company and Continental Gas Storage, 66 FERC @ 61,092 (1994) [hereafter Northern Natural Gas Order].

39815 U.S.C. $\S 717 f(b)(2012)$. 
"developed cost-benefit analyses" of the applicant's proposed rate treatment and the traditional cost-of-service model. 399 Relying on those analyses, FERC found that the proposal would result in substantial operation and maintenance cost increases without commensurate benefits, as compared to the alternative, and so rejected the proposal.400

Second, FERC argued that it does not use cost-benefit analysis "because siting infrastructure necessarily involves making qualitative judgments between different resources as to which there is no agreed-upon quantitative value." 401 But, the need to make qualitative judgments is true for most agencies that regularly perform cost-benefit analyses. Even where benefits cannot be quantified, they can still be taken into account. Moreover, most of the relevant costs and benefits for evaluating whether a project is required for the public convenience and necessity - the value of additional natural gas, the reduction in consumer prices, the cost to construct a pipeline, the direct emission of greenhouse gases - can be readily monetized using tools available to FERC. 402 In fact, FERC uses cost-benefit analysis when making infrastructure approval decisions in the context of hydroelectric dam license applications, 403 and has not explained why monetization would be appropriate for hydroelectric infrastructure projects but not natural gas projects.

Third, FERC reasoned that "Commission staff lacked quantified information about all of the costs and benefits of the project." 404 As the D.C. Circuit recently concluded, FERC can require applicants to provide information needed to more fully evaluate the consequences of a project.405 Even if there is not sufficient information for all costs and benefits to be monetized, that does not foreclose the use of cost-benefit analysis, and the use of cost-benefit analysis does not foreclose qualitative

399 Northern Natural Gas Order, supra note 397, at 61,134.

$400 I d$. at 61,135 . In this proceeding, FERC primarily looked at the private costs and benefits as between the LNG terminal owner and existing customers and so is not as comprehensive as the analysis that FERC should conduct when evaluating pipeline certificate applications.

401 SMP Project Remand Order, supra note 62, at P 40.

402 See Part IV(b), infra.

403 See U.S. FISH AND WILDLIFE SERVICE, supra note 67, and accompanying text.

404 SMP Project Remand Order, supra note 62, at P 40.

405 Birckhead v. FERC, 925 F.3d 510, 520 (D.C. Cir. 2019). 
consideration of costs and benefits that cannot be monetized. For those costs and benefits for which monetization is possible, they can be directly included in a cost-benefit analysis. For those that cannot be monetized, FERC can describe the consequences qualitatively. When quantification is not possible, FERC can present the issue qualitatively.406 FERC can then exercise its expert judgment-potentially with the help of break-even analysis - to evaluate the extent to which unmonetized costs and benefits are significant enough to change its decision regarding whether a project is in the public interest.407 Supplementing cost-benefit analysis with qualitative assessments is common practice, 408 and can allow FERC to conduct a more holistic evaluation of a pipeline certificate. This type of hybrid analysis is consistent with Circular A-4.409

Fourth, FERC argued that cost-benefit analysis would be "misleading" because it would "necessarily be based on multiple assumptions." 410 However, agencies, including executive agencies that conduct cost-benefit analyses as required by Executive Order 12,866, regularly are required to make assumptions regarding uncertain consequences such as future market conditions and other inputs when analyzing their actions.411 The use of assumptions, so long as they are disclosed and supported by evidence, does not make an analysis misleading.412 Circular $A$ - 4 recommends the use of sensitivity

406 CirCUlar A-4, supra note 2, at 27. While CirCUlAR A-4 was issued in 2003 to guide agency analyses that accompany proposed and final regulations, the principles are applicable to review of individual projects. See Jayni Hein, Federal Lands and Fossil Fuels: Maximizing Social Welfare in Federal Energy Leasing, 42 HARV. ENVTL. L. REV. 1, 48-49 (2018).

${ }_{407}$ CIRCULAR A-4, supra note 2, at 2 (discussing break-even analysis).

408 See, e.g., Nat. Res. Def. Council v. Hodel, 865 F.2d 288, 306-08 (D.C. Cir. 1988) (upholding the Department of Interior's use of a combination of cost-benefit analysis and qualitative factors to determine which areas to include in an offshore leasing program). 409 CIRCULAR A-4, supra note 2, at 27 ("If monetization is impossible, explain why and present all available quantitative information. ... You should describe the timing and likelihood of such effects and avoid double-counting of benefits when estimates of monetized and physical effects are mixed in the same analysis.").

410 SMP Project Remand Order, supra note 62, at P 41.

${ }_{411}$ Sierra Club v. U.S. Dep't of Energy, 867 F.3d 189, 198 (D.C. Cir. 2017) ("an agency must engage in 'reasonable forecasting and speculation"' as part of its evaluation of environmental consequences).

${ }_{412}$ See CIRCULAR A-4, supra note 2, at 3 ("For transparency's sake, you should state in your report what assumptions were used, such as the time horizon for the analysis and the discount rates applied to future benefits and costs"). 
analysis, which "examine[s] how the results of [an agency's] analysis vary with plausible changes in assumptions, choices of input data, and alternative analytical approaches." 413 In fact, the countervailing assumption FERC makes by not quantifying and monetizing climate damages - that there is no reasonably foreseeable consequence-is itself misleading. For example, the United States Court of Appeals for the Ninth Circuit found an agency's failure to monetize the climate damages of vehicle emission standards "put a thumb on the scale" of its decision because, while there were uncertainties in the calculation of climate damages, the value was clearly not zero, yet by failing to provide any estimate, the agency treated the decision as if it would result in no climate damages.414 FERC's decision not to monetize climate damages is similarly misleading because it leads the Commission to disclaim consideration of the costs of upstream and downstream greenhouse gas emissions. 415

Not all Commissioners agreed with FERC's rejection of costbenefit analysis as a useful tool for evaluating pipeline certificate applications. In a partial dissent to the rehearing order, Commissioner Cheryl LaFleur acknowledged that the Commission's historic practice has been to not use a monetized cost-benefit analysis to evaluate pipeline projects. 416 But she did not embrace the Commission's justification for that failure. Rather, she attributed the failure to use cost-benefit analysis to the fact that "to date, we have not sought to develop the record with evidence that would [sic] that support this type of costbenefit approach to our pipeline reviews." 417 Commissioner LaFleur advocated for a more comprehensive evaluation of monetized costs and benefits in the certificate process.418 She

${ }_{413}$ CIRCULAR A-4, supra note 2 , at $41 ; i d$. at 3 ("It is usually necessary to provide a sensitivity analysis to reveal whether, and to what extent, the results of the analysis are sensitive to plausible changes in the main assumptions and numeric inputs").

${ }_{414}$ Ctr. for Biological Diversity v. Nat'l Highway Traffic Safety Admin., 538 F.3d 1172, 1198-1200 (9th Cir. 2008).

415 Gulf LNG, supra note 86, at P 4 (Glick, Comm'r, dissenting).

416 SMP Project Remand Order, supra note 62, at *17 (2018 WL 1364645) (LaFleur, Comm'r, dissenting in part).

${ }_{417} I d$.

$418 I d$. at *18 ("I believe that the best way to address climate change and the Social Cost of Carbon in pipeline dockets would be for the Commission to develop a more complete record on costs and benefits of the proposed project, including more information on the need for a project, the likely end-uses of the transported gas, and the alternatives."). 
reasoned that "increased openness" facilitated by a more transparent consideration of costs and benefits will "enhance public confidence in the Commission's natural gas pipeline certification decision-making process." 419

\section{Statutory Authority}

FERC would be on firm legal ground if it adopted cost-benefit analysis as a framework for evaluating pipeline certificate applications.

1. Cost-Benefit Analysis and the Public Convenience and Necessity Standard

FERC's task under Section 7 of the NGA is to determine if an interstate natural gas facility is, "or will be[,] required by the present or future public convenience and necessity." ${ }_{420}$ The NGA does not define "public convenience and necessity." However, by adopting that standard in 1938, Congress drew on a long history of its use in state public utility regulation.421 In a 1979 article, William K. Jones explored the history of the certificate of public convenience and necessity as a means of regulating public service companies.422 Jones found five longstanding rationales for the requirement that a company receive a certificate that informed states' decisions for when to issue such certificates. One of the key rationales that Jones identified was "the protection of the community against social costs." 423 According to Jones, states used certificate authority to limit the "divergence between social costs and benefits, on the one hand, and entrepreneurial costs and benefits, on the other, [which] could lead to entrepreneurial decisions at variance with socially optimal consequences." 424 A "frequently cited" social cost was environmental damage. 425

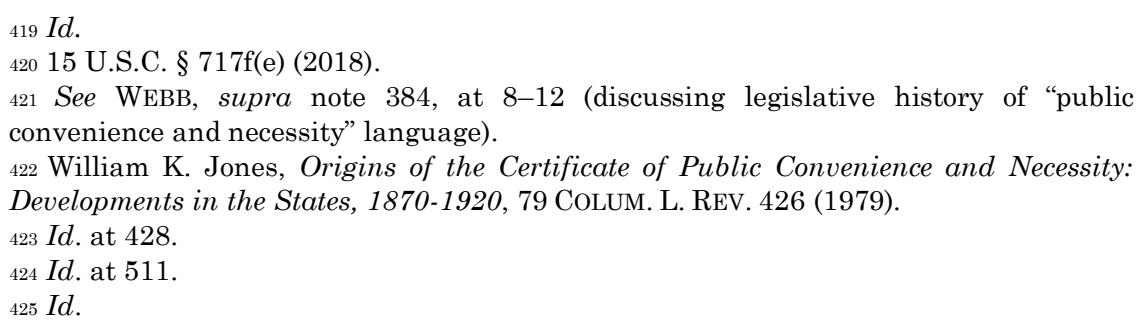


Consistent with that history, courts have interpreted the public convenience and necessity standard under the NGA to encompass "all factors bearing on the public interest." 426 This capacious authority provides FERC with substantial discretion. In a 1961 case considering FERC's Section 7 authority, the Supreme Court held that as "the guardian of the public interest," FERC is entrusted "with a wide range of discretionary authority." 427 Given its "wide discretion to balance competing equities," ${ }_{228}$ FERC can elect to consider certificate applications on the basis of whether a project will maximize social welfare as measured by comparing the combination of monetized and qualitative costs and benefits. 429 The text of the NGA does not explicitly prohibit FERC from monetizing or quantitatively comparing the benefits and costs of a project as its chosen method for evaluating the public interest, and statutory silence cannot be read as a prohibition.430

As the Supreme Court described, "the term 'public convenience and necessity' connotes a flexible balancing process, in the course of which all the factors are weighed prior to final determination." 431 A cost-benefit analysis framework would involve FERC quantification and monetization of costs and benefits when possible. Tools such as break-even analysis and expert judgment can be used to evaluate those costs and benefits

426 Atl. Refining Co. v. Pub. Serv. Comm'n of N.Y., 360 U.S. 378, 391 (1959). See also Mo. Pub. Serv. Comm'n v. FERC, 234 F.3d 36, 38 (D.C. Cir. 2000) (noting that issuing a certificate of public convenience and necessity to transport or sell natural gas requires the Commission to "evaluate all factors bearing on the public interest." (quoting Atl. Refining Co., 360 U.S. at 391)); Cascade Nat. Gas Corp. v. FERC, 955 F.2d 1412, 1421 (10th Cir. 1992) (when evaluating a project, "the Commission must consider all factors bearing on the public interest, not simply those immediately relating to the objects of its jurisdiction.").

${ }_{427}$ Fed. Power Comm'n v. Transcon. Gas Pipeline Corp. (Transco), 365 U.S. 1, 7 (1961) (quoting United States v. Detroit \& Cleveland Navigation Co., 326 U.S. 236, 241 (1945). ${ }_{428}$ Columbia Gas Transmission Corp. v. FERC, 750 F.2d 105, 112 (D.C. Cir. 1984).

429 See Entergy Corp. v. Riverkeeper, Inc., 556 U.S. 208, 217 (2009) (holding that under Chevron v. Nat. Res. Def. Council, 467 U.S. 837 (1984), agency interpretation of its obligation to set standards based on the "best technology available" reasonably could be read to permit setting standards based on a cost-benefit analysis).

${ }_{430}$ Entergy Corp., 556 U.S. at 222 ("The inference that respondents and the dissent would draw from the silence is, in any event, implausible, as $\S 1326(\mathrm{~b})$ is silent not only with respect to cost-benefit analysis but with respect to all potentially relevant factors. If silence here implies prohibition, then the EPA could not consider any factors in implementing § 1326(b)—an obvious logical impossibility.”).

${ }_{431}$ Transco, 365 U.S. at 23. 
that cannot be readily quantified and monetized. This is the hallmark of a process that is "flexible" while also ensuring that "all factors" are "weighed" as part of a pipeline certificate decision.

The use of cost-benefit analysis in order to make decisions that maximize social welfare can also help FERC meet its analytical obligations under the NGA. When FERC "articulate[s] the critical facts upon which it relies" to review public convenience and necessity, "[a] passing reference to relevant factors . . . is not sufficient to satisfy the Commission's obligation to carry out 'reasoned' an 'principled' decision making. [Courts] have repeatedly required the Commission to 'fully articulate the basis for its decision." 432 Systematic analysis that quantifies and monetizes the benefits and costs that FERC considers to be relevant, and then weighs those benefits and costs against each other will help FERC "fully articulate" its decision and avoid the sense that it gave only "passing reference" to some of the factors bearing on the public interest.

\section{The Scope of Costs and Benefits FERC May Consider}

By directing FERC to consider "all factors," court decisions interpreting the NGA are consistent with a decision making framework that seeks to maximize social welfare by looking broadly at the scope of costs and benefits that may be the result of a project. Moreover, in order to consider the public interest, FERC must necessarily look beyond the private interests of the applicant.433 Cost-benefit analysis allows FERC to consider a broad set of social interests that will be affected by new pipeline infrastructure and exercise its judgment to approve a project only when the benefits outweigh the costs on net.

Recently, in Michigan v. EPA, the Supreme Court reasoned that it would not be rational for EPA to adopt an interpretation of "appropriate" in a way that permits the agency to ignore costs

432 Mo. Pub. Serv. Comm'n v. FERC, 234 F.3d 36, 41 (D.C. Cir. 2000) (citations omitted). ${ }_{433}$ FERC may not presently be required to evaluate the benefits of pipelines beyond those that accrue to market participants. Minisink Residents for Envtl. Pres. \& Safety v. FERC, 762 F.3d 97, 111 n.10 (D.C. Cir. 2014) (holding that FERC was not required to look beyond the market need reflected by the applicant's existing contracts with shippers to establish a project's public benefits). However, nothing prohibits it from doing so and, given the opportunity, it should consider the broader benefits of additional natural gas supply into a market. 
because "appropriate" is "the classic broad and all-encompassing term that naturally and traditionally includes consideration of all the relevant factors." 434 So too would it be irrational for FERC to adopt an interpretation that permits the agency to ignore key categories of costs (or benefits) when evaluating the public convenience and necessity of a natural gas project based on "all relevant factors."

As in the case of electric sector regulation, FERC has cited to NAACP v. FPC to suggest that FERC may be constrained from treating the public convenience and necessity test as a question of pure welfare maximization. 435 But the question at issue in $N A A C P$ did not involve the proper interpretation of "public convenience and necessity." Rather, the Court considered whether either the term "just and reasonable" as used in the ratemaking sections of the FPA and NGA or the term "public interest" as used in the general purpose sections of the FPA and NGA were sufficient to justify Commission rulemaking establishing non-discrimination requirements for public utilities. 436 As discussed above, "public convenience and necessity" has historically included consideration of a broad range of effects on parties beyond just the producers and consumers involved in electric and natural gas transactions.

Moreover, the constraint that FERC should look to the purposes of the NGA when evaluating the scope of its obligations to advance the public interest need not meaningfully limit FERC's use of cost-benefit analysis as its decision making framework. All relevant costs and benefits, including the benefits to consumers of natural gas, the costs of pipeline construction, and social costs such as environmental and climate consequences of a project all clearly fall within the purposes of the NGA. They are therefore readily available for FERC to consider as part of a welfare-maximizing framework.

${ }_{434}$ Michigan v. U.S Envtl. Prot. Agency, 135 S. Ct. 2699, 2707 (2015) (quoting White Stallion Energy Center, LLC v. U.S. Envtl. Prot. Agency, 748 F.3d 1222, 1266 (D.C. Cir. 2014) (Kavanaugh, J., concurring in part) (emphasis added).

435 Dominion Transmission, Inc., 163 FERC $~ 61,128$, at P 43 (2018) [hereinafter New Market Rehearing Order] (arguing that NAACP, 425 U.S. 662, supports FERC's position that it need not consider upstream and downstream greenhouse gas emissions under the NGA).

${ }_{436}$ NAACP, 425 U.S. at 666. 
The ability of new pipeline infrastructure to enable additional consumption of natural gas and lower prices for consumers is at the heart of the NGA. As the Supreme Court explained in $N A A C P$, the "principal purpose" of the NGA is "to encourage the orderly development of plentiful supplies of . . natural gas at reasonable prices." 437 The purposes of the NGA are also broad enough to permit FERC to consider, monetize, and weigh a wide range of social impacts.438 This includes the benefits and costs associated with the downstream use of natural gas, such as the effect on gas prices and the environmental effects of gas use.

In a 1961 case, the Supreme Court tacitly acknowledged that the downstream effects of natural gas pipeline construction were an important part of the Commission's public interest determination. In FPC v. Transcontinental Gas Pipe Line Corp. (Transco), the Court considered a challenge to a Commission decision to deny a proposed pipeline project a certificate of public convenience and necessity based on an evaluation of "policy" factors such as the pipeline's effect on downstream conservation and end use price of natural gas. 439 The Court held that Congress intended the Section 7 language to give the Commission broad (though not unlimited) discretion in evaluating the public interest and that the Commission acted within that authority even when considering how a pipeline would affect activity that was not within its jurisdiction.440 This included the downstream costs of inefficient use of natural gas and increasing retail prices. 441 The Court also adopted reasoning that downstream air pollution was a public interest factor that the Commission could consider when it accepted the Commission's expert judgment that the pipeline at issue would not sufficiently advance clear air objectives to overcome the Commission's concerns about inefficient end use. 442

${ }_{437} I d$. at 670.

438 See Fla. Gas Transmission Co. v. FERC, 604 F.3d 636, 650 (D.C. Cir. 2010) (Brown, J., concurring in part and dissenting in part) (FERC's "section 7 duty to consider the public interest is broader than promoting a plentiful supply of cheap gas, as important as that policy may be.").

439 Transco, 365 U.S. at 23.

${ }_{440} I d$. at 26,28

${ }_{441} I d$. at 22, 25; id. at 41-42 (Harlan, J., concurring in part and dissenting in part)

442 Id. at 30; id. at 42 (Harlan, J., concurring in part and dissenting in part) (explaining that on remand the Commission should take a closer look at whether downstream air 
The Supreme Court's later decision in NAACP does not undermine the decision in Transco that the Commission can consider social costs of additional pipeline capacity when evaluating whether a project is in the public interest. As the Supreme Court explained in NAACP, the Commission's primary role under the NGA is to "encourage the orderly development of plentiful supplies . . . of natural gas at reasonable prices." 443 The use of "orderly" suggests reasoned decision making, which necessarily entails considering factors that are the consequence of a particular action at issue. In a footnote, the Supreme Court also specifically identified "subsidiary purposes" of the NGA that "the Commission has authority to consider," including "conservation, environmental, and antitrust questions." 444

Numerous courts have used these citations to confirm that FERC has authority to consider a range of benefits and costs implicated by a pipeline project, including environmental costs, when evaluating a certificate application.445 And, if there was any doubt, in the 2017 case overturning FERC's approval of the Sabal Trail Project, the D.C. Circuit made clear that consideration of downstream environmental consequences of jurisdictional pipelines facilities is part of FERC's obligation to consider the public interest under Section 7: "Congress broadly instructed the agency to consider the public convenience and necessity when evaluating applications to construct and operate interstate pipelines. FERC will balance the public benefits against the adverse effects of the project, including adverse environmental effects" 446 In the face of FERC intransigence, the D.C. Circuit recently reaffirmed that position. 447

Therefore, while FERC may not be permitted to include social harms such as discrimination into a cost-benefit framework, it is well within its statutory mandate to monetize and then weigh

pollution improvements are sufficient to overcome other concerns in order to justify approval of the certificate).

${ }_{443}$ NAACP, 425 U.S. at 669-70 (emphasis added).

${ }_{444} I d$. at 670 n.6.

${ }_{445}$ E.g., Pub. Util. Comm'n of State of Cal. v. FERC, 900 F.2d 269, 281 (D.C. Cir. 1990); Minisink Residents for Envtl. Pres. \& Safety, 762 F.3d at 101; Myersville Citizens for a Rural Cmty, Inc. v. FERC, 783 F.3d 1301, 1307 (D.C. Cir. 2015); Sierra Club v. U.S. Dep't of Energy, 867 F.3d 189, 202 (D.C. Cir. 2017).

${ }_{446}$ Sierra Club v. FERC (Sabal Trail), 867 F.3d 1357, 1373 (D.C. Cir. 2017) (emphasis added and citations and quotations omitted).

${ }_{447}$ Birckhead v. FERC, 925 F.3d 510, 519 (D.C. Cir. 2019). 
a wide range of economic and environmental benefits and costs associated with a proposed interstate natural gas pipeline.

\section{Applying Cost-Benefit Analysis}

This section describes how cost-benefit analysis can be incorporated into FERC's existing economic test, identifies economic tools that FERC can use to quantify and monetize relevant costs and benefits, and addresses FERC's arguments for why it does not use cost-benefit analysis in pipeline certificate proceedings.

1. Categories of Costs and Benefits to Consider

FERC's decision not to monetize the benefits and costs of particular pipeline projects has limited its ability to transparently and systematically balance the costs and benefits of pipeline projects. FERC's qualitative approach leaves it to make subjective judgments about whether the benefits of a project outweigh the costs. This has reduced the legitimacy of FERC's pipeline certificate approvals.448 On the other hand, by putting the benefits and costs of a project into a common metric of dollars, FERC can more transparently evaluate whether the public benefits of additional natural gas supply outweigh the private and social costs caused by new pipeline projects. This can be done by embracing the principles of FERC's economic test while shifting from qualitative and subjective balancing to a more quantitative and formalized approach.

This section describes how FERC can consider the benefits and costs of pipeline projects through the lens of cost-benefit analysis.

\section{a. Expanding Availability and Lowering Price of Natural Gas}

The primary benefit of new natural gas infrastructure is the expanded availability of natural gas. This includes supply of gas to new consumers and the reduction in price of gas in a particular market for existing consumers.

${ }_{448}$ Spire STL Certificate Order, supra note 377 (Glick, Comm'r, dissenting) (explaining that FERC's "anemic review ... lends credence to the critique that [FERC] does not meaningfully review section 7 applications.”). 
Under FERC's current approach, FERC does not actually consider the benefits of additional gas supplies; it instead merely relies on precedent agreements as a proxy for the existing of benefits. Cost-benefit analysis can help FERC more systematically and transparently account for the benefits of new pipelines as compared to FERC's current approach of using precedent agreements.

The fact that a natural gas-fired electric generator, chemical company, or natural gas distribution utility is willing to sign a contract for pipeline service provides little information on the magnitude of a project's benefits beyond the fact that they are expected to exceed the private costs of constructing and operating the project. Lacking such an estimate for the magnitude of benefits, FERC is unable to rationally evaluate whether the project's benefits exceed the total costs of the project, including the external costs to parties other than the customer. Without using consistent metrics, FERC may approve projects where the total costs exceed the benefits.

The existence of a contract to ship gas between two private entities says little about the magnitude of public benefit that will result from a project.449 Contracts may both overestimate and underestimate the public benefits of new pipeline infrastructure. They overestimate benefits if existing consumers see higher transportation costs without seeing the benefits of additional gas. This is at high risk of occurring when the customer is a gas distribution company that is an affiliate of the pipeline developer. Contractual agreements between these entities may reflect market power or regulatory capture, rather than the existence of true private benefits.450 But they will understate the benefits by assuming only the parties to the contract see benefits. Pipelines benefit more than just the customers who will directly receive natural gas transportation service. A number of areas, particularly in the northeastern United States, have pipeline constraints that push the price of natural gas

${ }_{449}$ Spire STL Certificate Order, supra note 377, at 72 (characterizing contracts to be "substantial and sufficient evidence of need") (emphasis added).

450 See Susan F. TIERnEy, ANALYSis Group, FERC's CERTIFICATION OF NEW INTERSTATE Natural Gas Facilities: Revising the 1999 Policy Statement For 21St Century CONDITIONS 21-22 (2019), (describing and citing to arguments for giving little weight to affiliate precedent agreements). 
higher than it would be with additional pipeline capacity. 451 Additional pipeline construction can alleviate constraints and push natural gas prices down.452 These low prices do not only benefit the customers of a newly constructed pipeline but benefit all customers in the region.

By monetizing the public benefits of additional natural gas supplied to the market, FERC can more transparently evaluate the benefits of a project. As FERC explained in the 1999 Policy Statement, the public benefits of additional transportation capacity primarily consist of "meeting unserved demand" and "lower costs to consumers." 453 These two benefits can be quantified and monetized. New pipeline infrastructure benefits consumers by providing access to natural gas where none was available before. The economic value of additional natural gas that a project brings to market represents these benefits.454 As explained infra, tools are available to FERC to analyze the extent to which new pipeline infrastructure will bring additional gas supplies to market. FERC can, therefore, calculate the monetized economic value of additional natural gas supplies by multiplying the expected net change in natural gas supply caused by a project by the price of the natural gas. New pipeline

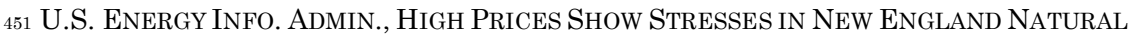
GAS DELIVERY SYSTEM (Feb. 7, 2014), https://www.eia.gov/naturalgas/

review/deliverysystem/2013/pdf/newengland_natgas.pdf [https://perma.cc/T2GYZVQR]; U.S. FED. ENERGY REGUlATORY COMM'N, DOCKET No. AD-6-03-000, WinTER 2018-19 ENERGY MARKET ASSESSMENT 6 (Oct. 18, 2018) (showing expected pipeline constraints and high regional natural gas prices for New England for Winter 2018-2019). 452 See ICF InT'L, NATURAL Gas Pipeline AND Storage Infrastructure Projections Through 2030 at 43 (2009) https://www.ingaa.org/File.aspx?id=10509 [https://perma.cc/4UW2-QGDQ] ("The term basis refers to natural gas price differentials between regions. Pipeline rates and tolls do not determine basis. Instead, basis is determined by the opportunity costs to move natural gas between locations. When there is significant excess pipeline capacity between markets ... basis differentials can be quite low.... Conversely, in a market where there is a deficiency of pipeline capacity ${ }^{2}$... basis is the market signal that represents the true opportunity cost between regions .... Incremental supply and pipeline capacity will tend to reduce basis between regions.”).

4531999 Policy Statement, supra note 16, at 25.

${ }_{454}$ Note that the benefits of the project are limited to the amount of incremental natural gas provided by the project and not necessarily the total amount of natural gas that FERC expects the pipeline to transport. This is because some amount of transported gas may displace gas that would have been transported by other pipelines. See Spire STL Certificate Order, supra note 377, at P 107 ("We acknowledge that without new demand, existing pipelines in the area will likely see a drop in utilization once supplies begin to flow on the project"). 
infrastructure also benefits existing gas consumers by lowering natural gas prices. The change in natural gas prices caused by a pipeline, multiplied by the amount of natural gas supplied in the region represents these benefits. As explained infra, economic tools are also available to analyze how new gas infrastructure will influence regional natural gas prices.

\section{b. Construction and Operational Costs}

An important set of costs that FERC can easily quantify and monetize are the private costs to construct, operate, and maintain a proposed project. Because capital costs are an important factor for determining initial cost-of-service rates for new projects, FERC regulations already require applicants to provide estimated capital costs, 455 and FERC discloses those costs in certificate orders.456 Construction and operating costs are also often included in a project's EIS. 457 However, while these costs are quantified and monetized, FERC's decision not to use cost-benefit analysis limits the extent to which they can be combined with other costs and compared to the benefits of a project.

\section{c. Landowner and Community Costs}

When a certificate is issued, pipeline developers are granted authority to exercise eminent domain to take lands necessary to construct and operate the pipeline.458 Local landowners face a cost in the form of lost welfare from the reduced use of, or ownership of, their property. Additionally, whenever a taking

45518 CFR $\S 157.14(a)(14)$ (requiring submission of capital costs).

${ }_{456}$ E.g., Spire STL Certificate Order, supra note 377, at P 130 (providing cost estimates of \$220,276,167); DTE Midstream Appalachia, LLC, 162 FERC ๆ 61,238, at PP 19-20 (2018) (discussing costs, including return on equity of Birdsboro Pipeline Project); Columbia Gas Transmission, LLC, 164 FERC $\uparrow$ 61,036, at P 17 (2018) (discussing firstyear cost of service for project); Northwest Pipeline LLC, 164 FERC 9 61,038, at P 4 (2018) (estimating cost of project to be $\$ 47,288,729$ ); Fla. Gas Transmission Co., 13 FERC ๆ $63,048,65,247$ (1980) (discussing cost estimates of four alternative pipeline projects). 457 See, e.g., Final EnVIRonmental ImPaCt Statement for the Greenbrier PiPeline PROJECT, supra note 392, at 3-177 (describing construction costs); FED. ENERGY REgulatory COMm'N, Final EnVIRONMENTAL IMPACT STATEMENT FOR Midship Pipeline Company, LLC-Midcontinent Supply Header Interstate Pipeline Project, Docket No. CP17-458-000, at 4-119 to 4-120 (2018) (estimating pipeline construction and operational labor costs).

45815 U.S.C. $\S 717 f(h)$. 
occurs, the pipeline company is required to provide just compensation to the landowner, which constitutes a benefit to the landowner.459 A cost benefit analysis can include both these costs and benefits in order to inform FERC and the public about the effect of the infrastructure project on local landowners. And to the extent there is a systematic difference between landowner welfare losses and the compensation provided through eminent domain, that net cost (or benefit) should be weighed by FERC when evaluating the certificate.

Pipelines also impose costs on communities through which they travel. A new pipeline can lower property values in a community, with diminution extending beyond the property owner whose land is taken by the pipeline company.460 Those landowners would not receive the benefit of just compensation that landowners whose property is taken through eminent domain receive. The change in community property values can be estimated and incorporated in a cost-benefit analysis.

In addition, pipelines may pose significant environmental justice concerns.461 The construction and operation of pipelines can put vulnerable and disadvantaged communities at greater risk of air pollution, water pollution, and safety consequences. Environmental justice concerns are difficult to monetize and incorporate directly into a cost-benefit analysis. 462 However, FERC could employ tools such as equity weighting to monetize some distributional consequences of proposed pipelines, 463 consider issues related to "equity, dignity, fairness, and distributive impacts" qualitatively within the cost benefit

${ }_{459}$ U.S. CONST. amend. V ("nor shall private property be taken for public use, without just compensation") (emphasis added).

460 See Spencer Phillips et Al., Key-Log Economics, Economic Costs of the PENNEAST PIPELINE 6-7 (JAN. 2017), https://www.delawareriverkeeper.org/sites/ default/files/Public\%20Participation\%20Undermined\%20Attachment\%2018.pdf [https://perma.cc/3UFT-UC9Q]. But see Louise Wilde et al., A Long-term Study of the Effect of a Natural Gas Pipeline on Residential Property Values, 22 J. REAL EsT. LITERATURE 47 (2014).

461 See Friends of Buckingham v. State Air Pollution Control Bd., 947 F.3d 68, 87-92 (4th Cir. 2020) (vacating air pollution permit for Atlantic Coast Pipeline due to failure to account for environmental justice concerns).

462 See Stephanie H. Jones, Greater Than the Sum of Its Parts: The Integration of Environmental Justice Advocacy and Economic Policy Analysis, 26 N.Y.U. ENVTL. L.J. 402, 413-16 (2018).

463 See id. at $421-26$. 
framework, 464 or present and consider environmental justice issues as part of a distributional analysis presented alongside a cost-benefit analysis. 465

\section{d. Reliability}

Additional pipeline capacity can also improve reliability of electric service by reducing the chance that demand spikes caused by extreme weather disrupt the availability of natural gas for electric generation.466 Improvements to gas and electric system reliability may be more difficult to monetize. As explained in Part III, supra, FERC can rely on methodologies to assess the likelihood of natural gas fuel disruption and the consequences of that disruption.467 FERC can then monetize the reduced risk of supply disruption. However, if a sophisticated analysis that monetizes the reliability improvement of additional pipeline capacity is not feasible for an individual pipeline certificate proceeding, FERC would still benefit from additional quantification of the potential reliability benefits of a particular pipeline and can use its expert judgment when weighing these nonmonetized benefits along with other monetized benefits and costs as part of a comprehensive costbenefit analysis.

${ }_{464}$ See Exec. Order No. 13,563 § 1(c), 76 Fed. Reg. 3821, 3821 (Jan. 18, 2011). 465 See Richard L. Revesz, Regulation and Distribution, 93 N.Y.U. L. REV. 1489, 1570 (2018).

466 See ISO NEW ENGLAND, OPERATiOnal Fuel-Security ANAlysis (2018), https://www.iso-ne.com/static-assets/documents/2018/01/20180117_operational_fuelsecurity_analysis.pdf [https://perma.cc/N5P7-7WYH] (finding that, under certain conditions, pipeline constraints when combined with extreme weather and greater than expected generator retirements can pose reliability problems). This may not always be true and so FERC should quantify the specific reliability costs and benefits rather than assuming general benefits. See PJM InTERCONNECTION, FuEL SECURITY ANALYSIS: A PJM RESILIENCE INITIATIVE 1, 38 (2018) (showing that pipeline disruptions only marginally change expected system reliability as compared to other more important factors).

467 Existing electric system operator analyses have attempted to analyze the consequences of pipeline disruptions. See PJM InTERCONNECTION, supra note 466, at 38. These models do not evaluate the probability of their chosen scenarios and so would only provide a component to the analysis FERC needs quantify and monetize the reliability benefits of additional pipeline infrastructure. 
e. Environmental Costs and Benefits

A set of costs and benefits that FERC currently fails to fully consider in its balancing test involve environmental consequences. FERC acknowledges that the balancing test is an "economic test" that excludes environmental considerations.468 But FERC asserts that even if it does not directly weigh the environmental consequences detailed in its NEPA review, it considers them when deciding whether a project would serve the public convenience and necessity. FERC asserts that it will reject an application if it "finds a project to be environmentally unacceptable." 469 However, FERC does not define what would constitute an unacceptable environmental consequence that would be sufficient to take such an action.470

Cost-benefit analysis can provide a framework to more rationally evaluate whether a project is "environmentally unacceptable." By putting environmental consequences into the same metric as other costs and benefits-dollars-cost-benefit analysis can facilitate the direct weighing of the project's environmental costs against other benefits and costs. 471 Directly comparing the environmental costs and benefits of a project with other costs and benefits would limit the possibility that FERC places too much or too little weight on this category of consequences. This is because failing to quantify the effects of an action often leads agencies to ignore the consequences entirely when making decisions.472

The prospect that unquantified costs and benefits are at risk of being undervalued is supported by FERC's treatment of the

468 See 1999 Policy Statement, supra note 16, at 61,745, 61,748 (stating that the landowner and surrounding community interests that FERC considers in its balancing test "are different in character from other environmental issues considered under [NEPA]").

469 Millennium Pipeline Co., 141 FERC 9 61,198, at P 44 (2012).

470 One approach that FERC has taken is to consider environmental costs to be acceptable so long as they are consistent with other state and federal environmental requirements such as Clean Air Act permits. See id. at P 54. However, this approach ignores the fact that a project that complies with environmental permitting requirements may nonetheless impose costs on society. If these residual costs outweigh the public benefits, the project would not be rationally justified even if it complied with relevant environmental laws.

${ }_{471}$ As explained infra, environmental economics has developed tools that FERC can use to monetize environmental costs and incorporate them into its balancing test.

472 See Revesz, supra note 53, at 1434-35. 
climate damages caused by pipeline projects. FERC has refused to consider the climate damage that results from the greenhouse gases emitted by upstream production and downstream combustion of natural gas transported by a pipeline.473 Nor does FERC consider the potential environmental benefits of enabling additional natural gas consumption displacing higher emitting alternatives such as coal. However, new pipeline infrastructure can result in additional emissions that contributes to climate change, or it can result in displacement of higher emitting alternatives. For the same reason that increasing the amount of natural gas that can be transported from producing regions to consumers will produce benefits such as lower consumer prices, new transportation capacity results in additional greenhouse gas emissions both upstream and downstream of a pipeline. Additional natural gas consumption is only a benefit if it is used. Any time natural gas is used by combusting it, it will produce greenhouse gas emissions, 474 and virtually all natural gas use is through combustion.475 Moreover, as a basic principle of supply and demand, greater demand for natural gas yields increasing financial incentives to develop new supplies. 476 Due to leaks during the production process, additional production also results in fugitive emissions of methane, 477 a potent greenhouse gas. 478 However additional transportation of natural gas use can also

${ }_{473}$ See Webb, supra note 384, at 28-31.

${ }_{474}$ U.S. EnVtl. Prot. Agency, Inventory of U.S. Greenhouse Gas Emissions And Sinks: 1990-2016, ANNEX 2 Methodology AND DATA FOR ESTIMATING CO 2 EMissions FROM Fossil FUEL COMBUSTION, A32, A74-A76, https://www.epa.gov/sites/production/ files/2018-01/documents/2018_annex_2.pdf [https://perma.cc/SCP8-V2KQ] (describing EPA's methodology for determining the carbon content of pipeline gas that will be released to the atmosphere when combusted). See also U.S. ENVTL. Prot. AGENCY CEnTER for Corporate Climate LeAdership, EMIssion FACTORS For GreEnhouse GAS INVENTORIES (2018), https://www.epa.gov/sites/production/files/2018-03/docu ments/emission-factors_mar_2018_0.pdf [https://perma.cc/8C5P-TN3Z] (providing emission factors for $\mathrm{CO}_{2}, \mathrm{CH}_{4}$, and $\mathrm{N}_{2} \mathrm{O}$ that results from natural gas combustion).

475 See Jayni Hein et Al., Inst. For Policy Integrity, Pipeline Approvals and Greenhouse Gas EMissions 25 (2019) (finding that 97\% of natural gas is combusted). 476 See N. GREgory MaNKIW, PRinciples of ECONOMICS 74-78, 80-81 (5th ed. 2008).

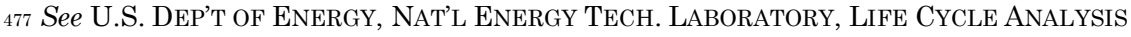
of NATURAl Gas EXTRACTION AND Power GENERATION, DOE/NETL-2015/1714 at 1323, 37 (Aug. 30, 2016) (discussing causes of emissions and estimating emission rates from natural gas extraction and processing).

${ }_{478}$ See U.S. EnVTl. Prot. Agency, National Level U.S. Greenhouse Gas InVentory 1990-2016: FAST FACTS 3 (2018), https://www.epa.gov/sites/production/files/201804/documents/9509_fastfacts_20180410v2_508.pdf [https://perma.cc/6T7L-8KJ5]. 
be an environmental benefit. Additional gas enables construction of new natural gas fired power generators and lower natural gas prices can increase the utilization of existing natural gas-fired power generators. Depending on the region, electricity mix, and relative costs, this, in turn, can displace high-emitting coal, or oil-fired generation, and reduce overall emissions.

The climate consequences of additional upstream and downstream natural gas are often substantial. For example, in a 2017 Order granting a certificate for the NEXUS Project, an interstate pipeline system to bring natural gas from the Appalachian Basin to consumers in northern Ohio, southeastern Michigan, and Ontario, Canada, FERC estimated that if the full capacity of the pipeline were utilized during a year and combusted-what FERC has called a "full burn analysis" 479 - the project could result in up to 22.3 million metric tons per year of carbon dioxide-equivalent emissions.480 Each year of emissions from the project could cause over $\$ 900$ million worth of climate damages.481 But after a series of orders where FERC quantified these emissions, 482 in 2018 FERC established a policy that it will evaluate upstream and downstream greenhouse gas emissions in only limited circumstances.483 Because FERC only looks at

${ }_{479}$ SMP Project Remand Order, supra note 62, at P 24.

480 See NEXUS Gas Transmission, LLC, 160 FERC @ 61,022, at PP 172-73 (2017) (estimating 0.8 million metric tons per year ("tpy") of carbon dioxide-equivalent ("CO2e") emissions from operation, 1.2 million metric typ CO2-e from extraction of natural gas, 2.4 million metric tpy $\mathrm{CO} 2$-e from gas processing, and 17.9 million metric tpy CO2-e from end-use combustion). Notably, these may not all be additional emissions. FERC's analysis assumed full utilization of the NEXUS Pipeline System and that transported gas would all be additional. See id. at P 173. In fact, the pipeline is not likely to be used at full capacity at all times and natural gas transported by the NEXUS system may displace gas transported in other pipeline systems or other fossil fuels that have higher emission rates. Id.; SMP Project Remand Order, supra note 62, at P 24. A more accurate estimate of the net emissions associated with the system would require a more sophisticated analysis of the type described infra.

481 The federal Interagency Working Group on the Social Cost of Greenhouse Gases has provided a "central value" of $\$ 42$ per ton of greenhouse gases emitted in 2020 in year 2007 dollars. See Interagency Working Group, supra note 324, at 4. As explained supra, this value captures that future stream of climate damages and discounts future damages back at a $3 \%$ discount rate. 22.3 million tons multiplied by $\$ 42$ per ton equals $\$ 936.6$ million.

482 See New Market Rehearing Order, supra note 435, at PP 1 n.3, 3 n.6. (LaFleur, Comm'r, dissenting) (listing FERC orders that calculated upstream and downstream emissions).

483 See id. at P 44. 
environmental impacts included in its NEPA review when evaluating whether a project supports the public convenience and necessity, FERC also fails to consider these impacts under the NGA.484

FERC has argued that it is not able to evaluate upstream and downstream greenhouse gas emissions because there is no wellaccepted metric for determining whether a given level of emissions is significant.485 Monetization, however, provides just such a tool. By using a common metric, FERC can weigh the climate consequences (positive or negative) against the benefits of a project and approve a pipeline application when doing so maximizes social welfare-that is, when the benefits exceed the costs.

Monetization of the climate consequences of a proposed project and alternatives would allow FERC to better assess the tradeoffs between approving or denying a project, or between competing alternatives. 486 FERC can then distinguish between projects that have substantial climate consequences and limited public benefits and those that have substantial public benefits with limited or positive climate consequences. Even those projects that have significant consequences may be in the public interest if the public benefit of additional natural gas capacity is substantial. But FERC cannot rationally make such a decision without actually weighing the full suite of readily discernible consequences against the discernible benefits of a project.

Climate damages are not the only environmental consequence that can be factored into a cost-benefit analysis. Pipeline development may impose ecological harm by disturbing

${ }_{484} I d$. at $\mathrm{P} 43$ ("We are not aware of any basis that indicates the Commission is required to consider environmental effects that are outside of our NEPA analysis of the proposed action in our determination of whether a project required for the public convenience and necessity under section 7(c).”); but see id. at 9 61,706-07 (LaFleur, Comm'r, dissenting in part) ("NEPA does not circumscribe the public interest standard under the NGA. Even assuming that the majority is correctly interpreting the Commission's NEPA responsibilities, I believe the Commission has broad discretion in considering factors bearing on our public interest determination.").

485 Id. at P 67 ("Without an accepted methodology, the Commission cannot make a finding whether a particular quantity of greenhouse gas emissions poses a significant impact on the environment, whether directly or cumulatively with other sources, and how that impact would contribute to climate change.").

${ }_{486}$ The evaluation of competing alternatives can play a large role in FERC's collaborative pre-filing review option. See 18 C.F.R. § 157.21. Almost all projects elect to take advantage of this process. See Christin et al., supra note 358, at 130-31. 
undeveloped or otherwise preserved terrain,487 or by disturbing critical habitat needed by an endangered or threated species.488 The economic value of these harms can be measured using tools such as ecosystem services. 489

2. Economic Tools

Economic tools are available that would allow FERC to evaluate the economic and social consequences of proposed pipeline projects and to put those consequences in monetized terms so that they can be transparently balanced in a costbenefit framework.

In order to quantify and monetize the benefits and costs of a natural gas project, FERC must estimate how the project will influence upstream production and downstream consumption of natural gas, and whether the natural gas supplied by a pipeline will displace consumption of other resources. This type of analysis is enabled by sophisticated but available models of the natural gas system. Using these models, FERC can estimate the extent to which a pipeline will alleviate bottlenecks, increase supplies to a market, and change regional prices of natural gas that are available to existing customers. This information will enable FERC to calculate the benefits of a new pipeline project, including the economic benefits of additional natural gas consumption and the reduction in prices for existing consumers.

A variety of modeling tools are available to FERC. ICF International has produced the Gas Market Model, which can quantify changes in regional natural gas prices caused by changes in gas infrastructure.490 This model was originally used to simulate gas market changes that would result from the completion of a new pipeline connecting Alberta, Canada and Chicago and subsequently has been used to complete "[a]nalyses

487 See Sharon Buccino \& Gillian Giannetti, A Walk in the Woods: Pipelines and the Appalachian Trail, NRDC.ORG (Jan. 22, 2020), https://www.nrdc.org/experts/gilliangiannetti/walk-woods-pipelines-and-appalachian-trail [https://perma.cc/WRT6-9S4U] (describing potential disruption to National Park Service managed land from gas pipeline development).

488 See Robert Walton, 4th Circuit Court Vacates Permits for Dominion's Atlantic Coast Pipeline, UTIL. Dive (July 29, 2019), https://www.utilitydive.com/news/4th-circuit-courtvacates-permits-for-dominions-atlantic-coast-pipeline/559692/ [https://perma.cc/WPG5KWAY].

489 See supra notes 163 and 164 and accompanying text.

490 ICF INT'L, supra note 452, at 96-100 (describing the Gas Market Model). 
of different pipeline expansions." 491 The Gas Market Model also includes construction and operation cost estimates that FERC can use to estimate the private costs of pipeline construction if certificate applicants have not provided sufficiently specific information. The Gas Market Model has been used recently by a number of agencies to assess the energy market implications of infrastructure approvals. 492

DOE's Energy Information Agency developed the National Energy Modeling System ("NEMS"), which is a publiclyavailable integrated energy market model.493 NEMS includes a number of modules, including a Natural Gas Transmission and Distribution Module, which "models the transmission, distribution, and pricing of natural gas," subject to inputs provided in other modules of the model such as natural gas demand and production.494 This includes "track[ing] the flows of natural gas, and determin[ing] the associated capacity expansion requirements in an aggregate pipeline network[.]" 495 NEMS is divided into twelve regions and produces regional natural gas price estimates. 496 The Surface Transportation Board's use of NEMS to evaluate the economic and environmental impact of approving rail lines to transport coal resources has been upheld by the Eighth Circuit. 497 These models present FERC with the tools it needs to evaluate the changes in gas supply and price that can be used to calculate the expected benefits of a proposed project.498

491 See id. at 96.

492 See Surface Transp. BD., Tongue River R.R. Co., Inc., Draft Envtl. Impact STATEMENT C.5-26 (2015) [hereinafter TONGUE RIVER], https://www.stb.gov/decisions/ readingroom.nsf/UNID/E7DE39D1F6FD4A9A85257E2A0049104D/\$file/AppC_CoalPro duction.pdf (describing use of Gas Market Model, in combination with other ICF International modeling tools to assess market impacts of approval of an additional rail line to transport coal).

493 U.S. Energy Info. Admin., AnN. Energy Outlook 2016 with Projections to 2040 E-1 (2017) [hereinafter EIA, ANNUAL ENERGY OUTLOOK], https://www.eia.gov/outlooks/ aeo/pdf/0383(2016).pdf [https://perma.cc/LF6X-NQDZ] (describing NEMS model).

${ }_{494} I d$. at E-4 to E-5.

$495 I d$. at E-4.

496 Id. at E-4 to E-5.

497 Mayo Found. v. Surface Transp. Bd., 472 F.3d 545, 555-56 (8th Cir. 2006).

498 For a useful comparison of various comparable models, see generally PETER H. Howard, Institute For POLICY INTEGRITY, THE BuREAu of LAND MANAGEMENT'S Modeling Choices for the Federal Coal Programmatic Review (2016), http://policyintegrity.org/publications/detail/BLM-model-choice [https://perma.cc/X3RC$\mathrm{J} 72 \mathrm{H}]$. 
Economic tools are also available to quantify and monetize the climate consequences of new pipeline infrastructure. As described in Part III, supra, the Social Cost of Carbon is a widely-accepted and available tool that can be used to "estimate[] the monetized climate change damage associated with an incremental increase in [carbon dioxide] emissions in a given year." 499 FERC need only multiply the quantity of greenhouse gas emissions it attributes to a project by the Social Cost of Carbon to arrive at a monetized value of climate damages that can be directly incorporated into its economic test.

The more difficult analytical task is to calculate the quantity of greenhouse gas emissions that are attributable to a project. However, economic tools are available to facilitate this analysis. FERC already calculates the direct greenhouse gas emissions anticipated from pipeline construction and operation as part of the EA or EIS that it issues for a project.500 Models such as ICF's Gas Market Model and EIA's NEMS can facilitate a more sophisticated quantification of greenhouse gas emissions by calculating the additional combustion of natural gas caused by new pipeline infrastructure. These models can be integrated with models of the electric system,501 which allows FERC to calculate how the addition of natural gas in a regional market will lead to substitution of other resources such as coal-fired power generation or renewable generation. Evaluating resource substitution can enable a more sophisticated analysis of how new gas infrastructure will change net greenhouse gas emissions. Those net changes in greenhouse gas emissions can then be monetized using the Social Cost of Carbon.

\section{CONCLUSION}

The energy sector is in a period of significant transition, spurred by technological changes and growing concern about the significant contribution of energy use and production on global

499 PennEast Pipeline Co., 164 FERC ๆ 61,098, at P 122 n.274 (2018).

500 E.g., Spire STL Certificate Order, supra note 377, at P 246 (discussing direct emissions that were disclosed in the project's EA).

501 NEMS is an integrated model. See EIA, ANNUAL ENERGY OUTLOOK, supra note 493, at E-1. ICF's Gas Market Model can be integrated with its power sector model IPM. See TONGUE RIVER, supra note 492, at C.5-15 (describing the interaction between the Gas Market Model and IPM). 
climate change. This transition has significantly increased public attention on the energy sector and its regulators and, as a result, FERC now faces substantial attention and scrutiny from the public, press, and lawmakers.502 That attention will only increase as FERC embraces its critical role in facilitating, rather than merely observing (or obstructing), the energy system's transition to one that is cleaner and more flexible, while maintaining the system's affordability and reliability. 503

In managing that transition, a successful FERC would balance competing interests, clearly explain its choices, and act in ways that make the American people better off. Cost-benefit analysis can help FERC meet each of these objectives. Particularly given the growing demand from the courts and the executive branch that agencies fully consider the costs and benefits of their actions, now is the time for FERC to embrace cost-benefit analysis.

This Article has explored the potential for cost-benefit analysis to inform two areas of significant FERC responsibility relevant to the energy transition: RTO market rules and natural gas pipeline certificates. FERC is well within its legal authority to adopt cost-benefit analysis, including the quantification of a broad scope of costs and benefits (including environmental and climate consequences), and to use the results of that evaluation in deciding how to proceed with the issuance of new regulations, approval of RTO market rule changes, and certification of new natural gas infrastructure.

As the energy sector evolves, so too must FERC. To fulfill its role in an efficient, reasoned, and transparent manner, FERC is in need of sound analytical tools to balance competing interests in an increasingly complex regulatory landscape. FERC should join the cost-benefit state by adopting the analytical and decision making tool that has worked well for agencies across the federal government.

502 Summary of Written Testimony of FERC Comm'r Richard Glick Before the Subcomm. on Energy, H. Energy and Commerce Comm., 116th Cong. (June 12, 2019), https://www.ferc.gov/CalendarFiles/20190612103223-glick-testimony-06-12-19.pdf [https://perma.cc/3V95-CD96]; Amy Harder, Energy Regulators Divided Over Natural Gas and Climate Change, AxIOS (July 22, 2019), https://www.axios.com/ferc-natural-gasclimate-change-pipelines-emissions-d9357958-1aa8-4195-a6e2-582ba1a09ffo.html [https://perma.cc/K45Z-RFXP].

503 See Glick \& Christiansen, supra note 19, at 5. 